Raimundo Novaes Alencar Jr

\title{
O REPERTÓRIO ACÚSTICO DE UM ESPECIALISTA DE ROCHEDOS DA CAATINGA, O MOCÓ
}

(Versão corrigida)

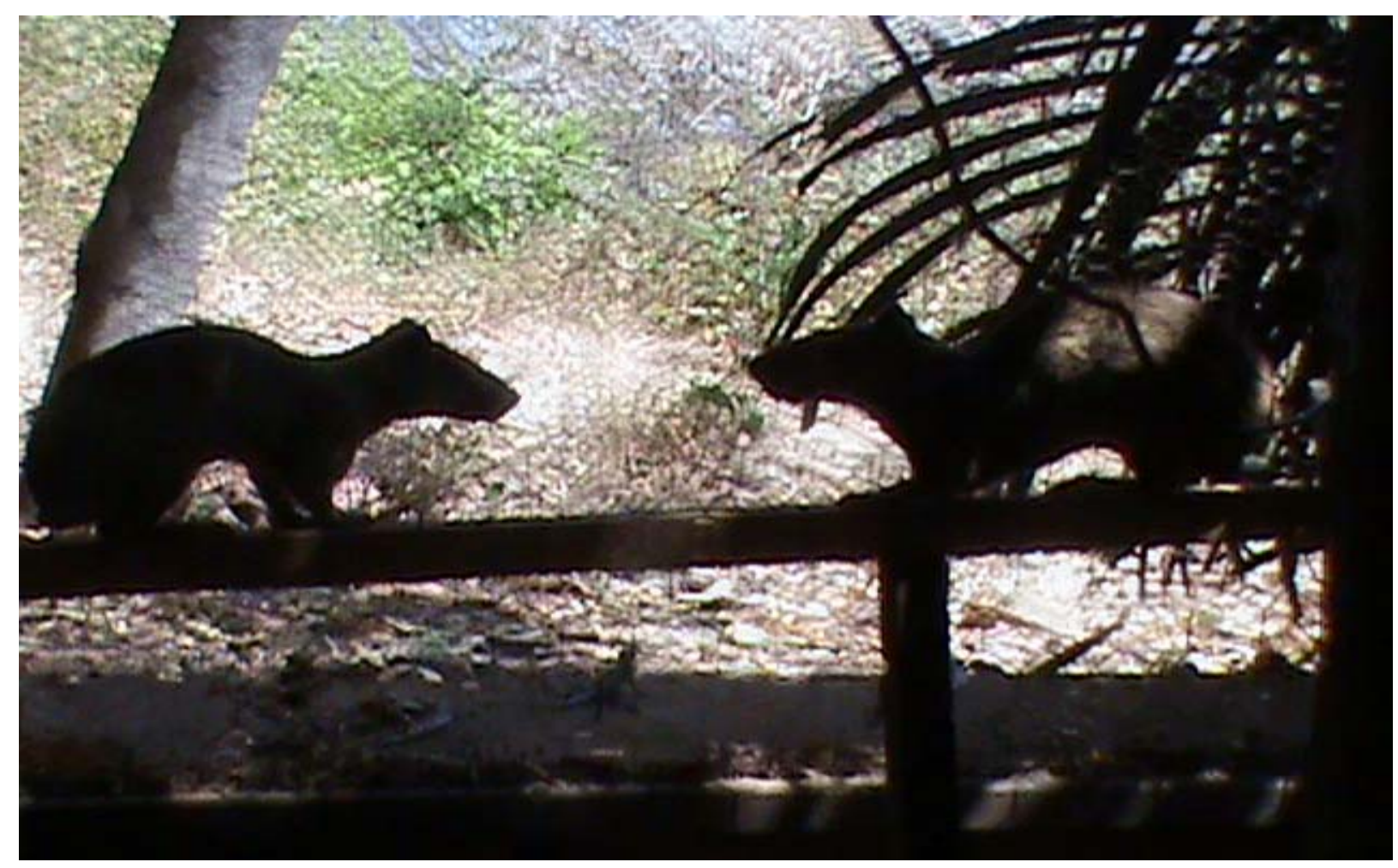

São Paulo

2011 


\title{
O REPERTÓRIO ACÚSTICO DE UM ESPECIALISTA DE ROCHEDOS DA CAATINGA, O MOCÓ
}

(Versão corrigida)

\author{
Dissertação apresentada ao Instituto de Psicologia da \\ Universidade de São Paulo, como parte dos requisitos \\ para a obtenção do título de Mestre em Psicologia. \\ Área deConcentração: Psicologia Experimental \\ (Etologia)
}

Orientador: Patrícia Ferreira Monticelli

\section{São Paulo}


AUTORIZO A REPRODUÇÃO E DIVULGAÇÃO TOTAL OU PARCIAL DESTE TRABALHO, POR QUALQUER MEIO CONVENCIONAL OU ELETRÔNICO, PARA FINS DE ESTUDO E PESQUISA, DESDE QUE CITADA A FONTE.

Catalogação na publicação

Biblioteca Dante Moreira Leite

Instituto de Psicologia da Universidade de São Paulo

Alencar Junior, Raimundo Novaes.

0 repertório acústico de um especialista de rochedos da caatinga, o Mocó / Raimundo Novaes Alencar Junior; orientadora Patricia Ferreira Monticelli. -- São Paulo, 2011.

$103 \mathrm{f}$.

Dissertação (Mestrado - Programa de Pós-Graduação em Psicologia. Área de Concentração: Psicologia Experimental) Instituto de Psicologia da Universidade de São Paulo.

1. Comportamento animal 2. Bioacústica 3. Caviinae_ 4. Kerodon rupestris 5 . Roedors de rochedos 6 . Semi-árido I. Título.

QL751 
FOLHA DE APROVAÇÃO

\title{
RAIMUNDO NOVAES ALENCAR JR \\ O REPERTÓRIO ACÚSTICO DE UM ESPECIALISTA DE ROCHEDOS DA \\ CAATINGA, O MOCÓ.
}

\begin{abstract}
Dissertação apresentada ao Instituto de Psicologia da Universidade de São Paulo, como parte dos requisitos para abtenção do título de Mestre em Psicologia.
\end{abstract}

Tese defendida e aprovada em _/_/_

BANCA EXAMINADORA

$\operatorname{Prof}(\mathrm{a}) \operatorname{Dr}(\mathrm{a})$

Instituição Assinatura

Prof(a) Dr(a)

Instituição Assinatura

$\operatorname{Prof}(\mathrm{a}) \operatorname{Dr}(\mathrm{a})$

Instituição Assinatura 
À Marilsa Machado, à Luzia Alencar e ao Kerodon rupestris 


\section{AGRADECIMENTOS}

À minha orientadora Patrícia F. Monticelli-Almada, que nesses anos mais do que uma orientadora foi uma amiga que brigou junto, lutou pelo sucesso da pesquisa, pelas viagens, vibrou com as conquistas, chamou a atenção aos equívocos, cobrou o rigor necessário a um cientista e mais do que tudo me deu o voto de confiança e acreditou que eu poderia fazer este trabalho que aqui se apresenta. Muito obrigado.

À minha querida companheira Isa, que entendeu as ausências, às vezes longas. Por ter compreendido que a produção de uma dissertação de mestrado provoca eventuais dentadas, mas que também produz vitórias, sorrisos e orgulho.

À minha família e especialmente a minha mãe que teve a paciência de entender as ausências que o trabalho intelectual por vezes produz e absorver as mordidas que o final de uma dissertação gera (rsrs), aos meus irmãos, Tota, Nem e Ninho, pelo apoio.

À família Machado que agora é também minha família.

À minha querida amiga Andrea Freixeda e à Biofauna pelo apoio e crenças.

Ao Prof. César Ades, pelos sempre prazerosos encontros, fossem nos caminhos entre os blocos do Instituto de Psicologia, nos congressos ou ainda nos aeroportos, regados de conversas sempre instigantes sobre as origens dos comportamentos e seus mecanismos, pois um aluno que inicia uma conversa com o Cesar, nunca sairá o mesmo depois do ultimo ponto. Sem esquecer aqui do uso de seu laboratório (você faz muita falta Cesar).

À Profa. Miriam G. Mijares pela amizade, pelos conselhos e pelo "empurrão" que me trouxe até essa dissertação.

Ao Pierre Landolt, proprietário da Fazenda Tamanduá, pela minha hospedagem e a dos mocós, pela ajuda financeira e por todo apoio à pesquisa. 
Ao Sr. Francisco de Assis e sua esposa, proprietários do Sitio em São Mamede, que nos receberam tão carinhosamente e nos ajudaram tanto nas capturas dos animais.

Aos funcionários da Fazenda Tamanduá, Célia, Silvania, Ocione, Manuel, Cleiton, Flavio, Marisa, Roberto, Wegidon, Rodão, Roberto, Totonho e sua esposa e outros tantos que peço que me desculpem por não ter colocado o nome aqui.

Especial agradecimento ao Jorge que ficou comigo no dia-a-dia do trabalho de campo, montando armadilhas, transportando animais, ajudando na manutenção das colônias, enfim, um providencial "braço direito". À sua esposa e filhos, Jorge, Josi e em especial a Cleide que me salvou tantas vezes das dores do nervo ciático.

À minha tia Ivonete e minha prima Tais, pelos ouvidos sempre interessado em entender o que eu estava fazendo.

Às amigas de Laboratório, Aline, Deborah, Clara, Bianca, Elisa, Nina (pela ajuda com textos), Natália (que orgulho!!!! Rsrsr e pela força na revisão do resumo né !!).

Aos amigos de USP, Rafael, Ariene, Heloísa, Marcelo e Vivi (agora em São Carlos), Fernanda e Ana.

Aos funcionários da Biblioteca - IPUSP, em especial a Célia e Lilian, que muito me ajudaram na reta final deste trabalho.

Aos funcionários da USP, Sônia (sem ela a coisa não anda), Ana Laura, Alexandre(s) e Gisele e Wilma.

À Milena da Unicamp pela ajuda e à Janine da UESC pela troca de material.

Ao Prof. Felipe Toledo (UNICAMP), pela ajuda com algumas definições que deveria usar na dissertação e pelo curso de bioacústica.

À Dra. Selene Nogueira, pelos encontros em congressos regados a toques e conselhos sempre providenciais. 
Às Profas. Patrícia Izar e Maria Luisa da Silva, pelas rigorosas observações no exame de qualificação.

Aos meus especiais amigos, Poronga, Ded, Estevo e Guilberter, pela amizade sincera, pelo apoio, ajuda (principalmente com as imagens) e por simplesmente serem quem são.

À família Teixeira Lima, por compreender tão bem o meu respeito aos animais (e botem nome nas galinhas).

Aos professores Fernando Leite, Vera Bussab e Emma Otta, que ministraram o curso de seminários em etologia que tanto contribuiu com o projeto.

Aos mocós que tiveram paciência comigo durante a fase de coleta de dados.

A todos que contribuíram direta ou indiretamente na produção desse trabalho.

À Universidade de São Paulo por acreditar no projeto.

Ao CNPq pela bolsa de pesquisa. 
"Veja bem, nosso caso é uma porta entreaberta e eu busquei a palavra mais certa, vê se entende o meu grito de alerta."

Gonzaguinha 


\section{RESUMO}

Alencar - Jr, R. N. (2011). O repertório acústico de um especialista de rochedos da caatinga, o Mocó. Dissertação de Mestrado, Instituto de Psicologia, Universidade de São Paulo, São Paulo.

A Caatinga é um ecossistema brasileiro análogo as savanas africanas apresentando escassez de chuvas e temperaturas altas. 0 mocó apresenta, importantes adaptações ao micro-ambiente dos afloramentos rochosos. Esse roedor caviomorfo, abandonou o hábito pastador comum a outros roedores cavíneos, como preá e a capivara, pela capacidade de escalar árvores e se alimentar de folhas e frutos. Alongou o período de gestação e adotou o cuidado paterno. Interessados em entender de que forma a comunicação acústica teria se ajustado ao ambiente isolado dos rochedos da caatinga, gravamos e analisamos as emissões sonoras dos mocós. Foram 90 dias de trabalho de campo nas Fazendas Tamanduá e São Francisco, na cidade de Patos, Paraíba. Capturamos 13 animais (6 machos e 7 fêmeas) e fizemos registros em áudio e vídeo em três situações: 1) pareamentos em caixa teste, nas condições macho $\mathrm{x}$ macho, macho $\mathrm{x}$ fêmea e fêmea $\mathrm{x}$ fêmea, 2) animais em grupo em cativeiro, e 3) animais em vida livre. Encontramos um repertório de 11 sinais sonoros, registrados em 3 categorias amplas de comportamento: (1) Exploração/Forrageamento: Có de contato, Estalido, Chorinho e Drrr; (2) Alerta: Assobio de alarme, Drrr e Silvo; (3) Interação Agonística: Ganido, Grito, Ronco, Arfar, Assobio de alarme e o Bater-dedentes. 0 repertório mostrou-se mais rico do que o de outros caviomorfos, como o preá. Discutimos esse resultado em relação ao tipo de vida social da espécie em comparação com a de outros caviníneos e à vida nos rochedos da caatinga. Também sugerimos que o Assobio de alarme seja um comportamento compartilhado entre o mocó e outras espécies de roedores 
de rochedos. Há uma perspectiva de continuidade da pesquisa em busca de uma maior compreensão da função biológica desse sinal e da riqueza desse repertório acústico.

Palavras-chaves: Bioacústica, Caviinae, Comportamento Animal, Kerodon rupestris, Roedores de rochedos, Semi-árido. 


\begin{abstract}
Alencar-Jr, R. N. (2011). The acoustic repertoire of a specialist of caatinga rockpiles, the rocky cavy. Dissertação de Mestrado, Instituto de Psicologia, Universidade de São Paulo, São Paulo.
\end{abstract}

The environment of Brazilian Caatinga ecosystem is similar to African Savannah with low level of rain and high temperature. The Moco shows important adaptation at the micro-environment of rock outcrops. This caviomorph rodent abandoned grazing habit, commom at others Caviinae species such as the Cavy and the Capybara for the capacity of climbing trees feeding of leaves and fruits. It also lengthened the gestation period and adopted paternal care. Interested in understanding how acoustic communication would have adjusted to the isolated environment of Caatinga rock piles, we recorded and analyzed the signals songs of Moco. Past through 90 days in field at Fazenda Tamanduá and Sítio São Francisco located at Patos city Paraiba State in Brazil. We captured 13 animals (6 males and 7 females), acquired audio and video of animals in three different situations: 1) paired in tests boxes under conditions: male $\mathrm{x}$ male, female $\mathrm{x}$ male and female $x$ female; 2) captivity group and 3) Living free. We found a repertoire with 11 acoustic signals registered in 3 broad behavioral categories: (1) Exploration/ Foraging: Contact call, Co, Clicking (Estalido), Whine (Chorinho) and Drrr call, (2) Warning: Alarm whistle, Drrr call and Silvo, (3) Agonistic Interaction: yelp (Ganido), scream (Grito), grunt (Ronco), a breathless like sound (Arfar), Alarm Whistle and Tooth-Chatter. This repertoire showed more rich that other caviomorph as a cavy. eu escreveria esse parágrafo dessa forma: This repertoire seemed better than other caviomorph as a Cavy. We discussed those results comparing the social life of species with social life of others Caviinae and the life at the rock piles of Caatinga. We also suggested that the Alarm whistle is shared between the 
Moco and others rock rodents. There is a perspective to continue this research looking for a better comprehension of the biologic function of this signal and acoustic repertoire richness.

Key words: Animal Behavior, Bioacoustics, Caviinae, Kerodon rupestris, rockdwelling rodents, Semi-arid. 


\section{SUMÁRIO}

Resumo, 9

Abstract, 11

Lista de Figuras, 15

Lista de Tabelas, 20

1. Introdução, 22

1.1 A Bioacústica, 22

1.2 O Mocó, 24

1.3 Comportamento social e acústico, 28

Objetivos, 33

2. Materiais e Métodos, 34

2.1 Área de Estudo, 34

2.2 Captura e Identificação, 36

2.3 Recinto e grupo de estudos, 39

2.4 Coleta de dados acústicos e comportamentais, 40

2.5 Soltura dos animais, 47

2.6 Análise dos dados, 48

2.7 Equipamento de registro, 51

3. Resultados, 52

3.1 Dados morfométricos, 52

3.2 Repertório acústico e comportamental: tipos de sinais e contexto de emissão, 52

3.3 Descrição e caracterização estrutural dos sinais sonoros, 56

3.3.1 Chorinho, 57

3.3.2 Drrr, 60

3.3.3 Estalido, 61

3.3.4 Assobio de Alarme, 63

3.3.5 Ganido, 64

3.3.6 Grito, 68 
3.3.7 Arfar, 68

3.3.8 Có, 71

3.3.9 Ronco, 71

3.3.10 Silvo, 74

3.3.11 Bater-de-dentes, 75

3.4 Outros chamados, 77

4. Discussão, 79

5. Referências Bibliográficas, 98 


\section{LISTA DE FIGURAS}

Figura 1: Limites da Província Fitogeográfica das Caatingas tal como foi caracterizada em Prado (2005). O território das Caatingas (à esquerda) coincide aproximadamente ao Polígono das Secas (à direita). Compõe-se de um mosaico de vegetações pelos estados do Ceará, Rio Grande do Norte, a maior parte da Paraíba e de Pernambuco, o sudeste do Piauí, oeste de Alagoas e Sergipe, região norte e central da Bahia, uma faixa de Minas Gerais (entorno do Rio São Francisco), um enclave na região média do Rio Jequitinhonha e a ilha de Fernando de Noronha

Figura 2: Esquema representativo das relações filogenéticas de Cavioidea, segundo a revisão atual (Woods \& Kilpatrick 2005). Nela, o mocó (Kerodon) não pertence mais a Caviinae, dos preás e da cobaia; forma com as capivaras (Hydrochoerus) a nova subfamília de Caviidae, Hydrochoerinae, tornando-a parafilética. Adaptado de Malange (2009).

Figura 3: Localização da Fazenda Tamanduá (circulo amarelo), a principal área de estudo de mocós localizado entre os municípios de Pato e Santa Terezinha e localização do Sitio Francisco de Assis (círculo vermelho) local de captura do maior número de mocós localizado no município São Mamede, ambos pertencentes ao estado da Paraíba Brasil.

Figura 4: Armadilha do tipo pitfall usada para a captura de mocós (a) quando armada, com alimento sobre a tampa, usado como ceva para a atração de mocós e (b) simulando o movimento da tampa quando a armadilha era ativada pelo peso de um animal. 
Figura 5: Caixa de transporte e marcação de animais. (a) Caixa utilizada para o transporte individual dos animais. (b) Parte posterior do corpo de um mocó macho exibindo a mancha na cabeça (seta) produzida com uso de descolorante de pêlos para a marcação individual dos animais capturados, antes de serem introduzidos no cercado.

Figura 6: (a) Vista frontal do cativeiro que abrigou o grupo de mocós formado por 13 indivíduos capturados na Fazenda Tamanduá e no sitio Francisco de Assis; (b) Vista frontal da parte externa do cativeiro, sendo do lado direito a abertura (porta) que levava ao interior do recinto e no lado esquerdo da foto observa-se a forragem feita com palha de coqueiro, para o melhor conforto térmico dos animais e (c) Mocó utilizando o tronco que foi colocado dentro do recinto para preservar o hábito de escalar dos animais.

Figura 7: Condição experimental de pareamento de animais. (a) Vista frontal da caixa-teste utilizada nos pareamentos com o microfone posicionado no pedestal de madeira confeccionado para uso como suporte do microfone; (b) uma sessão, em andamento, de pareamento entre dois machos, com tecido revestindo o fundo da caixa e (c) anteparo de madeira por nós confeccionado e utilizado para que os animais não tivessem contato visual com o pesquisador, no canto inferior esquerdo, duas caixas de transporte individual de animais.

Figura 8: Animais em grupo no cativeiro: (a) três animais adultos no cercado dentro do recinto que nos foi cedido (Joana ao fundo, e outros dois indivíduos não identificados pela foto), e (b) visão mais ampla dos animais no cercado, um deles usando o tronco introduzido para esse fim. Todos os animais estão em postura de alerta, com os olhos dirigidos para um mesmo local, fora do recinto.

Figura 9: Condição de registro dos animais em vida livre. (a) Posição do microfone nos registros feitos no rochedo da Fazenda Tamanduá, apoiado no suporte de madeira; (b) um mocó no topo do rochedo, em 
postura de vigilância, no posto de observação, o local mais comum para a adoção de postura de vigilância e no qual os animais se revezavam, e (c) um mocó em uma fenda entre as rochas que lhes servia como abrigo na Fazenda Tamanduá, na área onde foram soltos ao término da viagem de coleta de dados.

Figura 10: Sonograma de uma frase de Chorinho de menos de $4 \mathrm{~s}$, composta por 11 notas (retângulos verdes numerados) de contornos (modulação de frequência) variados, e ocupando a faixa de 1 a $8 \mathrm{kHz}$. É possível que haja dois animais vocalizando ao mesmo tempo, o que pode ter levado as notas 5 e 6 ficarem sem intervalo de tempo.

Figura 11: Três Sonogramas de uma frase de Drrr. (a) Frase com 4 notas (retângulo verde) ocupando faixa de frequência de 0,3 a 1,5kHz. (b) Frase com 4 notas (retângulo verde) ocupando faixa de frequência entre 0,2 e 1,3kHz. (c) Frases com 4 notas (retângulo verde) ocupando faixa de frequência entre 0,1 e $1,2 \mathrm{kHz}$ e configurada em Sampling Frequency 8kHz.

Figura 12: Sonograma de Estalido apresentando frase de 3,2 segundos com 12 notas ocupando faixa de frequência entre 0,5 e $19 \mathrm{kHz}$, sendo cada nota possuindo faixa de frequência própria.

Figura 13: Três sonogramas do Assobio de alerta. (a) Frase curta de 6 notas na faixa de $1,5 \mathrm{kHz}$ e $6 \mathrm{kHz}$. (b) Recorte de 4 notas (2s) da sequência mostrada em (c), aumentada 4 vezes para mostrar as notas em detalhe. (c) Frase de 10 segundo com 22 notas. 0 retângulo vermelho mostra uma vocalização de uma ave entre a vocalização do mocó.

Figura 14: Sonogramas de Ganidos emitidos (a) PA: frase com 4 notas (retângulos verdes) estruturalmente variáveis de até $14 \mathrm{kHz}$. 0 retângulo vermelho mostra a semelhança entre o final da nota 2 com a nota 3 e (b) GR: frase com 3 notas (retângulos verdes) também de estrutura variável, a primeira, com faixa de frequência maior, atingindo os $14 \mathrm{kHz}$. Os retângulos vermelhos de número 5 mostram 
um elemento característica do ganido que pode ser emitido como uma nota isolada (3, em a) ou como partes finais de outras notas (final de 2 em a, e final de 1 em b); sua estrutura é de um estacato, isto é, uma sequência de Us invertidos sem intervalo.

Figura 15: Sonograma de frases de Grito. (a) 3 notas (retângulos verdes enumerados) emitidas pelo macho Beto quando pareado com Manuel.

(b) Frase de 3 notas (marcamos apenas a 3a delas), emitida após Chorinho por uma fêmea pareada com outra fêmea. Nota-se o Arfar da fêmea agressora sobrepondo-se às vocalizações da agredida.

Figura 16: Sonograma de Arfar. (a) representação de frase de aproximadamente 15 segundos apresentando seis notas (colunas mais escuras dentro do retângulo verde). (b) Sequencia mista de Ganido, Chorinho e Arfar.

Figura 17: Sonogramas de Có. (a) frase de có (retângulos verdes 1-4) 2, 5 e 6 transição para chorinho. (B) Có (retângulos enumerados de 1, 2 e 3), 4 e 5 são vocalizações de outros animais sobrepondo-se com o Có. (c) 5 frases de chorinho sendo o retângulo 1 mostrando frase composta por 4 notas e os demais com frase de 2 notas. (d) os retângulos pares mostram vocalização Có e os impares mostram o Chorinho emitidos por outros animais do GR.

Figura 18: Sonograma de Ronco com 0,5 segundo de duração. (a) representação de 1 nota ocupando faixa de frequência de $0,3-9,5 \mathrm{kHz}$. (b) Representação da mesma nota com menor grau de ruído de fundo.

Figura 19: Sonograma de Silvo de 23 segundos apresentando um surto com 3 frases com um par de notas (retângulos verdes numerados) cada. As notas tem duração aproximada de 2 segundos (cada), ocupando faixa de frequência de 6 a $8 \mathrm{kHz}$.

Figura 20: Sonograma de entrechoque de incisivos. (a) PA: Frase de 2 segundos apresentando 21 notas (retângulos verdes numerados) ocupando faixa de frequência de 0,5 a $21,5 \mathrm{kHz}$ e (b) VL: frase de 2 
segundos apresentando 17 notas (retângulos verdes numerados) ocupando faixa de frequência $0,5 \mathrm{a} 12 \mathrm{kHz}$.

Figura 21: Sonograma de Tamborilar: (a) Frase de Tamborilar composta por três notas (retângulos vedes numerados). (b) Frase com três notas do tamborilar representadas em três colunas com intervalos muito curtos. 


\section{LISTA DE TABELAS}

Tabela 1: Distribuição em número de dias e tempo total investidos na coleta de emissões acústicas de mocós, em cada situação de registro: pareamento (PA), animais em grupo no cativeiro (GR) e animais em vida livre (VL). Os Valores entre parêntesis representam os valores parciais das condições MM, MF e FF de PA, e a Fazenda Tamanduá (FT) e o sitio São Francisco (SF) de VL.

Tabela 2: Animais que participaram de cada sessão de pareamento, por condição experimental. A ordem dos pares e das condições MM, MF e FF na tabela refletem a ordem em que foram realizadas as sessões.

Tabela 3: Configuração dos parâmetros analisados dentro do programa Raven 1.4 para cada sinal sonoro encontrado no repertório do mocó.

Tabela 4: Medidas morfométricas dos animais capturados, por sexo $(n=7$ fêmea, 6 machos). As medidas estão representadas pelos seus valores médios, desvios-padrão (entre parêntesis) e mínimos e máximos.

Tabela 5: Repertório total e proporção de sinais sonoros diferentes obtidos em cada situação de coleta: nos Pareamentos (PA: MM, MF e FF), animais em grupo em cativeiro (GR) e animais em vida livre (VL) nas duas localidades, sitio São Francisco e Fazenda Tamanduá (SF e FT).

Tabela 6: Contexto geral de emissão dos sinais. Para cada categoria ampla de comportamento, a ocorrência dos sinais está indicada por $\mathrm{x}$, para as situações de coleta em grupo (GR) e em vida livre (VL). Para os pareamentos, que envolveram coletas sistemáticas de dados, apresentamos o número de sessões (entre parêntesis, o número de surtos) em que as emissões foram registradas. 
Tabela 7: A estrutura física dos 11 sinais que compõe o repertorio da espécie $K$. ruspestris. As medidas estão representadas pelos seus valores médios, desvios-padrão (entre parêntesis) e mínimos e máximos. 0 número de notas usadas para a descrição dos sinais é apresentado na ultima coluna. Dados adicionais sobre a amostra de surtos e de sessões das quais foram extraídas essas notas estão no anexo 1.

Tabela 8: A estrutura física do Assobio de alarme de $K$. ruspestris emitido nas três condições de coletas. As medidas estão representadas pela média (desvio-padrão) e mínimo-máximo. Apresenta-se também o número amostral $(\mathrm{N})$ de notas usadas para essa descrição. A duração está expressa em segundos e as medidas de frequência em kHz.

Tabela 9: Comparação entre os repertórios do mocó (Kerodon rupestris) e dos cavídeos $H$. hydrochaeris (capivara), G. spixii (preá-de-denteamarelo da caatinga), C. aperea (preá de maior distribuição geográfica) e C. porcellus (cobaia doméstica). Na comparação, consideramos primeiro o contexto de emissão e depois a estrutura geral do sinal. Os nomes originais da literatura consultada estão entre parêntesis, assim como outros comentários. Pontos de interrogação indicam comparações que ainda merecem ser analisadas em mais detalhe. $(*)$ indica que o assobio-ao-tratador, exclusivo da espécie domesticada, não está embutido no total de sinais do repertório de Cavia. 


\section{1- INTRODUÇÃo}

\subsection{A Bioacústica}

No mundo animal, os sinais acústicos são uma importante ferramenta de comunicação quando outros canais não são eficientes. É o caso da comunicação em um ambiente com pouca luminosidade, quando os sinais visuais dificilmente são recebidos, ou quando a distância física entre os participantes impossibilita a captação de sinais químicos, relativamente simples e universais (Grier \& Burk 1992). Os sinais acústicos oferecem três dimensões de variação - temporal, espectral e de intensidade - o que os torna ricos em termos do número de mensagens distintas que podem comportar, viabilizando a complexidade das relações nos grupos sociais (Gros-Louis et al. 2008; Hailman \& Ficken 1996; Hsu et al. 2005; Monticelli 2005).

O estudo da comunicação animal por sinais sonoros deu os seus primeiros passos após os avanços tecnológicos decorrentes da Segunda Guerra Mundial (Vielliard 1987; Vielliard 1997). Batizado com o nome de "Bioacústica" estabeleceu-se como importante ferramenta de pesquisa a partir da década de 60, pelos ornitólogos (Vielliard 1987; Vielliard 1997; Vielliard \& Silva 2010). Foi aos poucos conquistando um número cada vez maior de pesquisadores de áreas afins. Entre seus atrativos estão seu baixo custo relativo e ser um método não-invasivo e à distância de coleta de informações biológicas (sinais acústicos) úteis para identificação de espécies, inferências de relações filogenéticas ou para a simples produção de conhecimento básico sobre as espécies (Vielliard 1987; Vielliard 1997; Vielliard \& Silva 2011).

Foi através do canto de Andropadus virens, um pássaro da África Central, que Slabbekoorn \& Smith (2002) identificaram um processo de 
especiação em andamento. Eles notaram que indivíduos de populações geograficamente distintas, uma de borda de savana e outra de floresta tropical, não reconheciam o canto uns dos outros. De modo semelhante, Toledo et al. (2007) identificaram uma nova espécie de anuro, que chamaram de Sphaenorhinchus caramaschi, com base em parâmetros do seu canto, significativamente diferente de $S$. surdus, até então considerada única espécie do gênero.

Em peixes do gênero Cyprinella, o conhecimento do repertório acústico foi útil para se testar a hipótese de que espécies proximamente relacionadas compartilhavam componentes de sinais ausentes em espécies filogeneticamente mais distantes, e na avaliação do grau de divergência entre elas (Phillips \& Johnston 2009). As espécies C. gibbsi e C. trichroistia, que tinham os repertórios mais semelhantes, agruparam-se mais proximamente em uma análise de cluster com base na similaridade do canto de corte.

Os sinais acústicos também podem servir para se descrever e interpretar processos ontogenéticos e variações motivacionais (Monticelli et al. 2003) e aspectos ecológicos e fisiológicos do comportamento de comunicação (Gros-Louis et al. 2008; Izar 1999; Mendes \& Ades 1995; Mendes \& Ades 2004; Monticelli 2005; Oliveira \& Ades 2004; Oliveira 2002; Vielliard 2004).

Qualquer uma dessas pesquisas, contudo, requer um conhecimento básico das espécies que pode ser produzido por estudos descritivos de repertórios acústicos em uma abordagem etológica. No caso do mocó Kerodon rupestris, a espécie brasileira escolhida para esta pesquisa, o conhecimento inicial e amplo sobre o seu comportamento de comunicação tem implicações na discussão sobre suas relações filogenéticas e origem evolutiva. Por ser uma das poucas espécies endêmicas da Caatinga (é uma das duas únicas espécies de mamíferos junto do Widomys pyrrhorhinus, um pequeno roedor da família Cricetidae) desse bioma, segundo Oliveira et al. 
2005), sua história evolutiva pode revelar aspectos importantes da própria origem do bioma.

\subsection{0 mocó}

O mocó é um pequeno mamífero do grupo dos roedores histricomorfos que produzem filhotes precoces e nos quais é comum a permanência do macho com a fêmea após a cópula (Kleiman 1974). 0 gênero possuía apenas uma espécie conhecida até a recente descrição de $K$. acrobata endêmica do domínio morfoclimático do Cerrado (Bezerra et al. 2010). Tanto na Caatinga como no Cerrado, Kerodon especializou-se aos micro-habitats mais mésicos oferecidos pelas formações rochosas - na Caatinga representados por afloramentos rochosos, morros de arenito e serras de rochas cristalinas pré-cambrianas (Mares et al. 1985). Ali, a vegetação encontra condições para manter-se verde durante todo o ano, oferecendo itens alimentares particulares, como folhas, botões de flores e casca de árvores (Lacher 1981; Sousa 2006). Para ter acesso a esses itens, o mocó parece ter desenvolvido estruturas anatômicas e habilidades motoras para escalar árvores e rochas, ausentes nas espécies de sua linhagem evolutiva (Lacher 1981).

\section{Suas relações filogenéticas}

$\mathrm{Na}$ classificação tradicional, o mocó é um membro da subfamília Caviinae dos preás e do porquinho-da-índia (Quintana 1998). A revisão taxonômica mais recente (Woods \& Kilpatrick 2005) propõe a inclusão das capivaras Hydrochoeris em Caviidae e a classificação como um táxon irmão de Kerodon (Hydrochoerinae, Figura 2), seguindo Rowe \& Honeycutt (2002). 

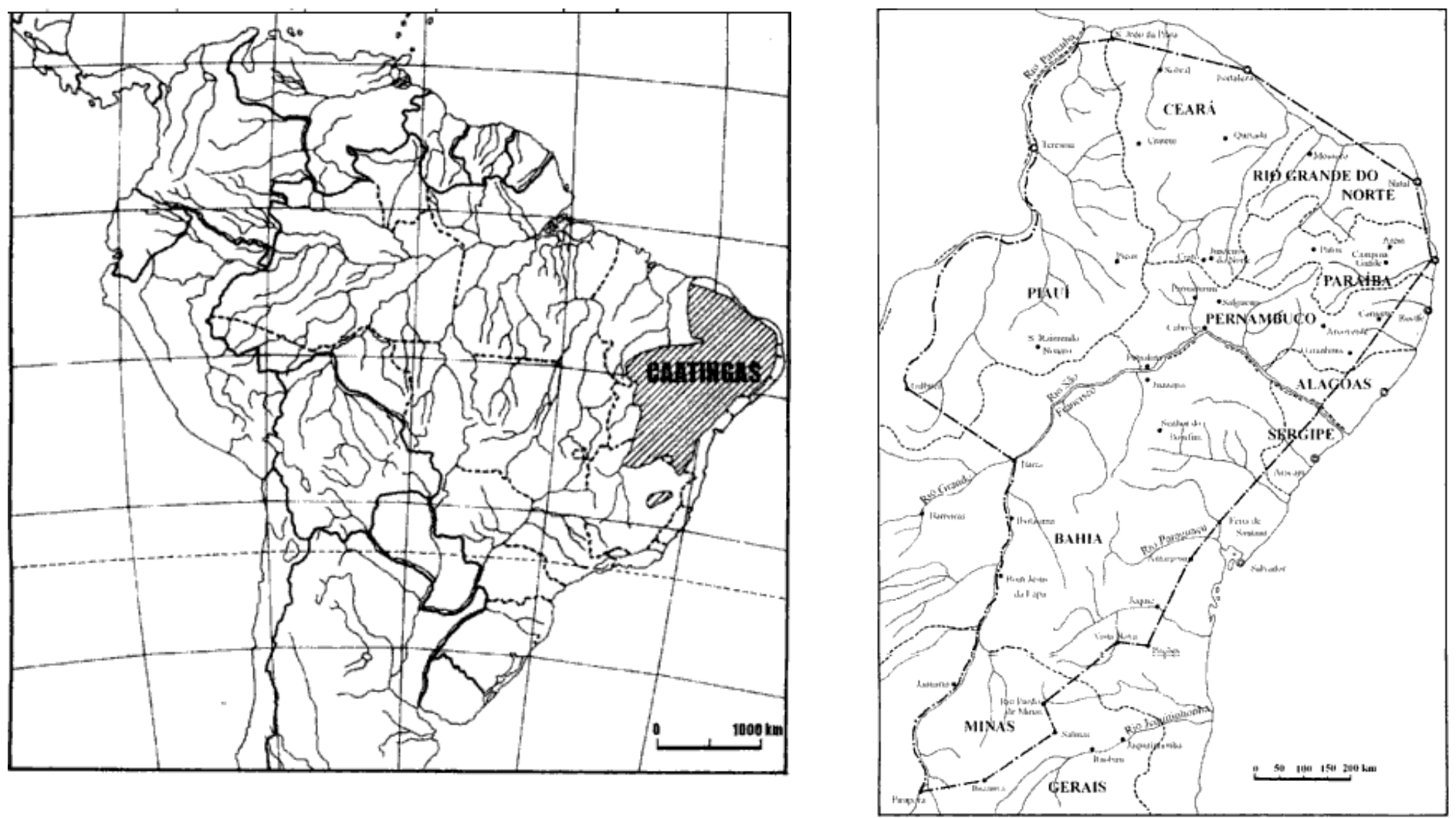

Figura 1: Limites da Província Fitogeográfica das Caatingas tal como foi caracterizada em Prado (2005). 0 território das Caatingas (à esquerda) coincide aproximadamente ao Polígono das Secas (à direita). Compõe-se de um mosaico de vegetações pelos estados do Ceará, Rio Grande do Norte, a maior parte da Paraíba e de Pernambuco, o sudeste do Piauí, oeste de Alagoas e Sergipe, região norte e central da Bahia, uma faixa de Minas Gerais (entorno do Rio São Francisco), um enclave na região média do Rio Jequitinhonha e a ilha de Fernando de Noronha. Mapas extraídos de Prado (2005). 
Passam a ser três as subfamílias de Caviidae (Rodentia: Caviidae: Hystricognathi; Woods 1993). Rowe \& Honeycutt (2002), contudo, haviam proposto também que capivaras e mocós formassem um clado monofilético com as maras: Dolichotis, Pediolagus, Kerodon, and Hydrochoeris.

Os três gêneros tradicionais de Caviinae, Cavia, Galea e Microcavia são mais parecidos entre si, em termos morfológicos, do que com Kerodon. Os três primeiros gêneros contém animais de hábito pastador com três dígitos nas patas dianteiras e quatro nas patas traseiras e todos com garras (Lacher 1981). Kerodon, além de ser maior e ter o focinho mais alongado, tem as patas traseiras e dianteiras acolchoadas e sem garras, o que pode estar associado ao hábito escalador. Tem ainda, em um dos dedos das patas traseiras, uma unha pontiaguda que usa para coçar o pelo (Lacher 1981). Essas modificações morfológicas de Kerodon são compartilhadas com outras espécies de mamíferos de ambiente rochoso ("rock-dwelling"), como o Heterohyrax brucei, Procavia johnstoni, Marmota flaviventris, M. caligata, entre outras distribuídas ao redor do mundo (Mares \& Lacher 1987).

As Cavias e as Galeas (Sousa 2006) são ainda mais semelhantes entre si. Distinguem-se pela coloração amarelada dos dentes e a presença de uma mancha branca ao redor dos olhos das espécies de Galea. Também são esses os gêneros de distribuição geográfica mais ampla (Dunnum \& Salazar-Bravo 2010; Ximénez 1980).

Cavia compõe-se de 4 espécies silvestres brasileiras e uma andina, e uma espécie domesticada, o porquinho-da-índia ou cobaia, C. porcellus (Figura 2; Cherem et al. 1999; Ximénez 1980). A espécie de maior distribuição é $C$. aperea que ocorre por toda a grande parte central da América do Sul; no outro extremo de distribuição, está $C$. intermedia, que se restringe a uma pequena ilhota do arquipélago Moleques do Sul, em Santa Catarina (Cherem et al. 1999).

0 gênero Galea Meyen, 1832 reúne quatro a seis espécies viventes (Bezerra 2008; Dunnum \& Salazar-Bravo 2010) popularmente chamadas de 
"preá", pelos habitantes da caatinga, ou de "preá-de-dente-amarelo" (do inglês yellow-toothed cavy). Há registros paleontológicos desde o pleistoceno inferior quando haviam outras duas espécies hoje extintas, G. ortodonta e G. tixisiensis (Bezerra 2008).

0 gênero Kerodon Wied, 1825, possui apenas duas espécies descritas, K. rupestris e K. acrobata (Lessa \& Pessoa 2005; Moojen et al. 1997). A primeira e mais conhecida foi encontrada em 32 municípios do nordeste brasileiro (Oliveira et al. 2005), desde o estado do Piauí até o norte de Minas Gerais (Lacher 1981; Roberts et al. 2008). Possui pelagem macia de coloração acinzentada, mesclando pelos pretos e amarelos e um contorno amarelo ferruginoso na parte externa das coxas (Lessa \& Pessoa 2005; Sousa 2006). K. acrobata tem pelagem mais escura, tem o corpo maior e o focinho é mais alongado (Moojen et al. 1997). Foi encontrada na região nordeste de Goiás e é possível que se distribua até o Tocantins (Lessa \& Pessoa 2005; Moojen et al. 1997).

Apesar da proximidade filogenética, essas espécies ocupam ambientes tão distintos quanto podem ser a Caatinga nordestina (Kerodon e Galea, Lacher 1981), áreas de pastagem e bordas de Mata Atlântica (Cavia aperea, C. magna e C. fulgida, Ximénez 1980) e um ambiente insular (Cavia intermedia, Cherem et al. 1999). Também verticalmente há espécies vivendo em regiões de altas altitudes (C. tschudii e M. australis) e outras, como a $C$. magna e C. intermedia em baixas altitudes. Tamanha diversidade pode revelar adaptações estruturais e comportamentais no grupo e embasar a discussão acerca da evolução do comportamento, incluindo o acústico, nosso foco de interesse.

A atual taxonomia (Woods e Kilpatrick 2005) aproxima os mocós das capivaras (Hydrochoerus hydrochaeris Linnaeus 1766), esse considerado o maior roedor vivente pode atingir $80 \mathrm{~kg}$ um roedor, é uma animal de hábito semi aquáticos e de ampla distribuição, ocorrendo desde matas ciliares a savanas inundáveis. As capivaras vivem em grupos grandes de até 25 
indivíduos com a presença de macho dominante e formação de harém (Herrera e MacDonald 1989).

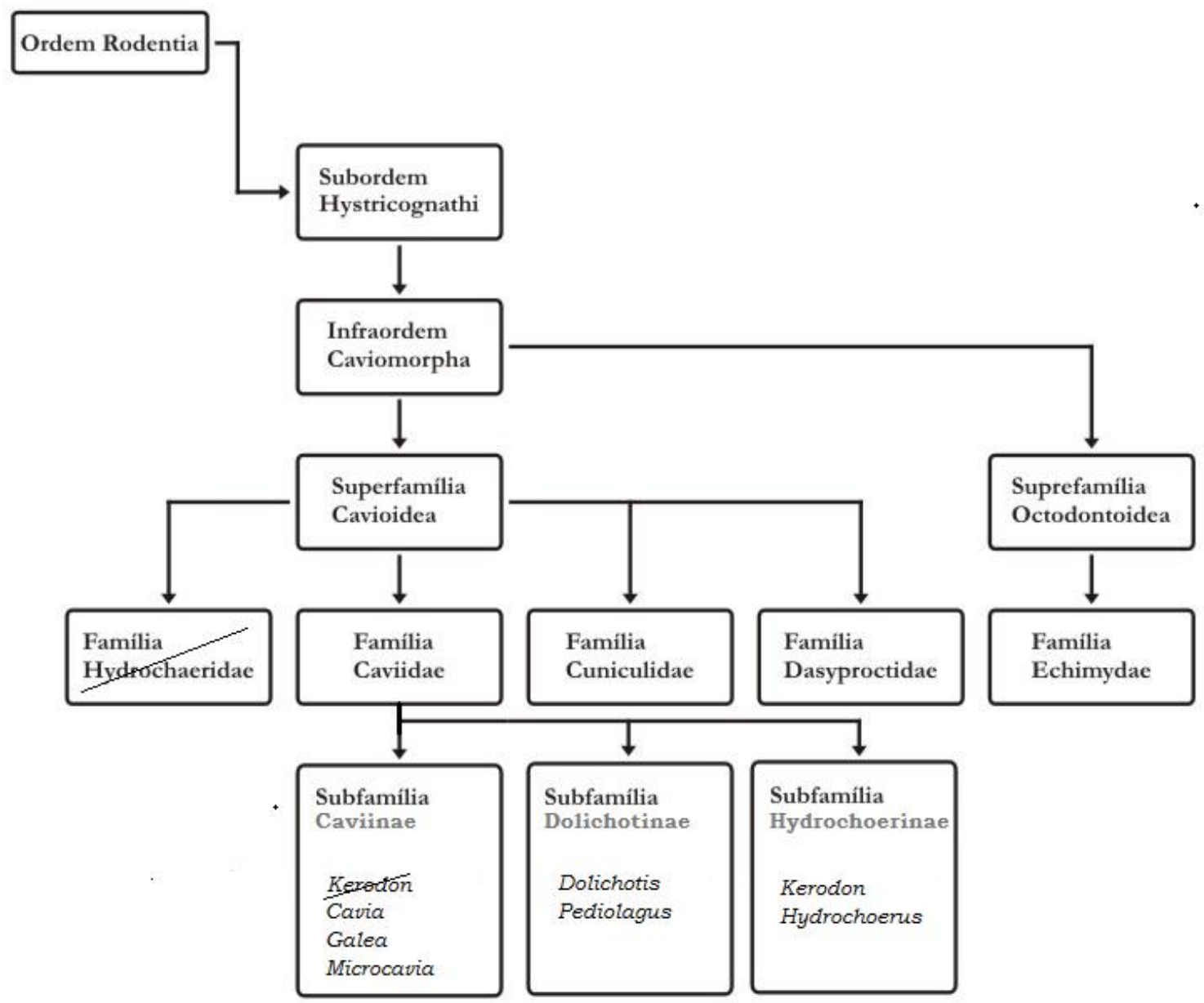

Figura 2: Esquema representativo das relações filogenéticas de Cavioidea, segundo a revisão atual (Woods \& Kilpatrick 2005). Nela, o mocó (Kerodon) não pertence mais a Caviinae, dos preás e da cobaia; forma com as capivaras (Hydrochoerus) a nova subfamília de Caviinae, Hydrochoerinae, tornando-a parafilética. Adaptado de Malange (2009).

\subsection{Comportamento social e acústico}

Rood (1972) preconizou que quanto maior a complexidade das relações sociais de uma espécie maior será o seu repertório sonoro. De acordo com Lacher (1981) determinados fatores ecológicos dentro do habitat, tais como a distribuição e produtividade desses recursos (abrigo, alimentação, viabilidade de fêmeas e machos para reprodução) e o risco de 
predação são primordiais para se estabelecer os laços sociais. Tanto Eisenberg (1974) como Lacher (1981) atribuem ao grau de distribuição dos recursos o nível de complexidade social e a riqueza do repertório acústico.

Há, na literatura de aves e primatas, táxons conhecidamente acústicos e bem estudados, exemplos que suportam essas hipóteses, como o anu branco e o macaco-prego. Fandiño-Mariño (1989) estudou a comunicação acústica no anu branco, Guira guira. Segundo o autor os grupos dessa espécie flutuam em torno de 14 indivíduos de diferentes faixas etárias e ambos os sexos. Embora não tenha sido seu objetivo descrever o comportamento da espécie, Fandiño-Mariño relatou uma grande gama de comportamentos sociais afilitivos e agonístico, intra-grupal, tanto como inter-grupal; havia hierarquia de dominância dentro do grupo e disputas por território entre grupos rivais envolvendo ataques e perseguições. Acompanhando esses comportamentos, o autor apontou 6 grandes categorias que rotulou como chamados de reconhecimento e (ou) agregação, chamados coesivos, chamados hostis, chamados de necessidade, chamados especiais e outros chamados. Foram identificadas 15 vocalizações distintas dentro dessas 6 categorias gerais.

Espécies de mamíferos altamente sociais também apresentam um repertório sonoro rico em número de categorias. Cebus capucinus apresenta um repertório de 27 sinais sonoros em ao menos 5 contextos comportamentais: comportamentos afiliativos, agonisticos, de coesão e movimentação, social e alarme (Gros-Louis et al. 2008). Os autores sugerem que futuras análises mais minuciosas possam revelar subcategorias dentro de cada uma dessas categorias, aumentando o repertório acústico da espécie. Novamente, esse repertório amplo está associado a um grupo grande de animais que exibem interações e relações sociais complexas envolvendo comportamentos de negociação social e alocuidado de filhotes, há relações de catação, formação de coalizões, organização de hierarquia de 
dominância formal linear e estável entre as fêmeas e transmissão de tradições culturais (Gros-Louis et al. 2008; Verderane 2010).

0 repertório acústico dessas espécies apresenta formas graduadas que se enquadram na categoria de Eisenberg (1974) dos sinais que desempenham funções comunicativas mais gerais: agem como indicadores de excitação e auxiliam na localização do emissor, como os chamados usados para a manutenção e regulação do contato durante forrageio.

A mesma relação pode ser observada em cavídeos. Há, de um lado, espécies consideradas pobres no plano vocal e socialmente pacíficas, como a Microcavia (Rood 1972), cujo repertório comporta apenas três sinais sonoros de comunicação; de outro lado, espécies com repertório comportamental mais amplo e estruturas sociais mais complexas, têm, ao contrário, um repertório rico em sinais sonoros, como a Cavia aperea (Monticelli \& Ades 2011; Monticelli \& Ades submetido) e a Hydrochoerus hydrochaeris (Barros et al. 2011; Herrera \& Macdonald 1989; Herrera \& Macdonald 1993).

C. aperea é uma espécie territorial que vive em grupos pequenos e poligínicos (um macho e até três fêmeas) (Asher et al. 2004; Asher \& Sachser 2001). Há machos satélite (pequenos ou jovens) que são importantes para a organização do grupo, participando da procura de alimento, defesa de território contra invasores e eventualmente copulam com as fêmeas do grupo (Asher et al. 2008). Para regular essa complexa rede de relações, a espécie usa 10 sinais acústicos que incluem bater-de-dentes, chamados de contato e chorinhos de estrutura bem variável, chamados de alerta para curta e longa distância, um chamado de corte, dentre outros.

Em capivaras (Hydrochoerus hydrochaeris), um roedor histricognata de tamanho grande que vive em grandes grupos (10 - 25 indivíduos) (Herrera \& Macdonald 1993), com marcada complexidade de comportamentos sociais, envolvendo relações de hierarquia lineares estabelecidas em encontros agonísticos com luta, indivíduos cumprindo 
funções sociais definidas dentro grupo e cuidado aloparental (Herrera \& Macdonald 1993; Barros et al 2011). 0 repertório sonoro desse roedor é constituído por 8 emissões sonoras, sendo uma não vocal (Barros, 2009; Barros et al, 2011). Essas emissões estão distribuídas em categorias funcionais de contato, alarme, separação e agonismo. Esses sinais sonoros são utilizados como mecanismos reguladores de interações sociais, como a de manter o grupo coeso durante o deslocamento por longas distâncias e alertar os membros do grupo sobre mudanças no ambiente, como aproximação de predadores ou de jovens desgarrados (Barros et al. 20110). Muito provavelmente novos sinais deverão ser descritos quando o comportamento de corte dessa espécie for registrado em populações de vida livre e provavelmente revelará um repertório acústico comparável ao descrito para Cavia aperea.

0 repertório acústico de $K$. rupestris foi descrito de forma simplificada e qualitativa e a partir de animais em cativeiro, por Lacher em 1981. Foi com base nessa análise e em informações inconsistentes sobre a vida social e os repertórios de Cavia e Galea, e sem qualquer conhecimento sobre o repertório da capivara, que as teorias de Lacher e Eisenberg foram propostas. Hoje, trinta anos depois adquiriu-se um vasto conhecimento sobre ecologia e comportamento, incluindo acústico, dessas espécies. Cavia não é promiscua como se imaginava e, apesar da proximidade com Galea, não se assemelha mais a ela do que ao mocó, em termos de estrutura social.

Essas teorias precisam ser revistas à luz do conhecimento adquirido e embasadas em uma descrição completa e detalhada do sistema de comunicação acústico do mocó, não só em cativeiro, mas em ambiente natural. Juntos, o conhecimento sobre Cavia, Galea, Kerodon e Hydrochoerus podem servir a estudos comparativos sobre a evolução da riqueza dos repertórios e de sinais específicos no ambiente de cada espécie, e fortalecer (ou enfraquecer) a existência de Hydrochaerinae (Figura 2). 
Adicionalmente, esse trabalho tem outra contribuição importante. Ao desenvolver estudo em uma região menos conhecida, como a caatinga promovemos e divulgamos conhecimento, valorizando essa região. Esse talvez seja o primeiro passo para a elaboração de políticas públicas de conservação desse bioma, exclusivamente brasileiro, fragilizado pela ação humana (por ex. a desertificação dos solos pelo desmatamento e queimadas, Castelletti et al. 2005). De seus $800.000 \mathrm{Km}^{2}$ de extensão, menos de $2 \%$ estão protegidos por Unidades de Conservação (Prado 2005). Pesquisas recentes, reunidas no Livro Ecologia e Conservação da Caatinga (Leal et al. 2005a), contradizem a visão tradicional e perigosa de que a Caatinga não é uma área de interesse para conservação pela pobreza paisagística e em biodiversidade. Por exemplo, Mares et al. (1985) descreveram os mamíferos da caatinga como um subconjunto das espécies do cerrado. Willig \& LacherJr (1991) descreveram a mastofauna do bioma como composto de apenas 80 espécies. 0 recente trabalho de Oliveira et al. (2005) corrigiu esse número para 143 espécies (no cerrado, seriam 159), 19 delas endêmicas ( $K$. rupestris e Wiedomys pyrrhorhinos) ou que apresentam grande parte de seu território na área da caatinga (espécies de gambá, sauá (Callicebus cupres), cutia (Dasyprocta $s p$ ), o cavíneo G. spixii, equimídeos e outros pequenos roedores).

Esse cenário nos leva a mais uma possibilidade de contribuição do trabalho e de outros que surjam a partir dele. 0 endemismo do mocó o coloca como um ponto-chave na discussão da origem evolutiva da caatinga. Seria a espécie remanescente de linhagens evolutivas autóctones, favorecendo a hipótese da maior antiguidade da Caatinga (Teoria dos Refúgios) ou teriam invadido a região em um momento posterior, como propõe a hipótese alternativa de Mares e colaboradores? (Mares et al. 1985; Oliveira et al. 2005) Estudos filogenéticos com base em caracteres comportamentais, como por exemplo, as vocalizações que compõe o repertório aqui descrito da espécie, poderiam fomentar essa discussão. 


\section{Objetivos}

O objetivo do trabalho foi descrever o repertório acústico do mocó, através de análise sonográfica dos sinais registrados em cativeiro e em ambiente natural. Essa descrição foi feita com a preocupação de produzir dados comparáveis aos já descritos repertórios de outros caviomorfos, criando um panorama filogenético para comparação e discussão sobre a evolução desse sistema de comunicação. 


\section{2- MATERIAIS E MÉTODOS}

\section{1 Área de estudo}

A pesquisa foi realizada no domínio morfoclimático da Caatinga, na região Nordeste do Brasil. A Caatinga esta distribuída entre os estados do Ceará, Rio Grande do Norte, a maior parte dos estados da Paraíba e Pernambuco, e regiões dos estados do Piauí, Alagoas, Sergipe e Bahia (Figura 1; Prado 2005).

A Caatinga é caracterizada pelo clima semi-árido e pela vegetação xerófila. Pelo estudo de Barbosa e colaboradores, 82\% das espécies lenhosas são decíduas, isto é, perdem as folhas no período crítico de estiagem, o que reduz a perda de água por transpiração. Os outros 18\% são de espécies perenifólias, com sistema de raízes bem desenvolvido, que captam água em solos menos xéricos, próximos a rios, riachos ou rochas. Esse grau de deciduidade durante a estação seca cria micro-ambientes mais úmidos e mais secos, como notam os autores, favorecendo estratégias diferenciais tanto em espécies vegetais como animais. A oferta de frutos carnosos acontece na estação chuvosa; frutos secos estão disponíveis no resto do ano. As flores também constituem importante fonte de alimento nas estações secas, pela menor dependência do regime pluvial e por seguir ritmos de regulação endógena (Barbosa et al. 2005).

A temperatura na Caatinga é alta oscilando entre 18 e $40^{\circ} \mathrm{C}$ durante o ano (Prado 2005). Há uma estação longa de seca - 7 a 10 meses ao ano, sendo os mais secos de maio a novembro - e distribuição muito irregular, portanto, imprevisível, de chuvas (total pluvial entre 250 e 900 mm/ano; Barbosa et al. 2005). Os solos são rasos e pouco permeáveis, portanto, sem condições de armazenamento de água (Barbosa et al. 2005).

Nosso trabalho foi realizado em duas localidades. No sítio Francisco de Assis (FA), uma pequena propriedade rural do município de São Mamede 
(coordenadas $6^{\circ} 48^{\prime} 10^{\prime \prime}$ Sul e $37^{\circ} 06^{\prime} 50^{\prime \prime}$ Oeste), Paraíba, onde os animais foram capturados e gravados em vida livre. Nas dependências da Fazenda Tamanduá, uma Reserva Particular do Patrimônio Natural (R.P.P.N.), localizada a uma distância aproximada de $50 \mathrm{Km}$ do Sítio FA, os animais foram mantidos em cativeiro e a maior parte dos dados foi ali coletada. Também foi a Fazenda que serviu de estadia ao pesquisador.

A Fazenda Tamanduá está localizada no município de Santa Terezinha, na Rodovia BR 361 (coordenadas 7 1' 31,76" Sul e 37²3’ 31,80" Oeste) (Figuras 3). Possui uma área natural preservada de 900 hectares, 325 deles averbados como RPPN e, desde 2000, certificados como Criadouro de espécies da fauna brasileira para fins conservacionistas, junto ao Instituto do Meio Ambiente IBAMA. A vegetação é caracterizada em sua maior parte por espécies caducifólias espinhosas e com presença de cactáceas. Há a presença de herbáceas que se desenvolvem principalmente no período chuvoso do ano e composição arbustiva e arbórea em sua maior parte é de xerófilas (Telino-Junior et al. 2005).

As espécies de árvores mais comuns são a catingueira (Caesalpina pyramidalis), a caraibeira (Tabebuia colubrina) e o angico (Anadenanthrera macrocarpa) (Paraíba, 2005).

Dos registros que se tem da fauna local constam os predadores Leopardus pardalis (Jaguatirica), Leopardus tigrinus (gato-do-matopequeno), Leopardus wiedii (gato maracajá), Puma concolor (onça vermelha), Puma yagouaroundi, conhecido popularmente como gato-domato-cinza-e-vermelho, Cerdocyon thous (cachorro-do-mato ou raposa), Chryscocyon brachyurus (lobo-guará), Speothos venaticus (cachorro-vinagre), Pseudalopex vetulus (Raposa do campo), Polyborus plancus (caracará) (Campos 2008). Outras espécies animais observadas na Fazenda incluem os roedores punaré (Thrichomys apereoides) e o preá-de-dente-amarelo (Galea spixii), serpentes dos gêneros Boa e Bothrops e ainda uma riqueza da 
avifauna com 145 espécies descritas distribuídas em 41 famílias (TelinoJunior et a., 2005).

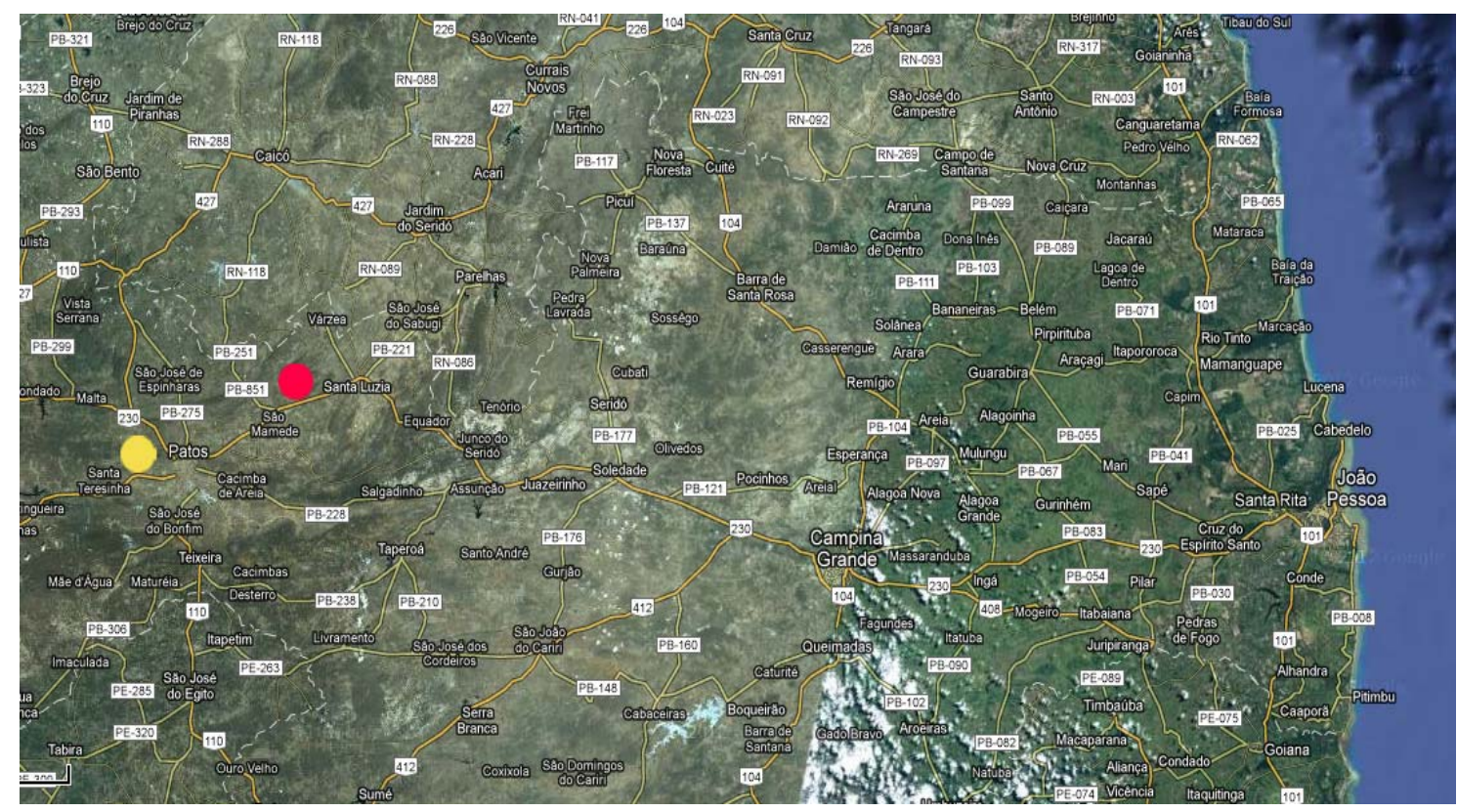

Figura 3: Localização da Fazenda Tamanduá (circulo amarelo), a principal área de estudo de mocós localizado entre os municípios de Pato e Santa Terezinha e localização do Sitio Francisco de Assis (círculo vermelho) local de captura do maior número de mocós localizado no município São Mamede, ambos pertencentes ao estado da Paraíba - Brasil.

\subsection{Captura e Identificação}

Os mocós que participaram deste estudo foram capturados, tanto no interior da Fazenda Tamanduá (FT), como no sítio Francisco de Assis. A primeira captura ocorreu no dia 13 de agosto de 2009, na FT. Como apenas um animal foi capturado (a fêmea Corine), preparamos uma segunda fase de captura em um local apontado como sendo de alta densidade de mocós, o sítio São Francisco distante $50 \mathrm{Km}$ da Fazenda Tamanduá. Lá foram capturados outros 12 animais ( 6 fêmeas e 6 machos). Para essa captura foram realizadas duas viagens a São Mamede. Em 21 de Agosto de 2009, fizemos o reconhecimento da área e escolhemos os locais para montar as armadilhas. Três semanas depois, em 19 de setembro de 2009, realizamos a captura que durou apenas um dia, já que novas viagens seriam difíceis, diante da falta de transporte tanto para os pesquisadores, quanto para os 
animais e a falta de estrutura para hospedagem. Esse único dia foi suficiente para a captura de um número satisfatório de animais para a realização desse trabalho.

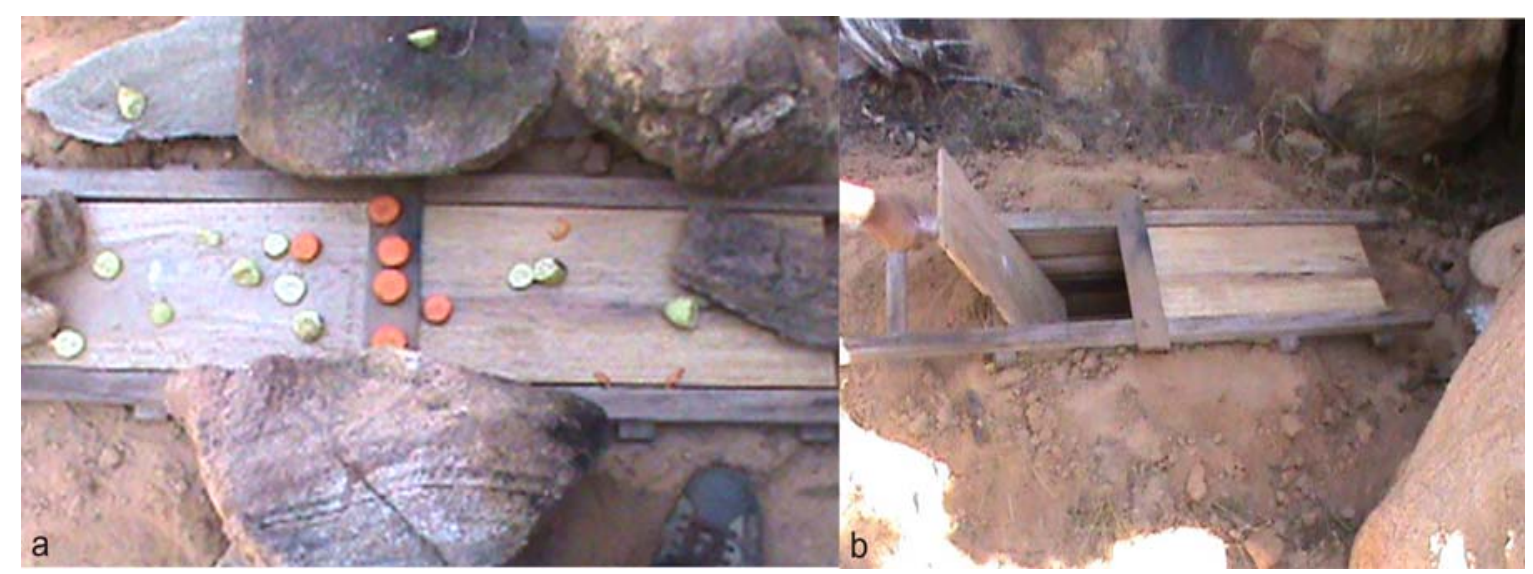

Figura 4: Armadilha do tipo pitfall usada para a captura de mocós (a) quando armada, com alimento sobre a tampa, que serviu de ceva, e (b) simulando o movimento da tampa quando a armadilha era ativada pelo peso de um animal.

Utilizamos armadilhas do tipo pitfall, localmente denominadas de "forjes", que confeccionamos em madeira, aproveitando o conhecimento dos habitantes locais que no passado caçavam mocós para alimentação. Havia uma tampa móvel que era acionada mecanicamente com o peso do animal quando este passava sobre ela. Para atrair os animais, usamos ramas de batata, abóbora e abacaxi. Uma vez dentro da armadilha, o animal não podia mais sair; a tampa travava-se se o animal a forçasse no sentido oposto ao da queda, isto é, para fora (Figura 4).

Foram usadas 3 armadilhas inspecionadas a cada 1 hora e quando atingimos o número de 12 animais demos por encerrada a captura. À medida que eram capturados, os animais iam sendo acomodados em 4 caixas de transporte previamente confeccionadas em madeira, três delas de 
dimensões 50x50x50 cm, com tampa de encaixe deslizante (Figura 5a), e uma maior $(61 \times 31 \times 31 \mathrm{~cm})$.

No mesmo dia 19, os animais foram acomodados em um veiculo alugado e levados à Fazenda Tamanduá em uma viagem que durou aproximadamente 40 minutos. Ainda nesse mesmo dia, os animais foram soltos, todos em um mesmo recinto de um cercado reformado e gentilmente cedido à pesquisa, pelo proprietário da Fazenda.

Dois dias após a soltura no recinto, cada animal recebeu um nome e foi identificado através de uma marca produzida com um descolorante de pelos atóxico (Figura 5b), seguindo procedimento previamente adotado com preás (Künzl \& Sachser 1999; Monticelli 2000). Os animais também foram medidos com uso de um paquímetro mecânico, com uma fita métrica com poder de medida de até 5 metros e pesados em uma balança Toledo 3400. As medidas tomadas foram o peso, o comprimento do corpo (do focinho à anca com a cabeça esticada), o comprimento da pata traseira, largura e altura dos testículos. Também fizemos anotações sobre o estado reprodutivo da fêmea - se lactante, grávida, ou a fase do cio, quando foi possível avaliar através do grau de abertura da vagina, seguindo procedimento adotado em nosso laboratório de Comunicação Animal - IPUSP com o auxílio da Profa. Elizabeth Spinelli de Oliveira - FFCLRP-USP; e ainda, se havia marcas pelo corpo e qual o aparente estado de saúde de animais dos dois sexos.

Durante todo o período em que foram mantidos no cercado (40 dias), os animais foram alimentados com itens naturalmente disponíveis na Fazenda, coletados pelo pesquisador. Eram ramas de tubérculos e frutos (banana, manga e abóbora) oferecidos a eles duas vezes ao dia - de manhã e ao final da tarde - e a oferta de água era ad libtum. Não choveu enquanto RNAJ esteve por lá, de Agosto a Outubro. Havia chovido alguns dias antes da sua chegada. 


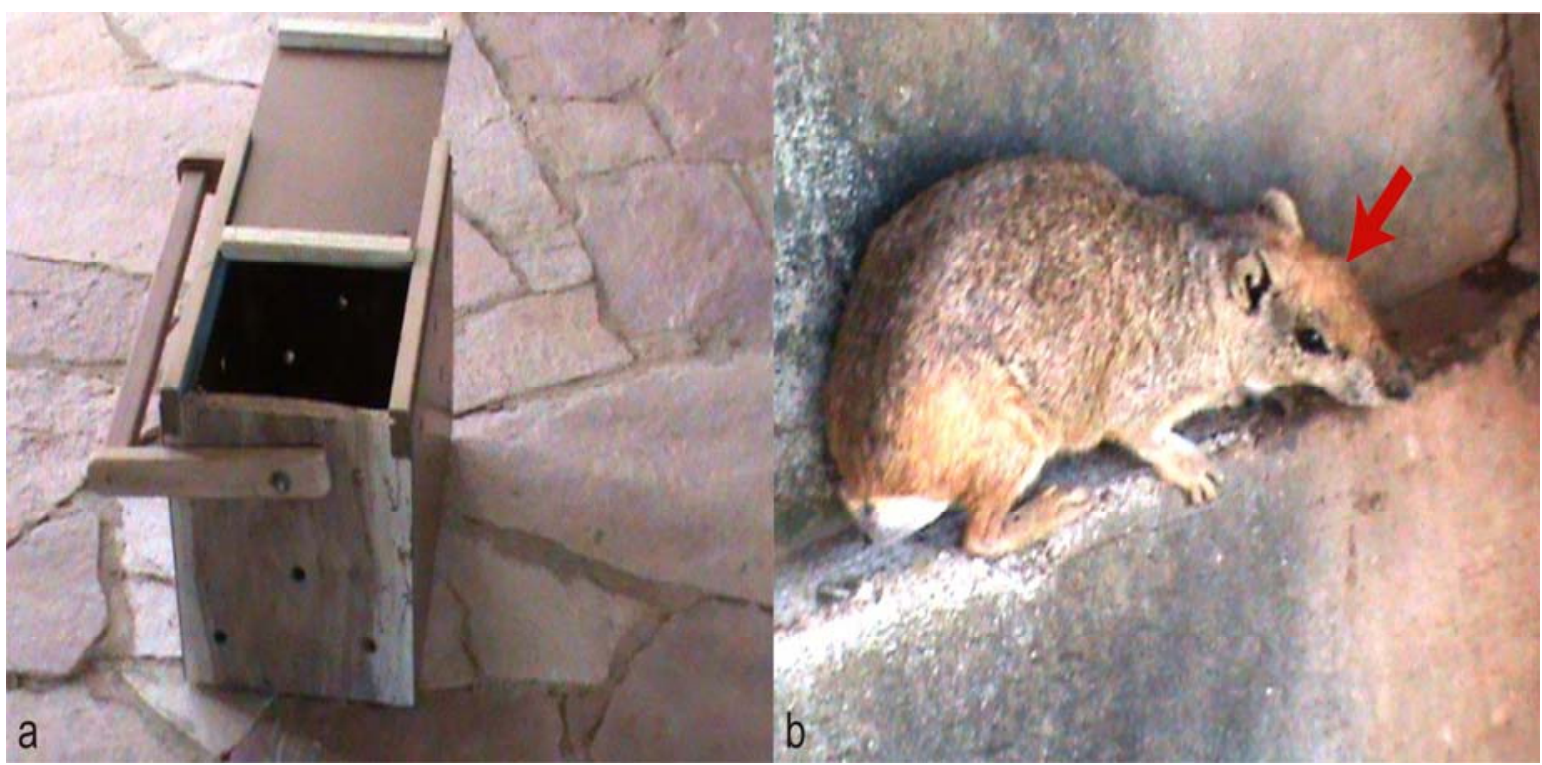

Figura 5: Caixa de transporte e marcação individual por descoloração. (a) Caixa utilizada para o transporte individual dos animais. (b) Um indivíduo macho identificado pela marca na cabeça (seta) produzida com esse método.

\subsection{Recinto e grupo de estudo}

0 recinto no qual os animais foram mantidos tinha dimensões $4,75 \mathrm{x}$ 2,60m. As paredes eram feitas de alvenaria e as divisórias internas eram revestidas com malha de ferro de fio $22 \mathrm{~mm}$. 0 teto era em declive $(1,90 \mathrm{~m}$ de altura em um dos lados e 2,30m do outro, Figura 6), coberto de telha de barro e palha de coqueiro. Também havia palha na lateral do recinto que sofria maior exposição ao sol à tarde. 0 piso era feito de terra batida.

Introduzimos um tronco de árvore que fincamos no chão, e um poleiro, respeitando os hábitos arborícolas da espécie (Figura 6c). Dentro do recinto disponibilizamos, ainda, uma caixa de madeira com uma pequena abertura que poderia servir de abrigo. 


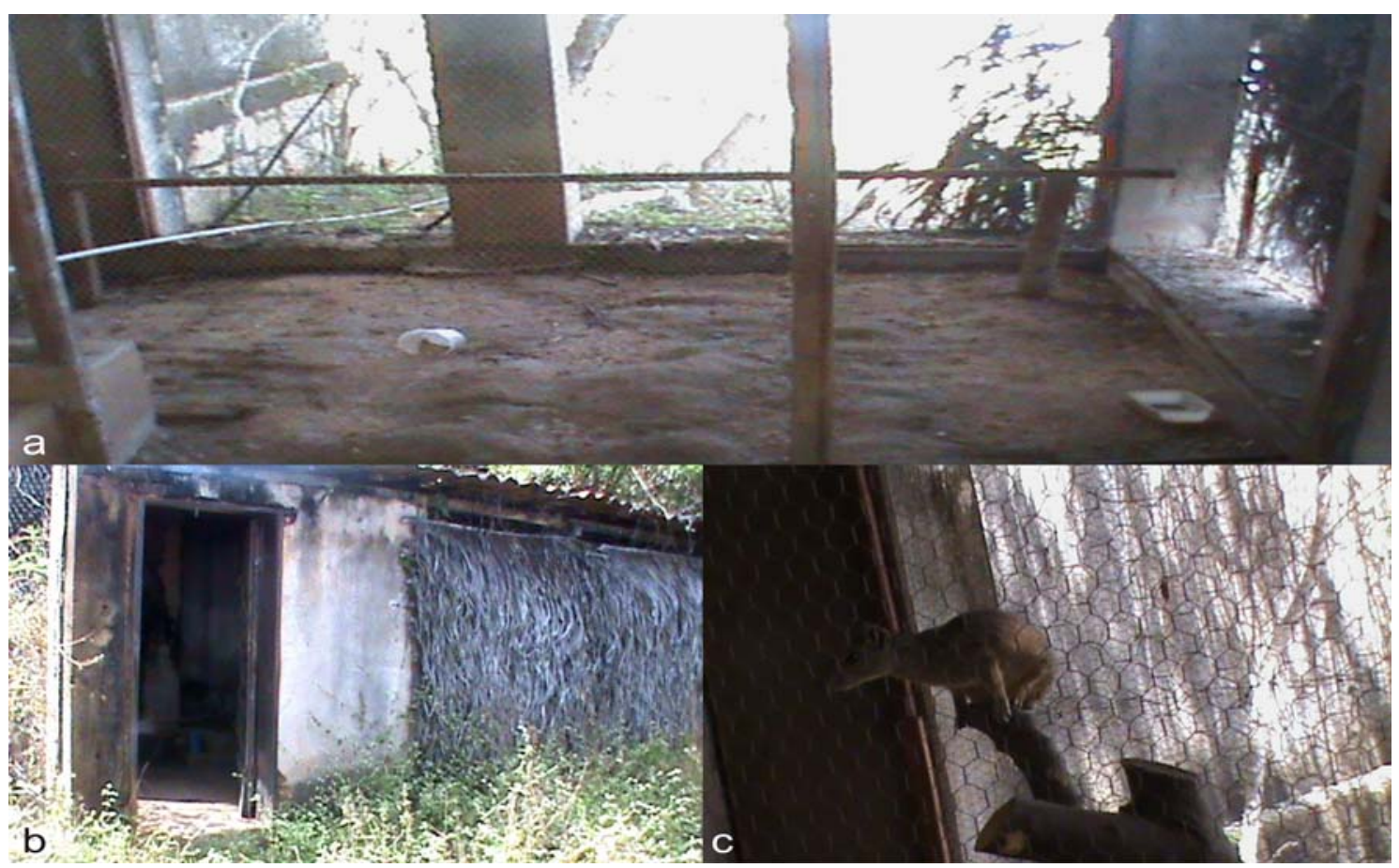

Figura 6: (a) Vista frontal do cativeiro que abrigou o grupo de mocós formado por 13 indivíduos capturados na Fazenda Tamanduá e no sitio Francisco de Assis; (b) Vista frontal da parte externa do cativeiro, sendo do lado direito a abertura (porta) que levava ao interior do recinto e no lado esquerdo da foto observa-se a forragem feita com palha de coqueiro, para o melhor conforto térmico dos animais e (c) Mocó utilizando o tronco que foi colocado dentro do recinto para preservar o hábito de escalar dos animais.

A reforma para a adequação do recinto pré-existente na fazenda durou aproximadamente 30 dias, período onde simultaneamente foram confeccionadas as armadilhas para a captura em campo e caixas de transporte. Toda a mão de obra e materiais utilizados na reforma e adequação do recinto que recebeu os animais nos foram oferecidos pelo Instituto Fazenda Tamanduá, que também ofereceu estadia e alimentação ao pesquisador na sede da fazenda, por 90 dias.

\subsection{Coleta dos dados acústicos e comportamentais}

A descrição do repertório de sinais acústicos de uma espécie exige uma coleta de dados exaustiva e variada, em termos de situações de registro. 
Assim, adaptamos o protocolo experimental de Monticelli (2005) e Berryman (1976) para a coleta de sons produzidos por mocós. Essas autoras simularam interações específicas entre animais através do pareamento deles, dois a dois, nas condições experimentais macho com macho (MM), fêmea com fêmea (FF) e macho com fêmea (MF), e de adultos com filhotes. 0 pareamento experimental de animais garante a obtenção de um número grande de chamados em condições relativamente controladas: restringe-se o número de animais interagindo por vez; cria-se a oportunidade de interações forçadas entre animais não familiares do mesmo sexo, que aumentam a chance de exibição de comportamentos de reconhecimento e agonisticos, e entre machos e fêmeas, o que costuma aumentar a probabilidade de interações de corte (Cohn et al. 2004); e pode-se criar condições de gravação com menor nível de ruído de fundo. Além disso, e para manter um ambiente de comparação com uma situação mais natural, essas autoras fizeram registros dos animais em grupos previamente estabelecidos (portanto de animais familiarizados e socialmente organizados), sem manipulação direta, e usaram ainda outras situações particulares.

Adotamos as três condições de pareamento (PA), MM, FF e MF, que conduzimos em um pequeno cômodo que nos foi cedido como sala de experimentação, próximo ao recinto. Adicionalmente, coletamos dados dos animais em grupo (GR), a partir dos 13 animais mantidos juntos em cativeiro, e de mocós em seu ambiente natural, em vida livre (VL). Os registros em VL aconteceram em dois momentos. 0 primeiro deles foi tomado do grupo habitante do Sítio Francisco de Assis, em São Mamede, no dia da captura. Não foi possível saber se se tratava de uma ou de várias colônias naquele único grande rochedo de aproximadamente $350 \mathrm{~m}^{2}$. 0 segundo momento se deu no local de soltura dos animais capturados em São Mamede, em uma área de aproximadamente $180 \mathrm{~m}^{2}$ da Fazenda Tamanduá, 
na qual havia um rochedo de aproximadamente $80 \mathrm{~m}$ de diâmetro (Tabela 1).

A coleta de dados nas 3 situações PA, GR e VL começou junto com o inicio das atividades de captura e se estendeu até o dia 06 de Outubro de 2009, quando, então, soltamos os animais nas dependências da Fazenda. Todos os procedimentos, desde a captura até a soltura de animais, foram aprovados pela Comissão de Ética em Pesquisa Animal (CEPA) do Instituto de Psicologia da Universidade de São Paulo (Certificado de aprovação identificado pelo número 004-2009).

Tabela 1: Distribuição em número de dias e tempo total investidos na coleta de emissões acústicas de mocós, em cada situação de registro: pareamento (PA), animais em grupo no cativeiro (GR) e animais em vida livre (VL). Os Valores entre parêntesis representam os valores parciais das condições MM, MF e FF de PA, e a Fazenda Tamanduá (FT) e o sitio São Francisco (SF) de VL.

\begin{tabular}{ccc}
\hline $\begin{array}{c}\text { Situação de } \\
\text { Coleta }\end{array}$ & $\begin{array}{c}\text { Distribuição } \\
\text { (em dias) }\end{array}$ & $\begin{array}{c}\text { Tempo Total } \\
\text { (em minutos) }\end{array}$ \\
PA & $\mathbf{6}$ & $\mathbf{9 0 0}$ \\
$(\mathrm{MM})$ & $(6)$ & $(300)$ \\
$(\mathrm{MF})$ & $(4)$ & $(300)$ \\
$(\mathrm{FF})$ & $(4)$ & $(300)$ \\
GR & $\mathbf{5}$ & $\mathbf{3 6 0}$ \\
VL & $\mathbf{5}$ & $\mathbf{4 5 0}$ \\
$(\mathrm{SF})$ & $(1)$ & $(40)$ \\
$(\mathrm{FT})$ & $(4)$ & $(410)$ \\
\hline
\end{tabular}

\section{PA: Pareamento experimental de animais}

Promovemos 10 sessões para cada condição (MM, FF e MF), cada uma com 10 minutos de duração, iniciados a partir da primeira movimentação de um dos animais na caixa-teste (Tabela 2). Essas sessões foram promovidas entre os dias 24 de Setembro e 6 de Outubro de 2009, em dias não consecutivos (isto é, para cada dia de sessões de pareamentos, fizemos um 
dia de descanso de gravações nessa condição). Eventualmente, nos vimos obrigados a repetir pares de sujeitos e reutilizar sujeitos em novos pareamentos devido à pequena amostra de animais que tínhamos. Nosso objetivo não era coletar dados sistemáticos para comparação estatística, mas sim aumentar a oportunidade de obtenção de diferentes sinais. Tomamos, contudo, o cuidado de não usar um mesmo animal duas vezes em um mesmo dia (Tabela 2), evitando um desconforto excessivo ao animal.

Tabela 2: Animais que participaram de cada sessão de pareamento, por condição experimental. A ordem dos pares e das condições MM, MF e FF na tabela refletem a ordem em que foram realizadas as sessões.

\begin{tabular}{cccc}
\hline Sessões & Macho x Macho & Macho x Fêmea & Fêmea x Fêmea \\
1 & Fabio x Manuel & Beto x Ariane & Joana x Helena \\
2 & Fabio x Beto & Pierre x Andrea & Andrea x Helena \\
3 & Fabio x Manuel & Fabio x Ariane & Ariane x Andrea \\
4 & Murilo x Kleber & Manuel x Clara & Ariane x Joana \\
5 & Pierre x Kleber & Fabio x Corina & Clara x Ariane \\
6 & Pierre x Manuel & Murilo x Corina & Corina x Andrea \\
7 & Pierre x Manuel & Kleber x Corina & Helena x Clara \\
8 & Fabio x Manuel & Murilo x Joana & Helena x Joana \\
9 & Beto x Murilo & Murilo x Vivi & Helena x Vivi \\
10 & Pierre x Kleber & Pierre x Clara & Vivi x Joana \\
\hline $\begin{array}{c}\text { Indivíduos } \\
\text { (n) }\end{array}$ & 6 & $6 \mathrm{M}, 6 \mathrm{~F}$ & 7 \\
\hline
\end{tabular}

A caixa de pareamentos possuía medidas de $80 \times 80 \times 80 \mathrm{~cm}$, desenvolvida com tampa móvel através da qual os animais eram introduzidos e retirados (Figura 7a). Essa tampa tinha uma moldura de madeira que prendia a malha de fio de ferro de $22 \mathrm{~mm}$. A parte inferior da caixa era de madeira e era forrada com tecido de algodão trocado por 3 vezes durante a fase experimental (Figura 7b). Esse tecido tinha a função de ajudar na visualização dos animais e reduzir o ruído produzido pelas patas sobre a madeira da caixa. A caixa tinha três laterais de madeira e a da frente 
era feita de vidro de $5 \mathrm{~mm}$ de espessura, para a visualização dos animais e as filmagens.

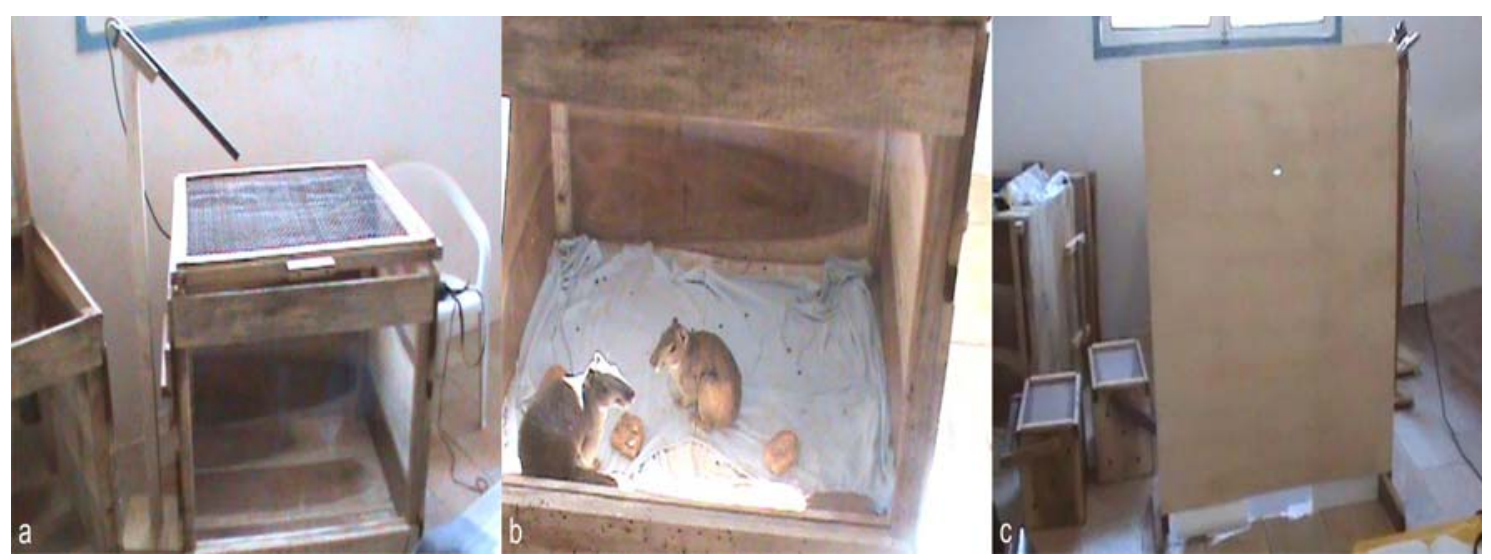

FIGURA 7: Condição experimental de pareamento de animais. (a) Vista frontal da caixa-teste utilizada nos pareamentos com o microfone posicionado no pedestal de madeira confeccionado para uso como suporte do microfone; (b) uma sessão, em andamento, de pareamento entre dois machos, com tecido revestindo o fundo da caixa e (c) anteparo de madeira por nós confeccionado e utilizado para que os animais não tivessem contato visual com o pesquisador, no canto inferior esquerdo, duas caixas de transporte individual de animais.

Para posicionar o microfone sobre a caixa, desenvolvemos um pedestal de madeira com uma base quadrada. Havia uma canaleta pela qual o microfone era introduzido, e uma borracha o fixava (Figura 7a).

Para diminuir efeitos da presença do experimentador sobre o comportamento dos animais nos pareamentos, adotamos o uso de um anteparo, também feito de madeira, com um pequeno orifício para a observação (Figura 7c).

\section{GR: Animais em grupo em cativeiro}

Chamaremos aqui de grupo de cativeiro aquele formado pelos 13 animais capturados em vida livre e mantidos no recinto da Fazenda. Após um período de 72 horas de habituação ao recinto e à nova composição 
social, iniciamos as gravações na condição GR, aproveitando os dias de descanso das gravações em PA.

Os registros em áudio e vídeo foram produzidos em horários e dias aleatoriamente determinados, a fim de se obter registros de diferentes aspectos do grupo, como, períodos de maior atividade em cativeiro, suas interações comportamentais, incluindo as acústicas, e a formação e manutenção de hierarquias ou outras formas de organização social. Obtivemos 360 minutos de registro simultâneo de áudio e vídeo (Tabela 1, p. $42)$.

O grupo (GR) formado para a coleta de dados nessa condição está ilustrada na Figura 8a. 0 microfone era posicionado a, aproximadamente, 50 cm do solo, a 1 ou 2 metros do centro do cercado. A filmadora ficou apoiada sobre um pedestal confeccionado em madeira e posicionado a 1,7 m. de altura do solo de maneira a capturar a imagem do maior e melhor ângulo possível do recinto. Contudo, foi impossível encontrar uma posição que cobrisse toda a área.

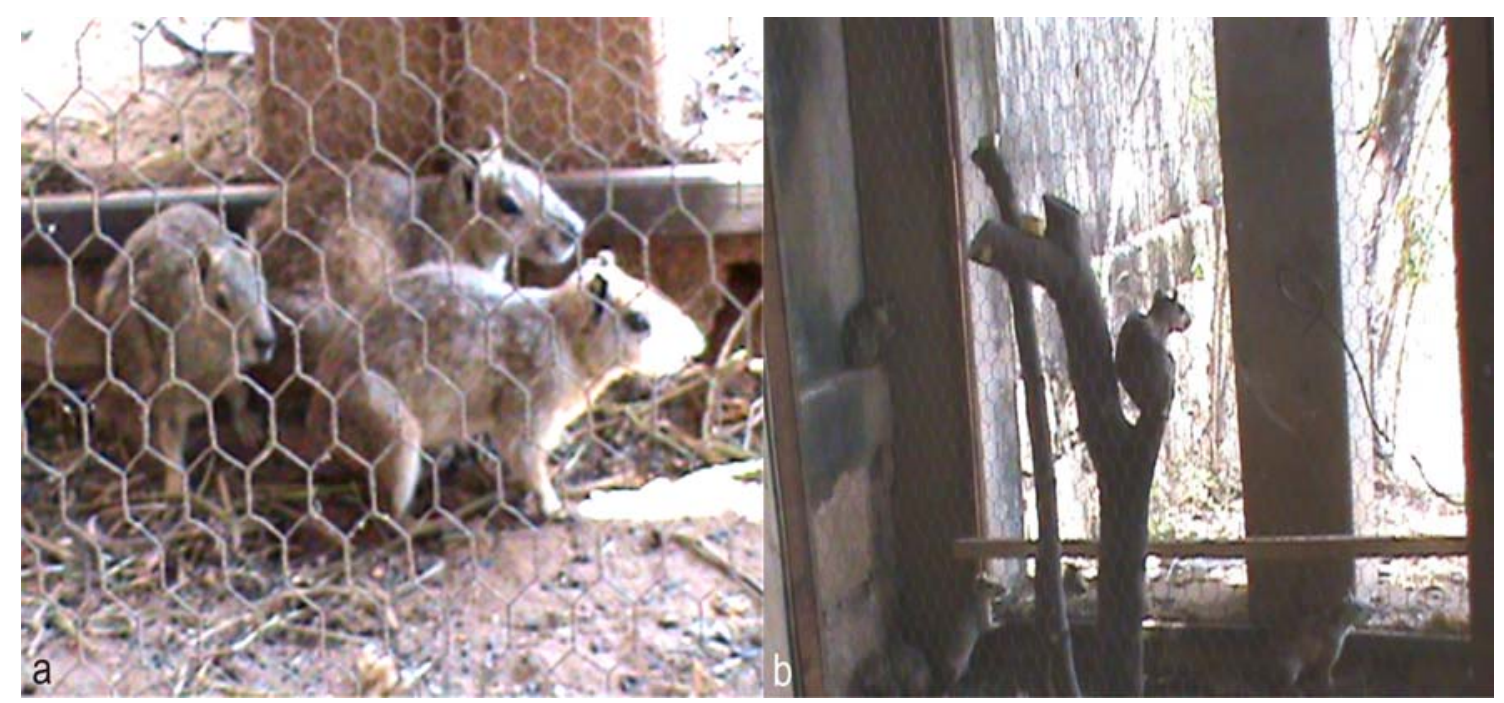

Figura 8: Animais em grupo no cativeiro: (a) três animais adultos no cercado dentro do recinto que nos foi cedido (Joana ao fundo, e outros dois indivíduos não identificados pela foto), e (b) visão mais ampla dos animais no cercado, um deles usando o tronco introduzido para esse fim. Todos os animais estão em postura de alerta, com os olhos dirigidos para um mesmo local, fora do recinto. 


\section{Vl: animais em vida livre}

As observações dos animais em VL foram conduzidas em diferentes dias e em dois locais, como dito anteriormente. Em SF, ocorreu em apenas um dia, no dia da captura (19/09/2009). Em FT aconteceram nos dias 8, 9, 10, 11 e 12 (no dia 9, fizemos várias observações distribuídas ao longo do dia). Como esses registros foram feitos após a soltura dos animais do cativeiro, foi possível identificar alguns emissores que ainda tinham visível a mancha de descoloração.

As observações foram conduzidas no período de maior atividade dos animais, ao entardecer, entre 16 e 17 horas, momento que favorecia a visualização dos animais fora dos rochedos, forrageando ou descansando sobre as rochas. Como nas outras condições de registro, utilizamos pedestais para posicionar a filmadora e o gravador em locais de maior circulação dos animais. A maior distância entre o microfone e um animal emissor foi de aproximadamente 3 metros. Como ilustrado na Figura 9, o microfone era posicionado a, aproximadamente, 1,70 metros de altura do solo, virado para cima, sob um ângulo aproximado de $110^{\circ}$ direcionado para onde os animais circulavam mais e ao que chamamos de "posto de observação". Correspondia a um local não necessariamente o mais alto do rochedo, mas que proporcionava uma boa visão do entorno e próximo a uma rota de fuga curta para o interior da rocha.

Cada sessão de gravação teve duração aproximada de 60 minutos, exceto no sitio do Sr. Francisco em São Mamede, onde o registro durou 40 minutos. Esse registro ocorreu no mesmo local e dia de captura da maior parte dos animais envolvidos na pesquisa. 0 pesquisador aproveitou a oportunidade de registro, já que o número de animais que circulava pelo rochedo foi consideravelmente grande e a experiência dos ajudantes que capturava os animais facilitou a oportunidade do registro desse grupo. 
Assim obtivemos aproximadamente 450 minutos de registros simultâneos em áudio e vídeo (Tabela 1). Durante as coletas em VL, o pesquisador manteve-se a uma distância de 2 a 6 metros dos animais, mantendo-se imóvel, o máximo possível, sem uso de anteparo ou camuflagem.

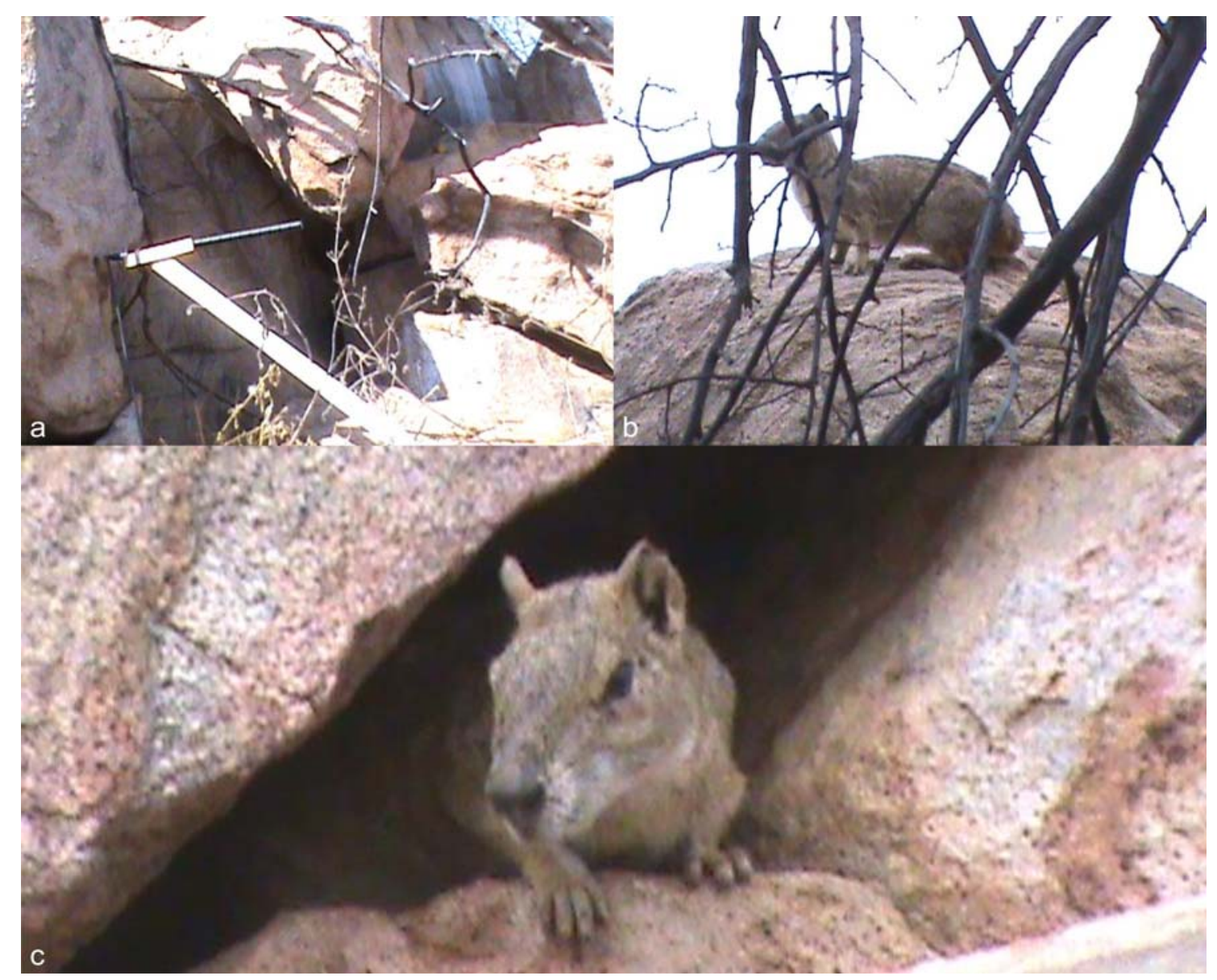

Figura 9: Condição de registro dos animais em vida livre. (a) Posição do microfone nos registros feitos no rochedo da Fazenda Tamanduá, apoiado no suporte de madeira; (b) um mocó no topo do rochedo, em postura de vigilância, no posto de observação, o local mais comum para a adoção de postura de vigilância e no qual os animais se revezavam, e (c) um mocó em uma fenda entre as rochas que lhes servia como abrigo na Fazenda Tamanduá, na área onde foram soltos ao término da viagem de coleta de dados.

\subsection{Soltura de animais}


A licença de pesquisa cedida pelo ICMBio ( $n^{\circ}$ 20038-1), além de nos permitir a captura e manutenção dos animais cativos, também nos permitiu soltá-los na FT. Esse procedimento visava iniciar um plano de aumento de população da espécie na fazenda com o conhecimento e consentimento do Sr. Pierre, proprietário da fazenda.

A Fazenda Tamanduá tem uma pequena e preocupante população de mocós, talvez pelo alto índice de predação por carnívoros de médio e grande porte restritos àquela área pela escassez de áreas de proteção no Estado (Campos, 2008). Esse fato que fez com que o mocó figurasse como membro da lista vermelha de animais ameaçados de extinção da IUCN até o ano de 2008.

Soltamos os 13 animais a uma distância de $3 \mathrm{~km}$ do local onde os mantivemos em cativeiro. Após a soltura fizemos registro de áudio e vídeo, como parte da coleta de dados utilizada nessa pesquisa, até o penúltimo dia de nossa estadia na fazenda.

\subsection{Análise dos dados}

Começamos analisando simultaneamente os registros visuais (vídeos) e acústicos (áudio) em busca de episódios (ocorrência da vocalização junto somada a observação do contexto de emissão) de produções sonoras de mocós. Sempre que identificávamos um episódio nos registros de vídeo, anotávamos (1) o momento e o tipo de emissão; (2) quem era o provável

emissor; (3) qual o comportamento que antecedia a emissão; (4) qual a reação do grupo ou do animal mais próximo e (5) qual a situação geral que gerou aquele episódio. Parte dos episódios registrados no cativeiro e em vida livre aconteceu com os animais fora do nosso campo de visão (escondidos entre as fendas das rochas ou fora do ângulo de filmagem do recinto) e não foi possível identificar o emissor ou o contexto.

Os sons coletados foram analisados usando os programas Avisoft SASLabPro 4.35 (Avisoft Bioacoustics, Berlim) e Raven 1.4 (Cornell Lab. of 
Ornithology, Ithaca). 0 programa Avisoft nos permitiu abrir arquivos grandes, com mais de 30 minutos de registros, impossíveis de serem trabalhados no Raven, e redigitalizar arquivos com taxas de amostragens menores, quando foi necessário (opção sampling frequency conversion). A Tabela 3 apresenta as configurações e as resoluções de tempo e frequência adotadas para a análise sonográfica de cada tipo de chamado. Utilizamos sempre a janela Hamming e DFT $1024 \mathrm{~Hz}$.

Tabela 3: Configuração adotada para a confecção dos sonogramas e resolução de frequência e tempo utilizadas na tomada de medida dos parâmetros acústicos no programa Raven 1.4, para cada sinal sonoro.

\begin{tabular}{lccccc} 
Sinal sonoro & $\begin{array}{c}\text { Frequência de } \\
\text { Amostragem } \\
(\mathrm{Hz})\end{array}$ & $\begin{array}{c}\text { Bandwidth } \\
(\mathrm{Hz})\end{array}$ & $\begin{array}{c}\text { Overlap } \\
(\%)\end{array}$ & $\begin{array}{c}\text { Resolução de } \\
\text { Frequência } \\
\text { (Hz) }\end{array}$ & $\begin{array}{c}\text { Resolução } \\
\text { de Tempo } \\
\text { (s) }\end{array}$ \\
$\begin{array}{lcccc}\text { Dhrrinho } \\
44.100\end{array}$ & 56 & 99 & 43.1 & 0,227 \\
Estalido & 4.000 & 56.1 & 99.3 & 5.86 & 0,167 \\
$\begin{array}{l}\text { Assobio de } \\
\text { alarme }\end{array}$ & 44.100 & 56 & 99 & 43.1 & 0,227 \\
Ganido & 44.100 & 56 & 99 & 43.1 & 0,227 \\
Grito & 44.100 & 56 & 99 & 43.1 & 0,227 \\
Arfar & 44.100 & 56 & 99 & 43.1 & 0,227 \\
Có de contato & 8.000 & 55.9 & 98.9 & 7.81 & 0,250 \\
Ronco & 44.100 & 66 & 99 & 43.1 & 0,204 \\
Silvo & 44.100 & 56 & 99 & 43.1 & 0,227 \\
$\begin{array}{l}\text { Bater-de- } \\
\text { dentes }\end{array}$ & 44.100 & 56 & 99 & 43.1 & 0,227 \\
\hline
\end{tabular}

Para a descrição dos sinais sonoros obtidos através da tomada dos parâmetros acústicos, seguimos o mesmo protocolo de Monticelli (2005), 
utilizando o programa de Raven 1.4. A partir dele, categorizamos os chamados de acordo com suas características visuais nos sonogramas e levando em conta a situação de emissão. Para todos os chamados medimos os seguintes parâmetros: duração das notas, número de frases por surto, frequência mínima, frequência máxima, número de harmônicos (para notas com estrutura tonal) e frequência dominante. Esses valores, registrados inicialmente em tabelas do próprio Raven, foram transportados para o programa Excel (Microsoft Office Versão 2007) para as análises descritivas das categorias acústicas identificadas. Para a descrição dos chamados usamos a seguinte terminologia (modificado a partir de Monticelli 2005):

Nota ou pulso/sílaba: menor unidade sonora sem intervalo interno. Alguns chamados são compostos de várias unidades emitidas seguidamente com intervalos regulares muito curtos, formando uma sílaba (conjunto de pulsos idênticos). É o caso do chamado de alerta de curta distância ou Drrr. 0 conjunto de pulsos forma a sílaba Drrr.

Frase: conjunto de unidades sonoras ou sílabas, de duração variável de acordo com o tipo de sinal (por exemplo, o ganido comumente dura 4 segundos, e o chorinho mais de $10 \mathrm{~s}$ ).

Surto: conjunto de frases emitidas em sequência a intervalos maiores do que os que separaram frases (atribuímos a esse intervalo o valor de 5 segundos). Os surtos podem ser bem longos, como aconteceu com o assobio de alarme que durou mais 10 minutos.

Intervalo: tempo que separa uma unidade sonora da outra, sejam elas, episódios, notas, pulsos ou frases.

Episódio: A ocorrência da vocalização, que pode surgir como uma nota isolada, uma frase ou em surtos de um ou mais tipos de sinais sonoros. Usamos esse termo para associar ocorrências acústicas e contextos de emissão. 
Intensidade: 0 programa Raven 1.4 fornece em tabela o valor do ponto com maior energia dentro da seleção escolhido no espectograma. A unidade de medida da intensidade é o decibel $(\mathrm{dB})$.

Frequência dominante: ponto único da nota, no eixo vertical de frequência, no qual a intensidade é máxima. 0 programa Raven fornece esse valor em tabela.

Harmônicos: Algumas notas possuem estruturas tonais, isto é, apresentam componentes de frequência múltiplos inteiros da fundamental. Medimos o número superior de harmônicos visíveis nas notas (por e. três, quando o segundo harmônico foi filtrado no gráfico, mas havia um acima dele).

\subsection{Equipamentos de registro}

Para o registro das vocalizações utilizamos um gravador portátil digital Marantz PMD660 661 (D\&M Holdings Inc, Mahwah, Nova Jersey; (frequência de amostragem $48 \mathrm{kHz}$, resposta de frequência: $16.000 \mathrm{~Hz} \pm-0.5$ $\mathrm{dB}$; faixa dinâmica $>80 \mathrm{~dB}$ ), um microfone hipercardióide direcional Sennheiser ME67 (Sennheiser Communications A/S, Solrod Strand, Dinamarca) alimentado por um módulo K6, e um fone de ouvido Sennheiser HD 265. As filmagens foram feitas com uma filmadora digital Sony DCR-SR 47 (Sony Eletronics Inc., São Diego, CA), que registra os dados em um cartão de memória. As análises sonográficas foram realizadas a partir de um computador portátil pessoal Acer Aspire 4720Z . 


\section{RESULTADOS}

\subsection{Dados morfométricos}

Apresentamos na Tabela 4 as medidas morfométricas tomadas dos animais capturados antes de serem incluídos no grupo estabelecido em cativeiro. Pela avaliação externa do estado dos animais, das mamas e da membrana vaginal, pode-se dizer que não foram capturadas fêmeas lactantes nem em estro, e que todos os animais estavam aparentemente livres de ectoparasitas, não estavam desnutridos e não possuíam ferimentos aparentes nem cicatrizes profundas. Durante o tempo em que permaneceram em cativeiro, as fêmeas não apresentaram sinais de estarem grávidas e não ocorreram nascimentos. Isso mostra que dentre as fêmeas capturadas, nenhuma estava grávida ou que, se estava, a gestação foi interrompida.

\subsection{Repertório acústico: tipos de sinais}

Analisamos 1.110 minutos de registros simultâneos de áudio e vídeo distribuídos nas três situações de coleta de dados. Nessa análise, reconhecemos 11 tipos de sinais acústicos, dez aparentemente vocais, e um não vocal, produzido pelo entrechoque dos dentes. A proporção de sinais obtidos em cada situação de registro está indicado na Tabela 5. A situação que mais gerou sinais distintos foi PA; a menos variada em sinais foi VL. Dois sinais parecem ser emitidos com mais frequência pelos mocós e apareceram nas três situações PA, GR e VL. Foram o Assobio de alarme, emitido, em geral, por animais em postura de alerta (ou por animais que foram agredidos, na presença do agressor), e o Drrr que contextualizamos como chamado de exploração. As outras emissões se dividiram entre as situações 
de coleta. Por exemplo, o Ganido foi emitido nas condições PA e GR, mas não em VL; o Silvo só aconteceu em VL e o bater-de-dentes ocorreu em PA e VL (Tabela 6).

Tabela 4: Medidas morfometricas dos animais capturados, por sexo $(\mathrm{n}=7$ fêmea, 6 machos). As medidas estão representadas pelos seus valores médios, desvios-padrão (entre parêntesis) e valores mínimos e máximos, o peso em gramas e as outras medidas em milímetros.

\begin{tabular}{lccc}
\multicolumn{1}{c}{ Medidas } & Sexo & Média \pm dp & Mín-Máx \\
Comprimento da cabeça & Macho & $80,3 \pm 3,3$ & $76-85$ \\
& Fêmea & $81,6 \pm 7,3$ & $73-90$ \\
Largura da cabeça & Macho & $35,8 \pm 1,0$ & $34-37$ \\
& Fêmea & $34,4 \pm 2,3$ & $31-38$ \\
Comprimento do pé & Macho & $61,8 \pm 5,2$ & $57-71$ \\
Altura dos testículos & Fêmea & $58,7 \pm 3,6$ & $53-64$ \\
Largura dos testículos & Macho & $36,2 \pm 6,2$ & $28-46$ \\
Comprimento do corpo & Macho & $26,2 \pm 8,5$ & $14-36$ \\
& Fêmea & $323,0 \pm 19,2$ & $290-340$ \\
Peso do corpo & Macho & $680,0 \pm 128,1$ & $540-905$ \\
& Fêmea & $687,1 \pm 149,3$ & $490-845$ \\
\hline
\end{tabular}


Tabela 5: Repertório total e proporção de sinais sonoros diferentes obtidos em cada situação de coleta: nos Pareamentos (PA: MM, MF e FF), animais em grupo em cativeiro (GR) e animais em vida livre (VL) nas duas localidades, sitio São Francisco e Fazenda Tamanduá (SF e FT).

\begin{tabular}{ccc}
\hline \multicolumn{2}{c}{ Situação de Coleta } & Número de tipos \\
\multirow{3}{*}{ PA } & (MM) & $(8)$ \\
& (MF) & $(4)$ \\
& (FF) & $(6)$ \\
& & 6 \\
\hline GR & $(\mathrm{SF})$ & $(4)$ \\
VL & (FT) & $(4)$ \\
& & 4 \\
\hline Repertório & & 11 \\
\hline
\end{tabular}

Identificamos três categorias comportamentais abrangentes nas quais os sinais foram emitidos, sendo elas: (1) Exploração/Forrageamento, aqui incluímos itens da categoria de manutenção (Maintenance Behavior) descritas por Lacher (1981), como: investigação olfativa ou visual do ambiente social e físico, forrageamento e locomoção, escalar e atenção (2) Alerta: inclui comportamentos de atenção ou autodefesa; os animais tomam a postura de observação, semelhante à postura de alerta de Cavia, (Messias 1995) e/ou fogem para abrigos ou afastam-se de estímulos ambientais repentinos, sons e aproximação humana ou de outros animais; (3) Interação Agonística: inclui os comportamentos de ataque, (Attack lunge), Caçada (Chase) e ameaça (Stand threats) descritos por Lacher (1981) e a Encarada de Monticelli (2005) exibidos em situações de enfrentamento, exibição visual ou briga. 
Tabela 6: Contexto geral de emissão dos sinais. Para cada categoria ampla de comportamento, a ocorrência dos sinais está indicada por $\mathrm{x}$, para as situações de coleta em grupo (GR) e em vida livre (VL). Para os pareamentos, que envolveram coletas sistemáticas de dados, apresentamos o número de sessões (entre parêntesis, o número de surtos) em que as emissões foram registradas.

\begin{tabular}{|c|c|c|c|c|}
\hline $\begin{array}{c}\text { Categoria de } \\
\text { Comportamento }\end{array}$ & Sinal Acústico & PA & GR & VL \\
\hline \multirow{3}{*}{ Alerta } & Assobio de alarme & & $\mathrm{x}$ & $\mathrm{X}$ \\
\hline & Drrr & & $\mathrm{x}$ & $\mathrm{X}$ \\
\hline & Silvo & & & $\mathrm{X}$ \\
\hline \multirow{4}{*}{ Exploração } & Chorinho & $6(42)$ & $\mathrm{x}$ & \\
\hline & Drrr & $6(21)$ & $\mathrm{x}$ & $\mathrm{X}$ \\
\hline & Có & & $\mathrm{x}$ & \\
\hline & Estalido & $3(3)$ & & \\
\hline \multirow{6}{*}{$\begin{array}{l}\text { Interação } \\
\text { Agonística }\end{array}$} & Assobio de alarme & $2(3)$ & & \\
\hline & Ganido & $3(3)$ & $\mathrm{x}$ & \\
\hline & Grito & $2(2)$ & & \\
\hline & Ronco & & $\mathrm{x}$ & \\
\hline & Arfar & $3(12)$ & & \\
\hline & Bater-de-dentes & $8(8)$ & & $\mathrm{X}$ \\
\hline
\end{tabular}

Dos 11 sinais identificados, categorizamos 4 como de exploração, 3 como alerta e 6 como agonísticos (Tabela 6). A maior proporção de 
chamados agonísticos foi registrada em PA. De forma curiosa, até o Assobio de alarme registrado nessa situação, aconteceu em um contexto agonístico: foi emitido por animal após sofrer ataque do agressor. Os chamados agonísticos em GR ocorreram em situação levemente agressiva, quando um animal expulsava outro do local de forrageamento ou de descanso, algumas vezes com perseguição. Fora essas situações, as outras vocalizações emitidas em GR foram os chamados de contato (Exploração social), emitidos quando os animais se aproximavam, e bastante frequentes nos primeiros dias, quando o grupo estava se organizando hierarquicamente; e chamados de alerta, quando surgiam estímulos novos, repentinos.

É importante notar que a vocalização que denominamos Drrr aconteceu tanto em Alerta como Exploração. Em alerta, aconteceu em GR sempre que o ambiente era alterado, fosse quando o pesquisador entrasse no recinto, ou quando um animal era inserido no ambiente (vindo de uma captura ou reinserido após uma sessão de pareamento). Em VL, o Drrr em geral surgiu com os animais se deslocando pelo ambiente, não ficando claro para o pesquisador nenhuma alteração que indicasse o contexto de alerta. Nos pareamentos aconteceu apenas em Exploração, no entanto o contexto de Alerta não pode ser destacado aqui, visto que o ambiente cheio de estímulos estranhos aos animais sugere esse contexto.

\subsection{Descrição e caracterização estrutural dos sinais sonoros}

A seguir descrevemos estruturalmente e de forma contextualizada os sinais que não deixaram duvidas quanto a sequência de acontecimentos que precederam e sucederam a sua emissão. As 11 emissões aqui identificadas como parte do repertório acústico da espécie $K$. rupestris, nós as separamos em três categorias comportamentais, 1) exploração/ forrageamento, 2) alerta e 3) interações agonísticas às quais foram associados as vocalizações. A tabela 7 (abaixo) resume os valores médios, desvios-padrão, mínimos e 
máximos dos parâmetros usados para a caracterização quantitativa dos sinais. Informações adicionais e particularidades estruturais e de contexto, estão descritas ao longo do texto.

Tabela 7: A estrutura física dos 11 sinais que compõem o repertorio da espécie $K$. rupestris. As medidas estão representadas pela média (desvio-padrão) e mínimomáximo. Apresenta-se também o número amostral $(\mathrm{N})$ de notas (frases, no caso do Drrr) usadas para essa descrição. A duração está expressa em segundos e as medidas de frequência em $\mathrm{kHz}$.

\begin{tabular}{lcccccc} 
& & $\begin{array}{c}\text { Duração das } \\
\text { notas }\end{array}$ & $\begin{array}{c}\text { Frequência } \\
\text { Mínima }\end{array}$ & $\begin{array}{c}\text { Frequência } \\
\text { Máxima }\end{array}$ & $\begin{array}{c}\text { Frequência } \\
\text { Dominante }\end{array}$ & $\begin{array}{c}\text { Número de } \\
\text { Harmônicos }\end{array}$ \\
1. Chorinho & N22 & $0,13(0,09)$ & $1,0(0,3)$ & $4,4(2,6)$ & $1,6(0,7)$ & $2,2(1,1)$ \\
& & $0,01-0,5$ & $0,3-2,7$ & $0,8-1,7$ & $0,4-6,2$ & $1-9$ \\
2. Drrr & 68 & $0,2(0,1)$ & $0,2(0,09)$ & $0,8(0,4)$ & $0,4(0,2)$ & \\
& & $0,08-0,6$ & $0,1-0,5$ & $0,3-2,2$ & $0,2-0,9$ & \\
3. Estalido & 23 & $0,02(0,01)$ & $3(2,3)$ & $12,7(3,6)$ & $5,5(4,0)$ & \\
& & $0,01-0,04$ & $0,6-6,7$ & $3,5-18,7$ & $0,6-13,1$ & \\
4. Assobio de & 224 & $0,06(0,1)$ & $1(0,2)$ & $5(1,8)$ & $2,3(0,1)$ & $2,3(1,8)$ \\
alarme & & $0,02-2$ & $0,04-2$ & $1,3-13,2$ & $0,6-3,3$ & $1-11$ \\
5. Ganido & 29 & $0,13(0,18)$ & $0,9(0,6)$ & $3,5(3)$ & $1,3(0,8)$ & $2,3(1,6)$ \\
& & $0,02-0,7$ & $0,005-2,3$ & $0,7-15,5$ & $0,1-2,9$ & $1-8$ \\
6. Grito & 5 & $0,25(0,29)$ & $0,5(0,1)$ & $3(1,8)$ & $0,8(0,2)$ & $2,6(0,5)$ \\
& & $0,08-0,6$ & $0,4-0,8$ & $0,9-5,5$ & $0,6-1,2$ & $2-3$ \\
7. Arfar & \multirow{2}{*}{89} & $0,10(0,05)$ & $1,7(1,3)$ & $11(3,2)$ & $3,4(2,5)$ & \\
& & $0,01-0,2$ & $0,1-1$ & $5-20,7$ & $0,1-13$ & \\
8. Có & \multirow{2}{*}{31} & $0,08(0,1)$ & $0,5(0,1)$ & $0,8(0,1)$ & $0,7(0,1)$ & \\
& & $0,03-0,5$ & $0,2-0,7$ & $0,6-1,5$ & $0,5-0,9$ & \\
9. Ronco & \multirow{2}{*}{50} & $0,12(0,04)$ & $0,3(0,04)$ & $6,5(3,7)$ & $1,6(1,4)$ & \\
& & $0,04-0,2$ & $0,1-2,5$ & $0,6-18,2$ & $0,2-5,2$ & \\
10. Silvo & \multirow{2}{*}{6} & $1,3(0,2)$ & $6,3(0,9)$ & $7,5(0,4)$ & $7(0,1)$ & $1(0)$ \\
& & $0,9-1,5$ & $6,2-6,5$ & $7-8,1$ & $6,6-7$ & \\
11. Bater-de- & \multirow{2}{*}{127} & $0,03(0,01)$ & $0,9(0,6)$ & $2,5(5,7)$ & $1,2(2,3)$ & \\
dentes & & $0,01-0,05$ & $0,03-3,1$ & $1,2-2,2$ & $0,04-11,2$ & \\
\hline
\end{tabular}

\subsubsection{Chorinho}

\section{Churr (Lacher, 1981)}

Essa vocalização é muito discreta ao ouvido humano e emitida com frequência por animais durante exploração da caixa em PA ou do recinto em GR. Trata-se de notas isoladas ou frases que podem variar em número de 
notas e estrutura, que têm em comum a combinação de transições entre modulações ascendentes, descendentes e fases de sustentação.

Em média, as notas duram 0,09 s, ocupam a faixa estreita de frequência entre 0,5 e $4 \mathrm{kHz}$, têm frequência dominante em $1,4 \mathrm{kHz}$ e 2 harmônicos. Em grupo o Chorinho apresentou surtos mais longos (superior a 20s) e maior combinação de notas em relação aos surtos dos pareamentos

A Figura 10 apresenta uma frase de 11 notas todas apresentando estruturas tonais mas com modulação de frequência distintas entre si. A primeira nota apresentando modulação de frequência inicial em ondulações levemente ascendente, uma segunda fase levemente descendente, entrando numa fase de sustentação apresentando 2 harmônicos ocupando faixa de frequência entre $1 \mathrm{kHz}$ e $3 \mathrm{kHz}$. A segunda nota possui fase inicial breve sem modulação de frequência, seguida de leve ascendência para descender acentuadamente, apresentando 4 harmônicos. A terceira e quinta notas são muito breves sendo a terceira com modulação de frequência em formato de "M" apresentando 2 harmônicos e a quinta sem modulação de frequência. A quarta nota também em formato de $M$, mas com duração e amplitudes maiores em relação à nota 3 e apresentando 3 harmônicos. A sexta, sétima e oitava notas são idênticas apresentando fase inicial ascendente e uma segunda fase apresentando breve sustentação e finalizando com uma fase descendente acentuada apresentando de 2 a 3 harmônicos. A décima nota com modulação de frequência em forma de parábola, ascendendo e descendendo com 3 harmônicos. 


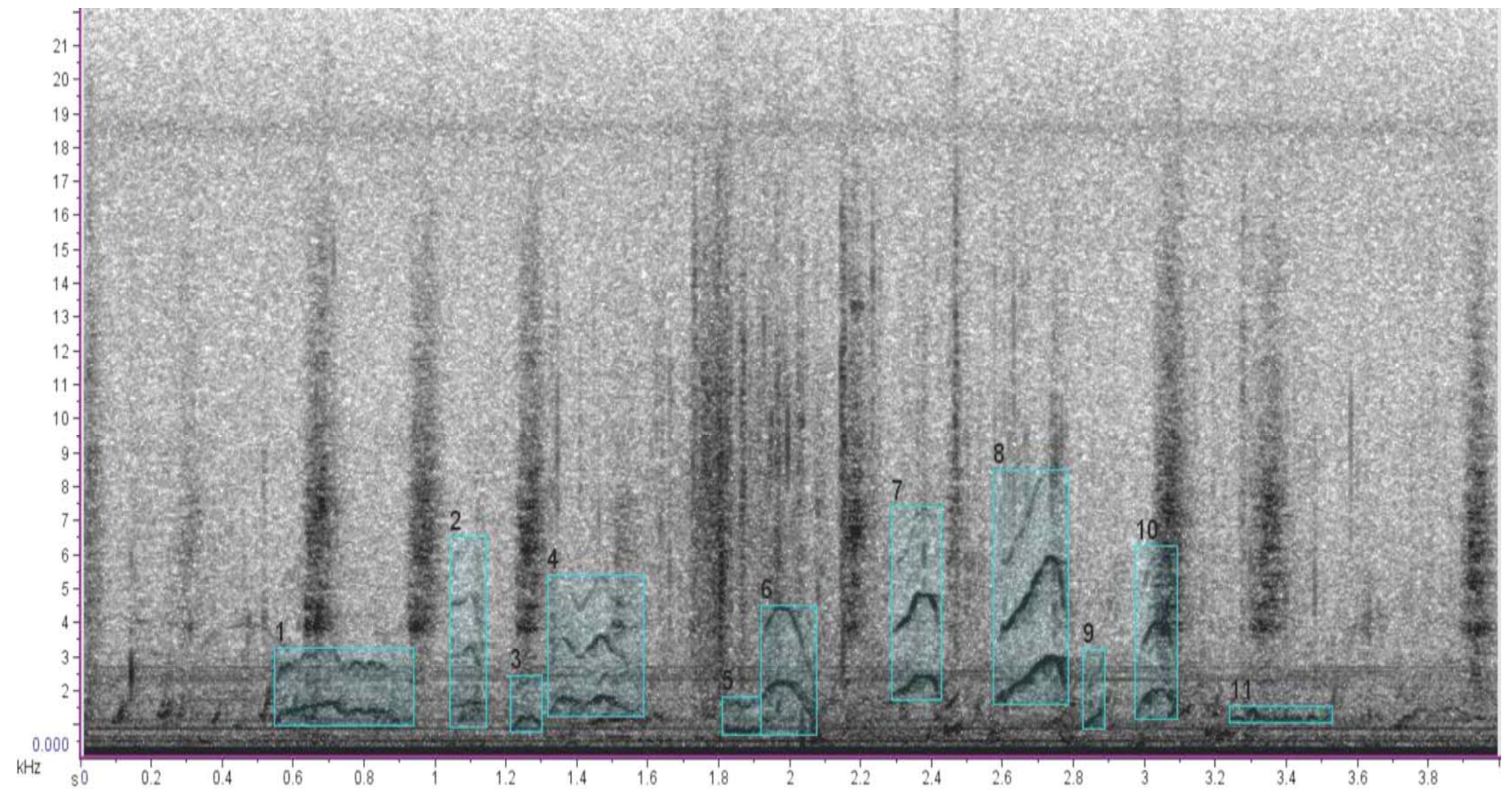

Figura 10: Sonograma de uma frase de Chorinho de menos de $4 \mathrm{~s}$, composta por 11 notas (retângulos verdes numerados) de contornos (modulação de frequência) variados, e ocupando a faixa de 1 a $8 \mathrm{kHz}$. É possível que haja dois animais vocalizando ao mesmo tempo, como sugere a sobreposição entre as notas 3 e 4 e 5 e 6. 


\subsubsection{Drrr}

\section{Drrr (Berryman, 1976; Monticelli, 2005)}

Essa vocalização é também de difícil percepção ao ouvido humano pela pouca intensidade e por ocupar uma faixa tão baixa de frequência. Para que pudéssemos obter uma melhor visualização e analisá-la tivemos de ajustar a frequência de amostragem (sampling frequency) para $8 \mathrm{kHz}$. Aqui utilizamos a mesma onomatopéia adotada por Berrymam, (1976) para descrever o sinal de alarme de curta distância pertencente à Cavia, denominação que foi seguida por Monticelli (2000). Fizemos isso porque, ao sonograma, esse sinal produzido pelo mocó é muito semelhante ao Drrr de Cavia.

O Drrr foi produzido durante a exploração e reconhecimento do novo ambiente, enquanto os animais circulavam pela caixa, nas três condições de PA: MM, MF e FF. Não foi possível identificar os emissores nessa situação, porque o sinal é produzido com a boca fechada. No contexto de alerta esse sinal ocorreu com os animais em Grupo e ocorreu quando alguma alteração no ambiente foi promovida, seja com a entrada do pesquisar no recinto ou a inserção de um animal (vindo de captura ou da sessão de pareamento).

Trata-se de repetição de notas extremamente breves (pulsos), separadas por intervalos também muito breves. 0 conjunto desses pulsos, que é o que constitui o chamado, chamamos frase. As frases de Drrr têm, em média, 3 pulsos com duração de 0,02s., frequência mínima de $0,2 \mathrm{kHz}$ e máxima de $0,8 \mathrm{kHz}$. A estrutura não é harmônica, embora haja uma faixa de maior energia que coincide com a frequência mínima. A Figura 11 mostra 3 sonogramas de Drrr. 


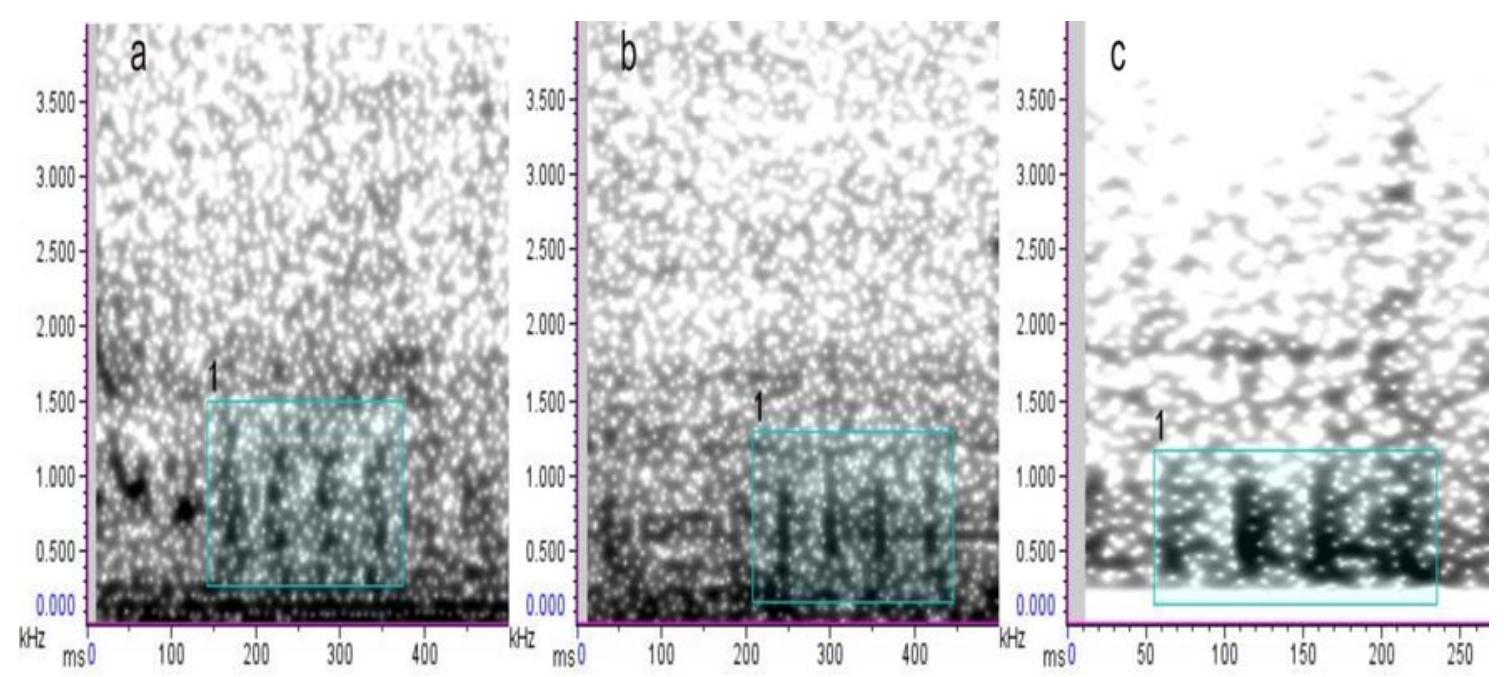

Figura 11: Três Sonogramas de frases de Drrr. Os retângulos verdes delimitam aproximadamente as frases: (a) frase com 4 notas na faixa de frequência de 0,3 a $1,5 \mathrm{kHz}$; (b) 4 notas na faixa de frequência de 0,2 e 1,3kHz; (c) 4 notas na faixa de frequência de 0,2 e 1,2kHz, gerada após ajuste da frequência de amostragem para $8 \mathrm{kHz}$ ( $\mathrm{a}$ e $\mathrm{b}$ foram feitas usando-se $44 \mathrm{kHz}$ de frequência de amostragem).

\subsubsection{Estalido}

Esse sinal aconteceu em todas as condições de PA (MM, MF e FF). 0 Estalido (Figura 12) é um pulso de ampla faixa de frequência que dura, em média, $0,02 \mathrm{~s}$ e é repetido a intervalos irregulares, apresentando sob a forma de surtos relativamente longos, de mais de 4 segundos.

Há grande variação no inicio e término da faixa de frequência ocupada por cada pulso. Há aqueles que têm frequência mínima em $1 \mathrm{kHz}$, enquanto outros iniciam-se por volta de $11 \mathrm{kHz}$ (Figura 12, pulso 9). Em média, a frequência mínima é de $3 \mathrm{kHz}$, a máxima de $12,7 \mathrm{kHz}$ e a dominante está em $5,5 \mathrm{kHz}$. 


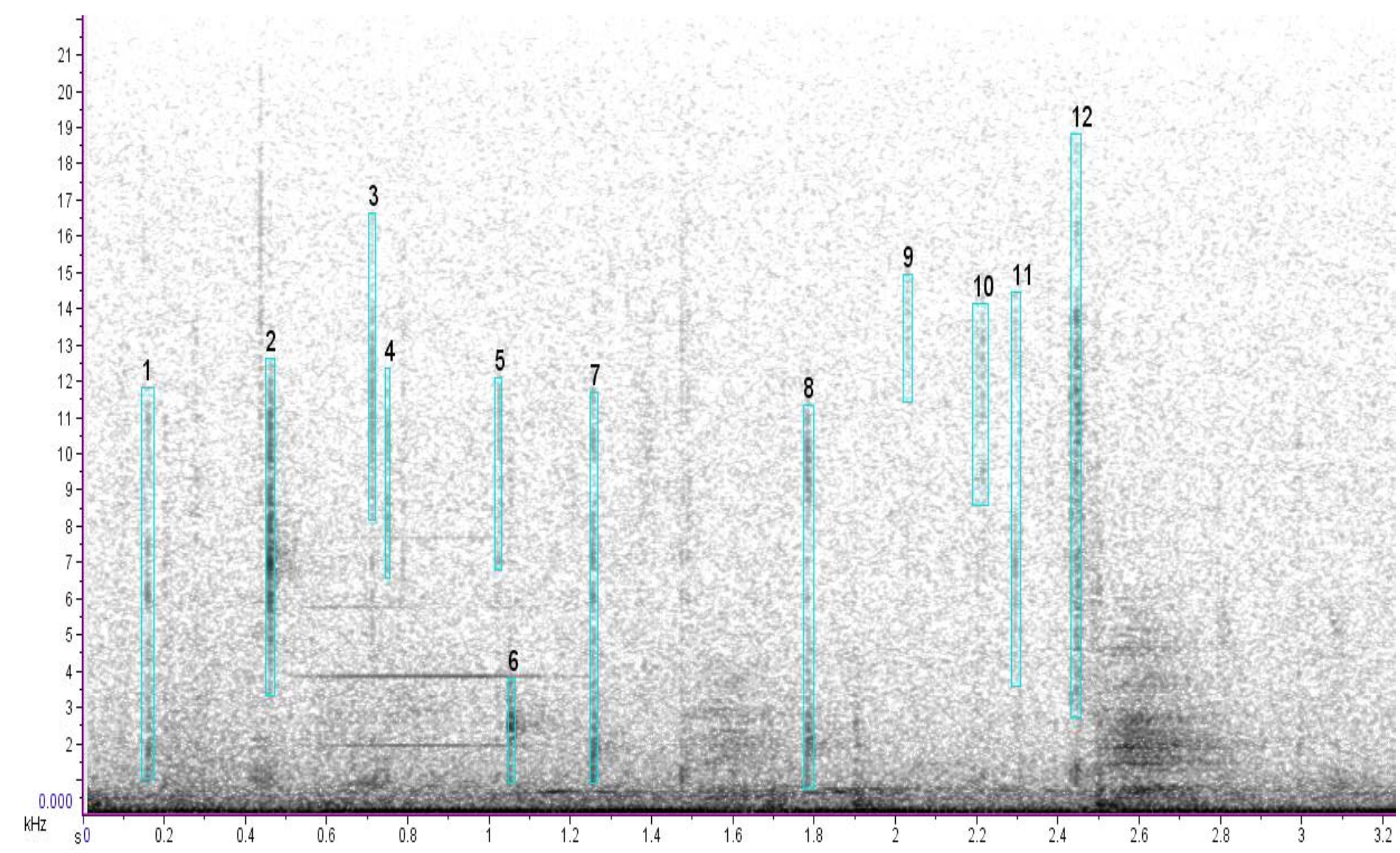

Figura 12: Sonograma de uma frase de Estalido de 2,2 segundos de duração, 12 notas de faixa de frequência variável, entre 0,5 e $19 \mathrm{kHz}$. 


\subsubsection{Assobio de alarme ou latido}

\section{Alarm whistle (Lacher, 1981)}

Esse chamado é de fácil identificação ao ouvido humano pela sua alta intensidade e por lembrar um latido agudo de um cão. Foi produzido, mais comumente, em situação de alerta. Parecia ser eliciado por estímulos que representavam perigo potencial (como a presença de humanos, cães, ou aves de rapina ou acústicas da presença deles). Tanto em cativeiro como em vida livre, a resposta de alerta a um estimulo fazia o animal parar, posicionar-se em postura de alerta - com as quatro patas no chão, tórax levemente inclinado e a cabeça para frente - e vocalizar. Os demais animais por vezes corriam para o abrigo, no entanto, em algumas ocasiões não houve nenhuma alteração visível no comportamento de alguns animais do grupo.

Nas gravações de animais em vida livre, o chamado de alarme foi bastante comum, ocorrendo surtos geralmente longos (alguns superando 10 minutos), ao invés de notas isoladas. 0 grupo observado na Fazenda Tamanduá parecia ter uma preferência por uma parte específica do rochedo que habitava, já que em todos os episódios registrados o emissor estava posicionado nesse 'posto de observação'. É interessante notar que dos 7 episódios em que o assobio de alarme foi registrado em FT, nos 5 dias de observação, o emissor foi sempre uma fêmea (reconhecida pela marca feita no cativeiro, antes da soltura, ou pela visível ausência de testículos). Também em um dos dois surtos registrados em SF, São Mamede, pudemos perceber que o animal emissor era uma fêmea, pela ausência de testículos; no segundo surto o animal vocalizou por entre madeiras que se encontravam sobre a rocha e não conseguimos saber o sexo.

0 chamado de alarme também foi registrado em PA de animais do mesmo sexo, uma em MM e outra em FF. Ocorreu em situações que pareciam representar disputas de espaço ou conflitos de dominância, ao invés de

resposta a estímulos associados a predadores potenciais. É interessante 
notar que embora o contorno da modulação de frequência seja muito parecido com o da vocalização obtida em GR e VL, há diferenças espectrais, como no número de harmônicos, e, principalmente, temporais. Em GR e VL, os surtos eram longos (um dos episódios durou mais do que 10 minutos, enquanto em PA durou um pouco mais do que 3 minutos) ou constituíam-se de notas isoladas. Nas situações - GR e VL, não ficou claro para nós se a informação que fomenta a fuga dos receptores (outros animais do grupo) esta relacionada a frequência, intensidade das notas ou ao ritmo empregado nas frases, pois presenciamos fuga em episódios com a emissão de apenas uma nota e também em episódios onde os receptores fugiram após o aumento do ritmo das frases.

Tabela 8: A estrutura física do Assobio de alarme de $K$. rupestris emitido nas três condições de coletas. As medidas estão representadas pela média (desviopadrão) e mínimo-máximo. Apresenta-se também o número amostral $(\mathrm{N})$ de notas usadas para essa descrição. A duração está expressa em segundos e as medidas de frequência em $\mathrm{kHz}$.

\begin{tabular}{|c|c|c|c|c|c|c|}
\hline & $\mathrm{N}$ & $\begin{array}{l}\text { Duração das } \\
\text { notas }\end{array}$ & $\begin{array}{l}\text { Frequência } \\
\text { Mínima }\end{array}$ & $\begin{array}{l}\text { Frequência } \\
\text { Máxima }\end{array}$ & $\begin{array}{l}\text { Frequência } \\
\text { Dominante }\end{array}$ & $\begin{array}{l}\text { Número de } \\
\text { Harmônicos }\end{array}$ \\
\hline \multirow{2}{*}{ PA } & \multirow{2}{*}{50} & $0,04(0,01)$ & $1,1(0,2)$ & $6(1,9)$ & $2,5(0,3)$ & $4,2(1,7)$ \\
\hline & & $0,02-0,07$ & $0,8-2$ & $1,5-13,2$ & $1,2-3,3$ & $4-11$ \\
\hline \multirow{2}{*}{ GR } & \multirow{2}{*}{29} & $0,14(0,35)$ & $0,8(0,3)$ & $4,7(2,1)$ & $2,1(0,3)$ & $3(1,6)$ \\
\hline & & $0,04-2$ & $0,04-1,7$ & $1,3-1,1$ & $0,6-2,7$ & $1-7$ \\
\hline \multirow{2}{*}{ VL } & \multirow{2}{*}{108} & $0,06(0,06)$ & $1,1(0,2)$ & $4,5(1,3)$ & $2,2(0,2)$ & $2,9(1,6)$ \\
\hline & & $0,04-0,77$ & $0,7-1,4$ & $1,9-1$ & $1,7-3$ & $1-9$ \\
\hline
\end{tabular}

\subsubsection{Ganido}

\section{Squeak (Galea, Lacher, 1981)}

Essa vocalização, como o nome indica, se assemelha a um ganido de um cão. Ocorreu nas situações PA e GR após a recebida de uma investida agressiva, situação semelhante ao attack lunge, descrito por Lacher (1981). 0 agredido emite esse sinal enquanto foge em submissão ao agressor. 


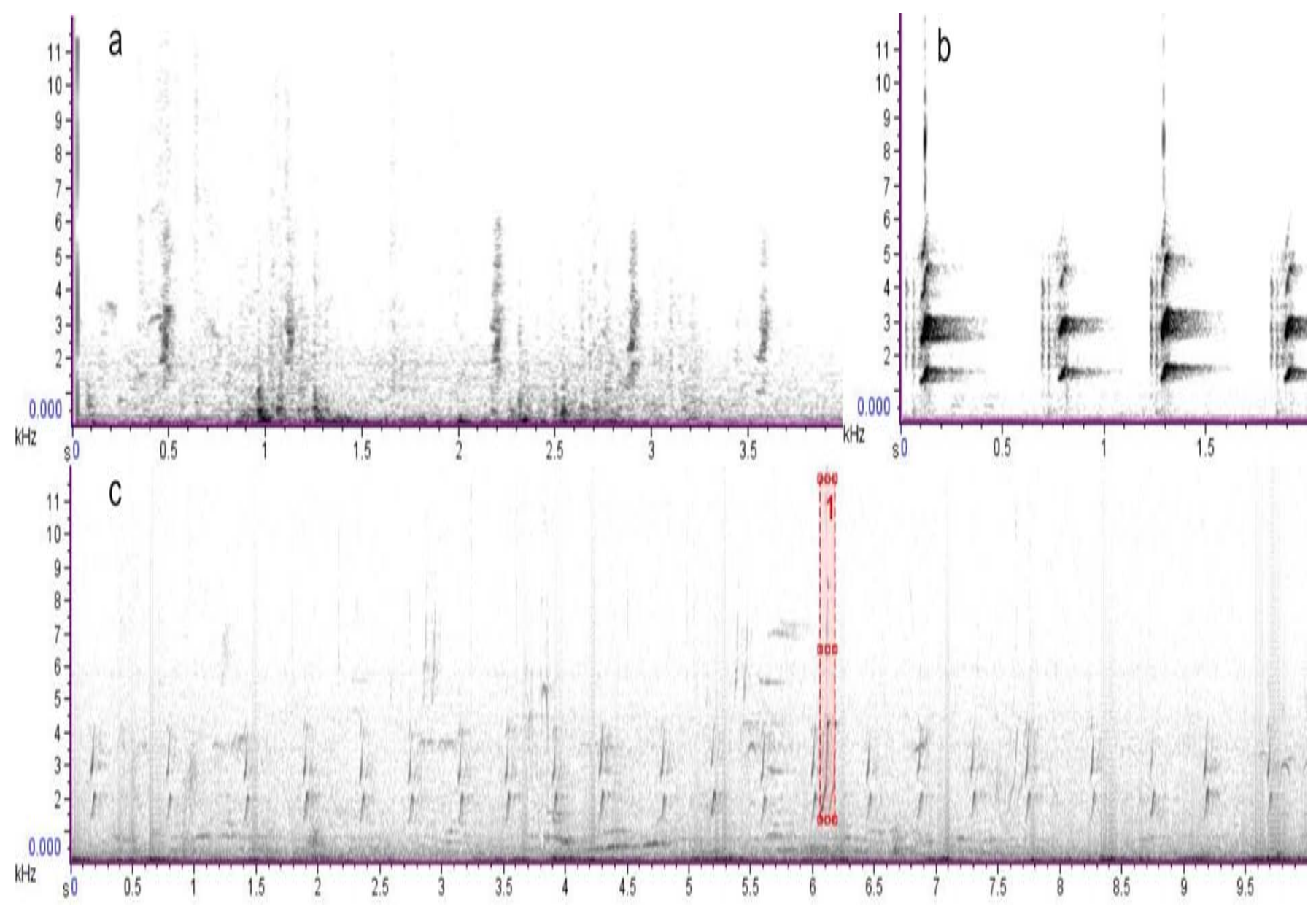

Figura 13: Três sonogramas do Assobio de alerta. (a) Frase curta de 6 notas na faixa de 1,5kHz e 6kHz. (b) Recorte de 4 notas (2s) da sequência mostrada em (c), aumentada 4 vezes para mostrar as notas em detalhe. (c) Frase de 10 segundos com 22 notas. 0 retângulo vermelho mostra uma vocalização de uma ave entre as notas de latido do mocó. 
Constitui-se de surto (frequentemente agrupadas em frases) com notas variadas em relação à duração e modulação de frequência. As notas que compõem o Ganido são variadas, com algumas notas roucas e outras apresentando estruturas tonais. Notamos que algumas notas que compõem esse sinal sonoro também ocorrem em outras vocalizações, como no chorinho. No entanto não caracterizamos como sendo a mesma vocalização diante das diferenças marcantes de contexto e composição das frases. Em media, as notas duraram $0,17 \mathrm{~s}$ frequência mínima em $0.5 \mathrm{kHz}$, máxima em $3.9 \mathrm{kHz}$ e dominante em $1.2 \mathrm{kHz}$. 0 numero médio de harmônicos foi 3,7.

0 sonograma da Figura 15 refere-se a uma frase produzida em uma sessão de PA. Observa-se uma primeira nota de curta duração com modulação de freqüência ascendente semelhante à da primeira nota da vocalização, Chorinho mostrada no sonograma da Figura 10. A segunda nota apresenta estrutura tonal e tem duração longa iniciando sem modulação de frequência, seguida por leve ascendência, obtendo sustentação até finalizar com leve descendência. A terceira nota possui modulação de frequência oscilante que se mantém até o final. A quarta nota é uma repetição da nota 3. O sonograma da figura $14 \mathrm{~b}$ embora possua duas notas distintas do Ganido da figura 14a, entendemos como mesmo sinal sonoro diante do contexto bem caracterizado (fuga após agressão). Entre as 3 notas que compõem essa frase, a nota 1 é a única que se difere da figura a, iniciando com modulação de frequência ascendente, seguida por uma fase descendente, voltando a ascender e ganhar uma breve sustentação para em seguida descender e finalizar. 


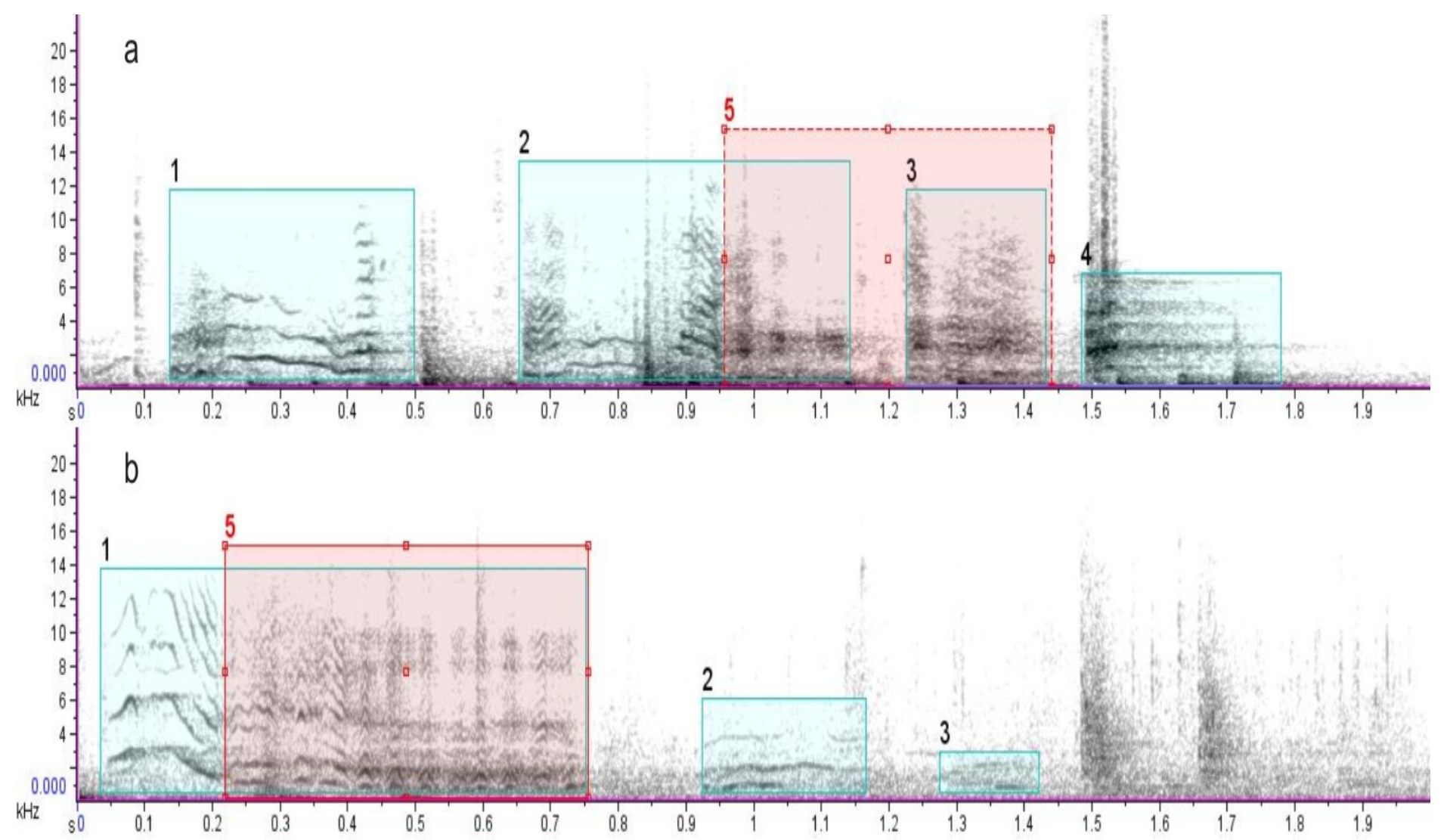

Figura 14: Sonogramas de Ganidos emitidos (a) PA: frase com 4 notas (retângulos verdes) estruturalmente variáveis de até $14 \mathrm{kHz}$. 0 retângulo vermelho mostra a semelhança entre o final da nota 2 com a nota 3 e (b) GR: frase com 3 notas (retângulos verdes) também de estrutura variável, a primeira, com faixa de frequência maior, atingindo os $14 \mathrm{kHz}$. Os retângulos vermelhos de número 5 mostram um elemento característica do ganido que pode ser emitido como uma nota isolada (3, em a) ou como partes finais de outras notas (final de $2 \mathrm{em}$ a, e final de 1 em b); sua estrutura é de um estacato, isto é, uma sequência de Us invertidos sem intervalo. 


\subsubsection{Grito}

Trata-se de uma vocalização muito rara, obtida em apenas dois paramentos por um animal que foi atacado e se afastou, apressadamente, do agressor. As duas agressões aconteceram quando os animais se esbarraram em um local da caixa, e um subjugou o outro.

Nos dois casos aqui registrados, o grito correspondeu a notas com estruturas tonais. A figura 15 apresenta uma primeira sem modulação de frequência, assim como a segunda nota, já a terceira nota apresenta modulação de frequência iniciando em leve ascendência, terminando com descendência brusca.

\subsubsection{Arfar}

\section{Nasal hiss (Lacher, 1981)}

Essa_emissão ocorreu em situações agonísticas e recebeu esse nome, pois sua sonoridade nos remete à lembrança de um "homem" ofegante após esforço físico. Em média, as notas duraram $0,10 \mathrm{~s}$, tiveram frequência mínima em $1,7 \mathrm{kHz}$, máxima em $11 \mathrm{kHz}$ e dominante em $3,4 \mathrm{kHz}$. No sonograma (Figura 16a) as notas são roucas, não é possível notar estrutura tonal com modulação de frequência. 


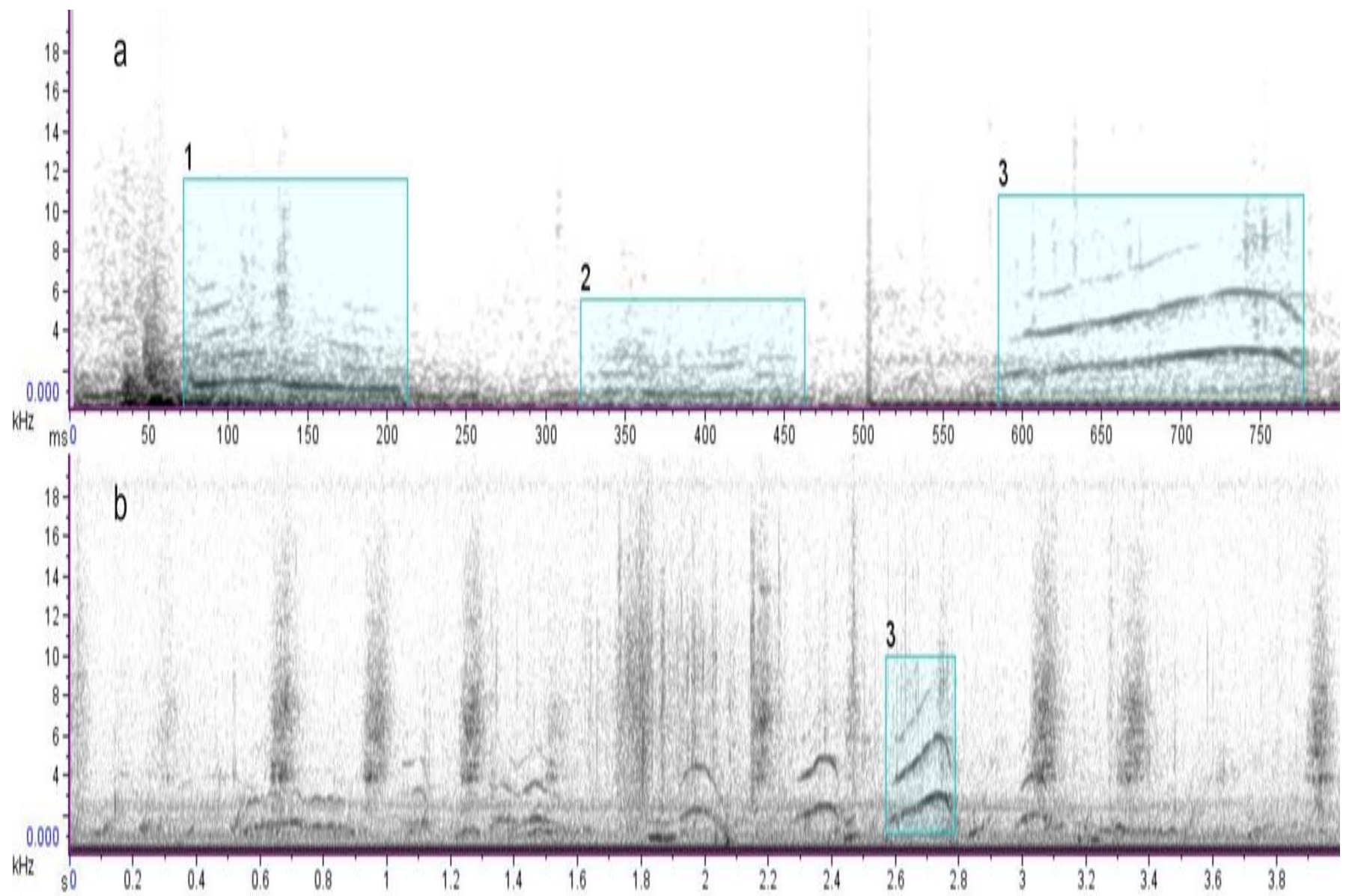

Figura 15: Sonograma de frases de Grito. (a) 3 notas (retângulos verdes enumerados) emitidas pelo macho Beto quando pareado com Manuel. (b) Frase de 3 notas (marcamos apenas a 3aㅗ delas), emitida após Chorinho por uma fêmea pareada com outra fêmea. Nota-se o Arfar da fêmea agressora sobrepondo-se às vocalizações da agredida. 


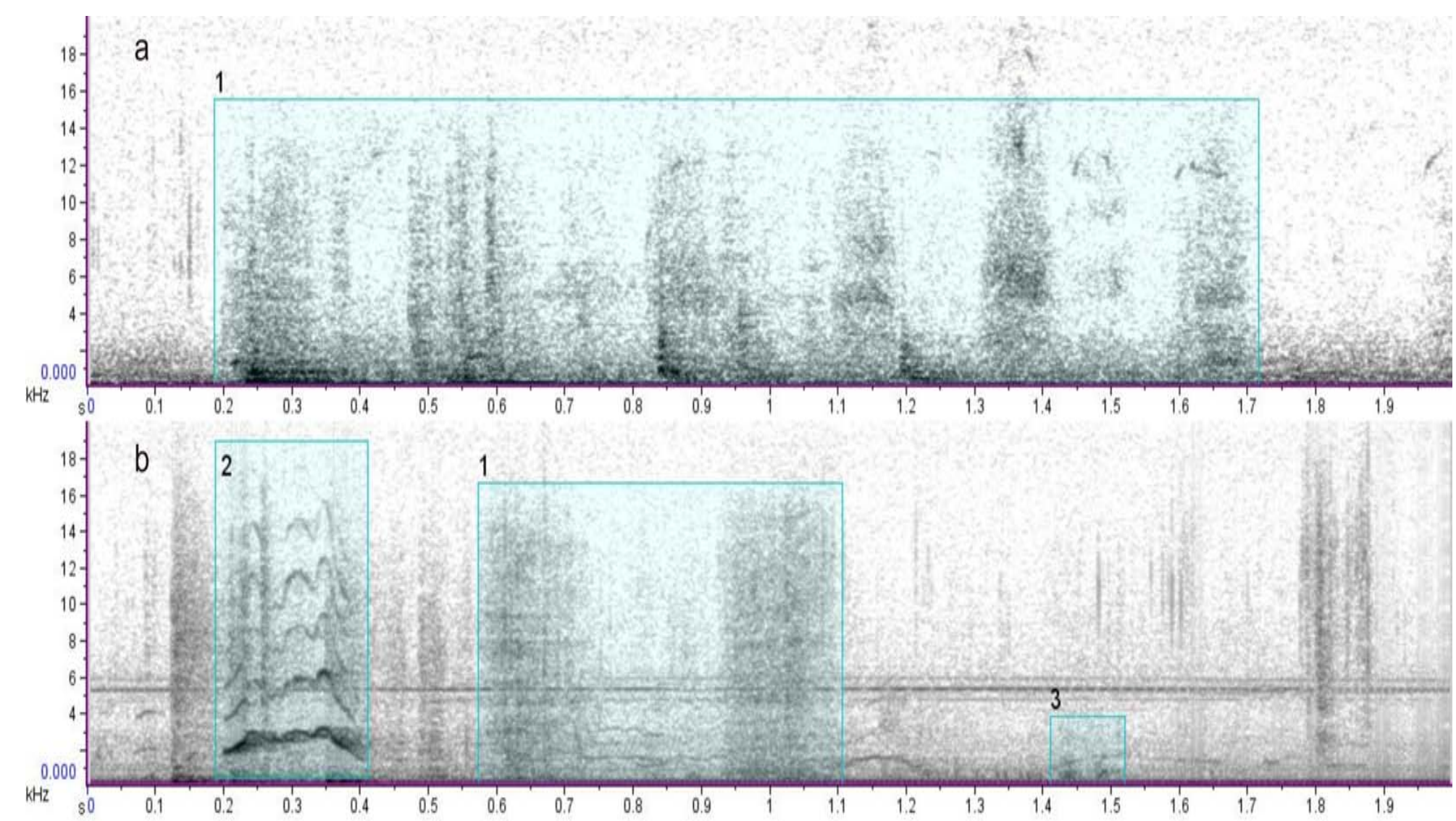

Figura 16: Sonograma de Arfar. (a) Uma frase de aproximadamente 1,5 segundos apresentando seis notas (colunas mais escuras dentro do retângulo verde). (b) Sequencia emitida por dois animais simultaneamente: inicia-se com uma nota de ganido (2), seguida de duas notas de arfar (1) sobrepostas com Chorinho (3 mostra apenas uma nota de Chorinho). 


\subsubsection{Có}

Utilizamos aqui também uma onomatopéia para nomear esse sinal sonoro, aproveitando trabalhos prévios do nosso laboratório (Monticelli, 2005). É emitido quando os animais forrageiam e ou quando são expulsos do local que estavam se alimentando após uma rápida investida de um animal maior, o animal expulso fugia emitindo esse sinal sonoro até encontrar um novo ponto de alimentação.

Essa vocalização apresentou-se como notas isoladas e em frases compostas por duas notas que apresentam estrutura tonal. Em media, as notas duraram $0,08 \mathrm{~s}$, com frequência mínima em $0,5 \mathrm{kHz}$, máxima em $0,8 \mathrm{kHz}$ e dominante em $0,7 \mathrm{kHz}$ (Figura 17).

\subsubsection{Ronco}

Vocalização emitida em situações agonísticas, quando um animal sofre investida agressiva de outro, por disputa de território. Nessa situação o animal emissor é aquele que perde a disputa e foge, se recolhendo em um local oposto à posição do vencedor. Nesse momento, é possível ouvir esse sinal sonoro que, pode evoluir ou não para o chamado de alerta descrito na situação de pareamento.

O ronco é uma vocalização de fácil identificação ao ouvido humano. Ao sonograma (figura 18), mostra-se como uma nota rouca. Em média, as notas duraram 0,12 s, tiveram frequência mínima e máxima de 0,3 kHz e 6,5 kHz, respectivamente e frequência dominante foi em $1,6 \mathrm{kHz}$ 


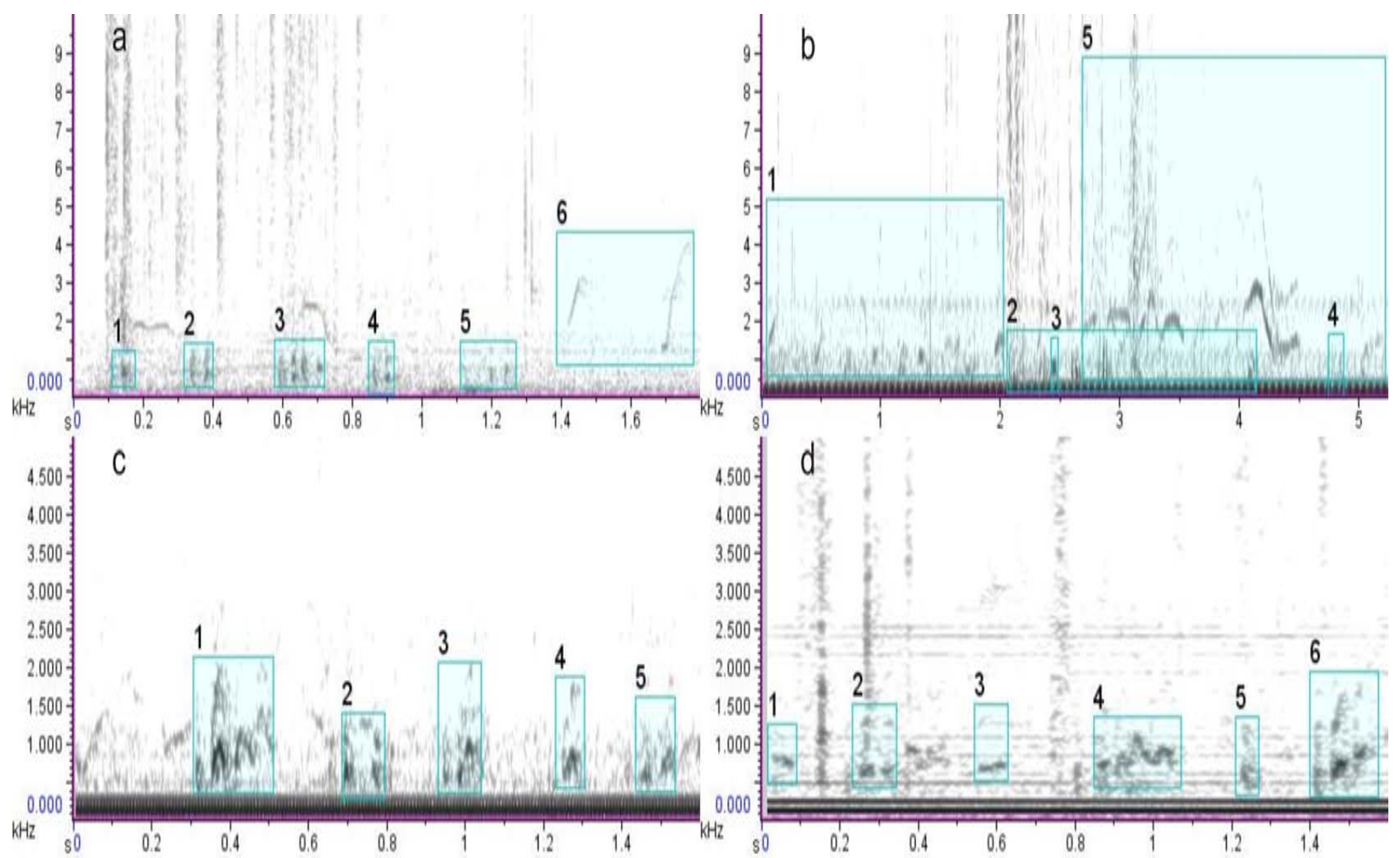

Figura 17: Sonogramas de Có. (a) frase de có (retângulos verdes 1-4) 2, 5 e 6 transição para chorinho. (B) Có (retângulo 1,2 e 3), 4 e 5 vocalizações de outros animais sobrepondo o Có. (c) 5 frases de chorinho sendo o retângulo 1 mostrando frase composta por 4 notas e os demais com frase de 2 notas. (d) os retângulos pares mostram vocalização Có e os impares mostram o Chorinho emitidos por outros animais do GR. 


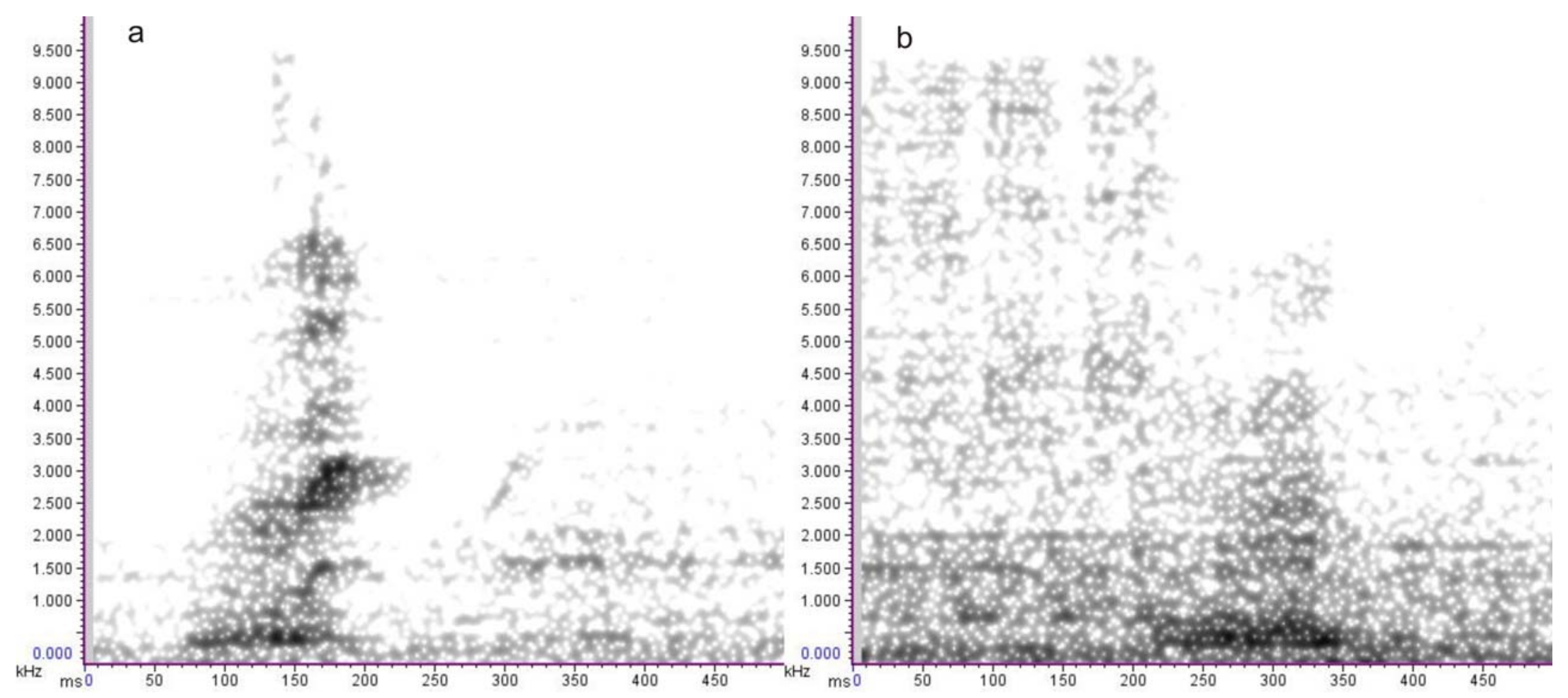

Figura 18: Sonograma de Ronco com 0,5 segundo de duração. (a) representação de 1 nota ocupando faixa de frequência de 0,3-9,5kHz. (b) Representação da mesma nota com menor grau de ruído de fundo. 


\subsubsection{Silvo}

Este sinal foi raro em nossos registros (um surto) e emitido por animais escondidos por entre as fendas das rochas e emitido nos primeiros dias de gravação dos animais em VL e no início dos registros, assim que chegamos ao rochedo. Foi emitido sem que os animais estivessem no campo de visão e não conseguimos identificar o emissor.

Trata-se de um som agudo, tonal com leve modulação de frequência e sem harmônicos acima da fundamental. As notas têm, em média, 1,31 s de duração e apresentam-se aos pares (frases), iniciam-se em 6,3 kHz, acabam em 7,5 kHz e têm frequência dominante em 6,9 kHz.

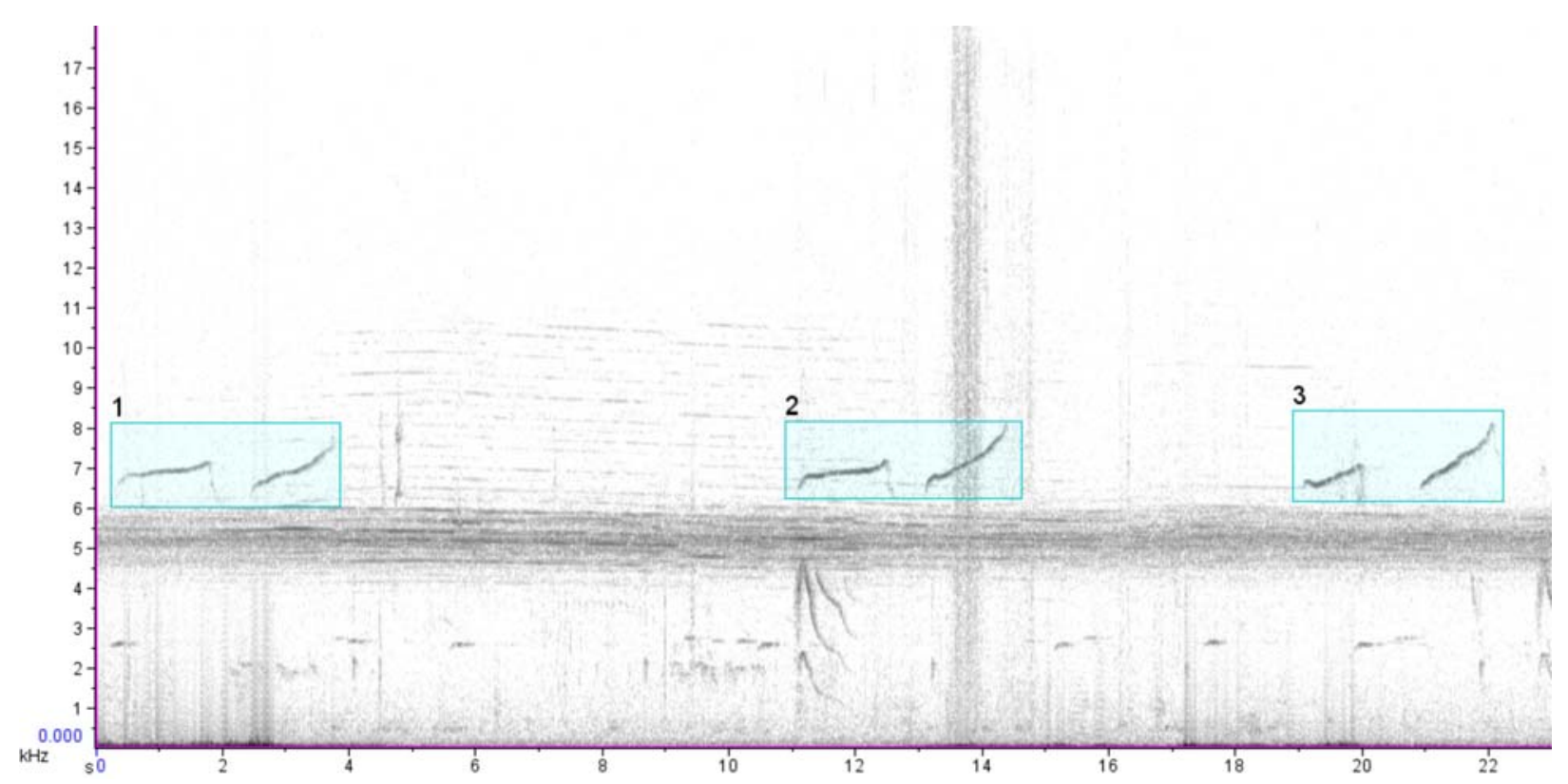

Figura 19: Sonograma de Silvo de 23 segundos apresentando um surto com 3 frases com um par de notas (retângulos verdes numerados) cada. As notas tem duração aproximada de 2 segundos (cada), ocupando faixa de frequência de 6 a $8 \mathrm{kHz}$. 


\subsubsection{Bater-de-dentes ou Entrechoque-de-incisivos}

\section{Tooth-chattering (Arvola, 1974; Lacher, 1981),}

É uma emissão não-vocal produzida pelo atrito entre os dentes incisivos e que acompanha os encontros agonísticos. Precede as investidas agressivas e em algumas vezes os animais ficam frente a frente emitindo o entrechoque, no entanto esse sinal pode surgir sem a necessidade da encarada. As frases foram longas, algumas com mais de 10 segundos de duração. A sua grande maioria foi obtida em PA e uma única vez em VL, quando os animais estavam fora do nosso campo de visão (Figura 20b).

0 sinal é rouco formado por pulsos repetidos a intervalos regulares, apresentando-se visualmente no sonograma como colunas que ocupam uma ampla faixa de frequência $(0,5 \mathrm{kHz}$ até $21 \mathrm{kHz})$ com duração média de nota de $0,04 \mathrm{~s}$ com médias de frequência mínima e máxima de $0,6 \mathrm{kHz}$ e $8,5 \mathrm{kHz}$ respectivamente e frequência dominante média de $1,2 \mathrm{kHz}$. 

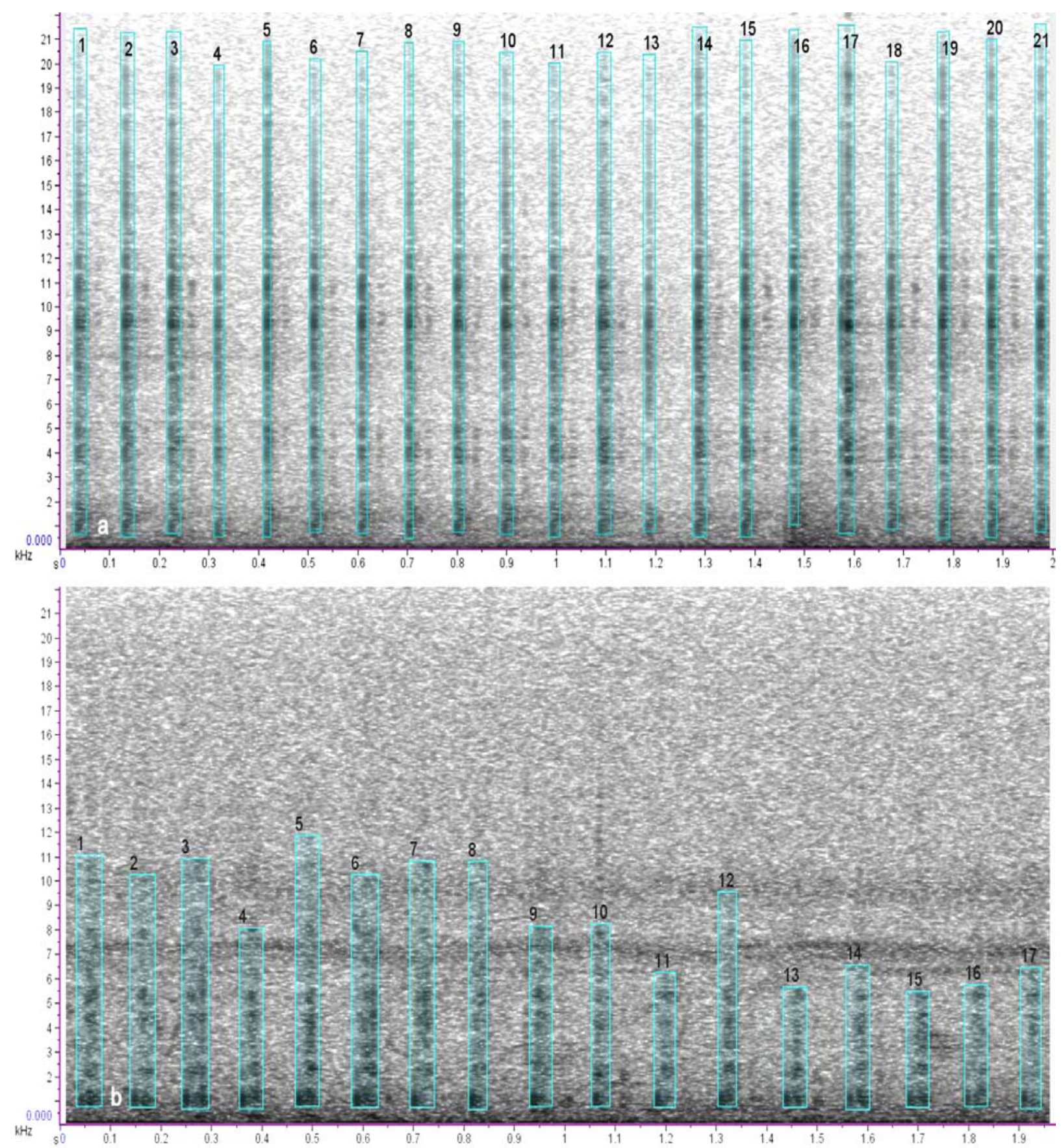

Figura 20: Sonograma de entrechoque de incisivos. (a) PA: Frase de 2 segundos apresentando 21 notas (retângulos verdes numerados) ocupando faixa de frequência de 0,5 a $21,5 \mathrm{kHz}$ e (b) VL: frase de 2 segundos apresentando 17 notas (retângulos verdes numerados) ocupando faixa de frequência $0,5 \mathrm{a} 12 \mathrm{kHz}$. 


\subsection{Outros chamados}

Deixamos aqui um sinal que registramos sem ter o emissor em nosso campo de visão e que por isso não temos certeza de que foi produzido e de que constitui um sinal de comunicação de K. rupestris.

\section{Tamborilar}

Esse sinal sonoro aconteceu com os animais em cativeiro (GR) após um indivíduo ser perseguido por outro enquanto o grupo se alimentava. Não foi possível identificar no vídeo os dois indivíduos envolvidos nesse episódio. Mas é possível dizer que se tratava de dois machos. 0 animal subjugado fugiu e se escondeu dentro de uma caixa de madeira disposta dentro do recinto. Alguns instantes após o animal se esconder registramos alguns surtos de uma emissão que tem estrutura sonografica e que soa como o tamborilar descritos para a Galea spixii (Lacher, 1981). Em Gálea, o tamborilar é produzido batendo-se as patas traseiras contra o solo. Ouvimos três sons que lembram batidas rápidas em uma superfície rígida que poderia ser a madeira da caixa que o fugitivo usou de abrigo. Nesse episódio também é possível ouvir a vocalização Ronco, que já descrevemos como sendo comum de encontros agonísticos o que pode fortalecer a possibilidade de estarmos diante de um sinal sonoro que é típico de uma situação estressante para o animal, como a introdução a um novo ambiente ou expulsão do local de alimentação por um animal maior e com pouca área de fuga, como observamos. 


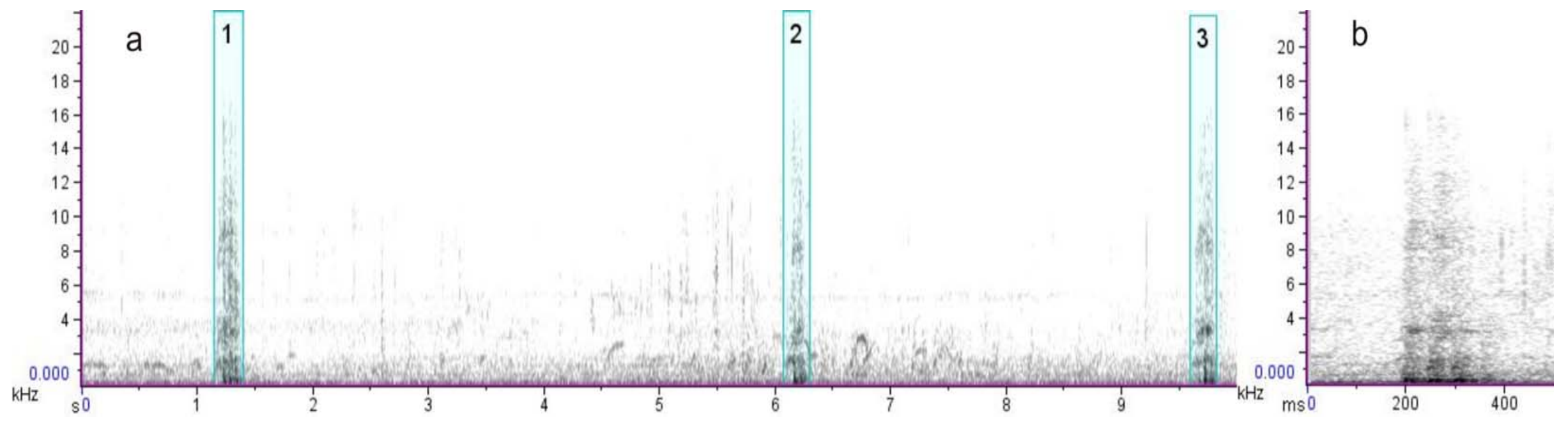

Figura 21: Sonograma de Tamborilar: (a) Frase de Tamborilar composta por três notas (retângulos vedes numerados). (b) Um única frase de três pulsos (notas; vê-se como três colunas com intervalos muito curtos). 


\section{DISCUSSÃO}

Nosso trabalho foi fazer um levantamento dos sinais acústicos que compõem o repertório da espécie de mocó da caatinga, Kerodon rupestris. Para que ele fosse o mais completo quanto possível, coletamos dados em situações de interações forçadas, em cativeiro e em ambiente natural. Como resultado, descrevemos 11 sinais e sugerimos que o Tamborilar seja o $12^{\circ}$ sinal, como será discutido mais abaixo. É possível que outros sinais venham a ser descritos quando se estudar as interações entre adultos e filhotes e as respostas de filhotes à situação de isolamento social ou da mãe, já que nossa amostra foi apenas de animais adultos. Começaremos discutindo aspectos da nossa amostra de animais e então abordaremos aspectos ecológicos e filogenéticos da comunicação acústica no mocó.

\section{Idade e variação sexual em medidas morfométricas}

Pelo critério de Lessa e Pessoa (2005) de determinação de faixa etária através das medidas de comprimento e largura zigomática de crânio, todos os nossos animais eram adultos (idade 5 de Lessa e Pessoa: comprimento

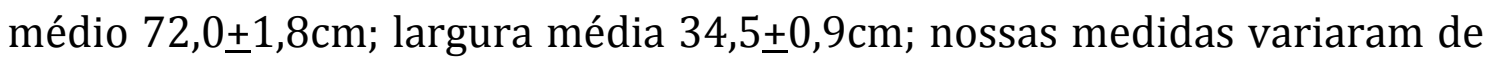
73 a $90 \mathrm{~cm}$ em comprimento, e de 31 a $38 \mathrm{~cm}$ em largura). Também em relação ao peso, nossos animais se enquadram na categoria de animais sexualmente maduros (a partir de 500g e de 3 meses de vida, Lacher 1981; Lessa \& Pessoa 2005; nossas medidas variaram de 490 a 905g, Tabela 4).

Se eram todos animais sexualmente maduros, e se há na espécie cio pós-parto (Lacher 1981), por que nossas fêmeas não estavam grávidas? Essa é uma pergunta interessante para qual haveriam três respostas. Elas poderiam estar grávidas, no início da gestação, mas o tempo em cativeiro foi menor do que o tempo de gestação e por isso não registramos nascimentos. 
Não confiamos nessa hipótese porque nem mesmo no dia da soltura, quando as tínhamos nas mãos, havia qualquer aumento do abdômen ou alteração das mamas. A segunda explicação seria um viés na captura: como trabalhamos só com duas armadilhas e as colocamos em apenas dois locais, poderíamos ter favorecido a captura de fêmeas periféricas da colônia, que não tivessem tido oportunidade recente de se acasalar. Também não temos informações na literatura que sustentem isso. A hipótese que tem algum embasamento é que tenha havido reabsorção do feto, em decorrência do estresse agudo decorrente do procedimento de captura e realocação em ambiente não familiar. Ainda, embora os animais que formaram o grupo cativo fossem, provavelmente, familiares (já que foram capturados em um mesmo rochedo), as relações entre eles poderiam não ser afiliativas. Lacher (1981) relata a absorção de feto em Galea spixxi, espécie que ele acredita ter um ancestral comum com Kerodon, e nós comprovamos isso em analises patológicas macroscópicas (necropsias) de fêmeas de Cavia aperea (dado não-publicado, PFM).

Embora nossa amostra seja pequena e não tenhamos feito uma comparação estatística das diferenças entre os sexos, as fêmeas tiveram algumas medidas ligeiramente maiores do que os machos: comprimento de

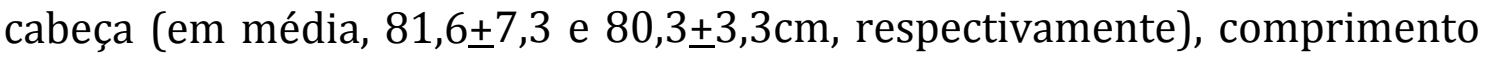
de corpo (em média, $324,0 \pm 24,7$ e valor máximo $360 \mathrm{~cm}$ para fêmea; em média, $323,0 \pm 19,2 \mathrm{~cm}$ e valor máximo $340 \mathrm{~cm}$ para macho), e peso médio $(81,6 \pm 7,3$ e $80,3 \pm 3,3$, respectivamente, sendo o maior valor registrado de um macho de 905g). A maior diferença entre os sexos foi no comprimento do pé, em média e em valor máximo, maior em machos $(61,8 \pm 5,2 \mathrm{~cm}$ e 57 $71 \mathrm{~cm}$ em machos; $58,7 \pm 3,6 \mathrm{~cm}$ e $53-64 \mathrm{~cm}$ nas fêmeas).

Essas diferenças entre os sexos são curiosas por serem contrárias a Lessa e Pessoa (2005). Os autores estudaram 188 crânios de indivíduos provenientes do Município de Campos Sales no Ceará, do acervo do Museu Nacional, coletados entre 1952 e 1955 pelo Serviço Nacional da Peste. Esses 
autores descrevem um dimorfismo sexual de crânio pouco acentuado, mas a favor dos machos. A diferença entre nossa amostra e a desses autores poderia refletir, novamente, um viés de captura. Talvez os machos menores fossem os que mais se locomoveram pelo rochedo, por ficarem mais periféricos, ou que as fêmeas maiores fossem as que, por algum motivo, se locomovem mais, e isso aumentaria a probabilidade de que essa amostra de animais caísse nas armadilhas. Achamos, contudo, que a variação de peso e das outras medidas sustenta a hipótese de que nossa coleta tenha coberto uma amostra bem variada de animais. Além disso, nem se sabe se existe essa organização periférica de animais nesse grupo social. Talvez a diferença reflita uma diferença populacional entre Ceará e Paraíba e merece ser melhor avaliada.

\section{O repertório acústico (total) do mocó}

Ao estudar o comportamento de mocós (K. rupestris) em cativeiro, Lacher (1981) fez uma descrição superficial e qualitativa de suas vocalizações. Segundo ele, filhotes emitem Peepy squeaks, que devem corresponder ao Chorinho que descrevemos aqui, quando interagem com fêmeas adultas; e emitem também um assobio (Slow whistle) que não descrevemos aqui, ou não com esse nome. A descrição desse autor é muito vaga e não nos permite saber se esse assobio poderia corresponder a alguma das categorias que descrevemos. As que melhor se aproximariam de uma estrutura de assobio lento (modulação ascendente de frequência longa e gradual, não-abrupta) seriam o Silvo ou, menos provavelmente, uma variante de Chorinho (por exemplo, as penúltimas notas - 9 e 10 - da Figura 10, apresentada em Resultados; elas têm estrutura de assobio, mas a modulação é abrupta e não lenta).

Em relação ao contexto de emissão, o autor registrou essa vocalização em filhotes quando a mãe deixava os rochedos para se alimentar; e por adultos, em situações que causariam ansiedade, como por animais prestes a 
deixar a proteção dos rochedos para forragear. Registramos o Silvo a partir de animais escondidos por entre as fendas das rochas, quando o experimentador (RNAJ) os observava há alguns metros do rochedo. Estudos futuros e experimentos com playback poderiam aumentar a amostra de Silvos e testar se seriam usados no contexto sugerido por Lacher.

Independente de corresponder ou não o assobio lento de Lacher ao Silvo ou a outra vocalização, é irresistível a comparação da descrição desse autor com o que conhecemos sobre os assobios do preá e da cobaia doméstica (Tabela 9; Monticelli 2005; Monticelli \& Ades submetido). Filhotes de preás e de cobaias (e de capivaras, Barros et al. 2011; Tabela 9) assobiam quando estão distantes de suas mães. Apenas cobaias, adultas ou filhotes, emitem um assobio semelhante ao ouvido, em antecipação à entrega de alimento por um tratador humano (Monticelli et al. 2009). Observando cobaias vivendo em grupo em um semi-cativeiro (um cercado aberto de $10 \mathrm{~m}^{2}$, construído em área de mata-atlântica, no município de Itapevi, sujeito à predação) notamos a emissão de assobios por animais de todas idades de forma muito semelhante ao que Lacher chama de rede de comunicação (communication web): os animais assobiavam ao mesmo tempo enquanto saiam lentamente dos abrigos em direção ao estimulo que tivesse sinalizado a entrega de alimento (observação pessoal de PFM, não publicada). A existência de um assobio em mocó, usado tanto por filhotes isolados como por adultos antes da saída para forragear em ambiente aberto, enriquece a discussão sobre a origem e função do assobio-aotratador da cobaia. Até então, trabalhava-se com a hipótese de o assobio, que desaparece do repertório de adultos na espécie selvagem, fosse um efeito da domesticação e até um sinal selecionado pela interação com o ser-humano (Monticelli et al. 2009). Os assobios da cobaia são apenas um exemplo da contribuição que a continuação desse estudo comparativo entre repertório acústico de cavídeos pode trazer. 
Tabela 9: Comparação entre os repertórios de $K$. rupestris e dos cavídeos H. hydrochaeris (capivara), G. spixii (preá-de-denteamarelo da caatinga), C. aperea (preá de maior distribuição geográfica) e C. porcellus (cobaia doméstica). Na comparação, procuramos levar em conta tanto o contexto de emissão como a estrutura geral do sinal. Comentários e nomes originais da literatura consultada estão entre parêntesis. (?) indicam comparações que ainda merecem ser analisadas em mais detalhe. (NÃ̃o OBSERVADO) indica situações nas quais não se pode dizer que não sejam acompanhadas por emissões pela falta de oportunidade dos autores em acompanhá-las.

\begin{tabular}{|c|c|c|c|c|}
\hline Contexto & Kerodon & $\begin{array}{l}\text { Hydrochoerus hydrochaeris } \\
\text { (Barros et al, 2011) }\end{array}$ & $\begin{array}{c}\text { Galea spixii } \\
\text { (Lacher, 1981) }\end{array}$ & $\begin{array}{c}\text { Cavia aperea/C. porcellus } \\
\text { (Monticelli e Ades, submetido) }\end{array}$ \\
\hline \multirow{3}{*}{ Alerta } & Assobio de alarme $=$ Latido & Latido (Bark) & & Chirrup \\
\hline & Drrr & & & Drrr \\
\hline & Silvo? & & & \\
\hline \multirow{5}{*}{$\begin{array}{l}\text { Contato e modulação } \\
\text { social/Forrageamento e Exploração } \\
\text { em grupos }\end{array}$} & Chorinho & & Chorinho (Peepy squeaks) & Chorinho \\
\hline & Drrr & & & Drrr \\
\hline & Có & & & Có \\
\hline & Estalido & Estalido (Click) & & \\
\hline & Silvo? & & & $\begin{array}{c}\text { Tweet } \\
\text { (limpeza ano-genital do filhote) }\end{array}$ \\
\hline Solicitação de Alimento & & (Whine) & & $\begin{array}{c}\text { Assobio-ao-tratador* } \\
\text { (efeito da domesticação?) }\end{array}$ \\
\hline Chamado de corte & NÃO OBSERVADO & NÃO OBSERVADO & & \\
\hline \multirow[b]{2}{*}{ Separação } & \multirow[b]{2}{*}{ NÃO OBSERVADO } & (Cry) & & \\
\hline & & $\begin{array}{c}\text { Assobio (Whistle) de separação } \\
\text { (exclusiva de filhotes) }\end{array}$ & & $\begin{array}{l}\text { Assobio de separação } \\
\text { (exclusiva de filhotes) }\end{array}$ \\
\hline $\begin{array}{c}\text { Ansiedade em separação ou } \\
\text { em local não-familiar }\end{array}$ & Tamborilar? & & Tamborilar (Drumming) & \\
\hline \multirow{6}{*}{$\begin{array}{l}\text { Interações Agonisticas } \\
\text { Indicadores de } \\
\text { Dominância/submissão }\end{array}$} & Assobio de alarme $=$ Latido & & Latido (Bark) & \\
\hline & Ganido & & Grito (Squeak)? & Grito (Squeal)? \\
\hline & Grito & Grito (Squeal) & Grito (Squeak)? & Grito (Scream) \\
\hline & Ronco & & & Cru-cru \\
\hline & Arfar & & Arfar (Stutter) & \\
\hline & Bater-de-dentes & $\begin{array}{c}\text { Bater-de-dentes } \\
\text { (Cackle + Tooth-chatter) }\end{array}$ & Bater-de-dentes (Tooth-chatter) & Bater-de-dentes \\
\hline Total & 12 & 7 & 6 & $10^{*}$ \\
\hline
\end{tabular}

$\left(^{*}\right) 0$ assobio-ao-tratador não está embutido no total de sinais do repertório de Cavia, por ser exclusivo da espécie domesticada. 
Um repertório de 12, talvez 13, sinais é algo notável entre roedores (Eisenberg 1974) e comparável aos repertórios de algumas espécies de primatas como o Mandrillus sphinx, o Cebus olivaceus e o Callicebus moloch (McComb \& Semple 2005).

Entre os roedores, os caviomorfos, grupo ao qual pertence o mocó, o préa e a capivara, são os que fazem um uso intenso do canal acústico para comunicação, dentre as espécies que já foram estudadas. Essas três espécies fazem parte de uma mesma família, Caviidae, compartilham sinais e quase se assemelham em tamanho de repertório (Tabela 9). Para preás e cobaias, gênero Cavia, foram descritos 10 sinais, metade deles estruturalmente semelhante aos chamados descritos aqui pelo mesmo nome, no mocó (Monticelli 2005; Monticelli \& Ades submetido). São eles o Drrr, o Bater-dedentes, o Chorinho, dois tipos de Grito, um aparentemente equivalente ao Ganido e o Chamado de contato (Có). É inquestionável a semelhança estrutural e contextual entre esses 6 sinais comuns às duas espécies. Além deles, há outros dois que diferem em estrutura, mas que, em uma análise apenas superficial, se assemelham em relação à situação de emissão: o Crucru de machos preás em relação ao Ronco do mocó, e o Chirrup (ou Song, Arvola 1974) de cobaias e preás em relação ao Latido de alarme do mocó. Além deles e dos Assobios de cobaias e preás discutidos acima, preás teriam (1) um assobiozinho muito discreto ao ouvido, sem harmônicos, na faixa de 0,5 a $5 \mathrm{kHz}$, representado pela onomatopeia Tweet (Berryman 1976), e (2) um chamado de corte característico do gênero Cavia, o Purr. Como não tivemos a oportunidade de acompanhar mães e filhotes interagindo, não podemos afirmar nem descartar a produção de Tweet ou de outro sinal análogo em mocós, emitido no contexto específico de limpeza ano-genital. Lacher não descreveu nada que se assemelhasse ao Tweet, mas também não acreditamos que ele tivesse sido capaz de notá-lo, sem um equipamento adequado de gravação. 
Estamos, contudo, mais seguros para dizer que os mocós não usam sinais específicos de corte, como as cavias o fazem. Dizemos isso com base em nossas observações e nas de Lacher (1981) que acompanhou animais por mais tempo, em grupos maiores e teve filhotes nascidos em cativeiro. Há uma diferença interessante entre Cavia e Kerodon que explica a presença de exibições-de-corte (rumba, King 1956) na primeira, mas não em mocós. Embora ambas tenham sido descritas como espécies poligâmicas, o macho preá defende diretamente as fêmeas de seu harém contra outros machos, enquanto o macho mocó defende recursos valiosos, objetos de escolha da fêmea (Asher et al. 2008; Asher et al. 2004; Monticelli \& Ades 2003Lacher 1981). Voltaremos a isso mais abaixo.

Em relação à capivara, o único estudo quantitativo apontou a existência de 7 sinais funcionalmente categorizados como alerta, contato e coesão, isolamento (e distress) e agonístico (Barros 2009; Barros et al. 2011). Os autores acham provável que o repertório seja maior do que isso, visto que há vocalizações que acompanham a corte e acasalamento e que não foram observadas nesse estudo de cativeiro. Quatro desses 7 sinais se assemelham à sinais que descrevemos para o mocó ou em relação à estrutura e a função - Estalido, Grito e Bater-de-dentes, ou em relação à função - Latido (Tabela 9).

Entendemos que o compartilhamento de sinais sonoros entre os mocós, as capivaras e os preás (C. aperea), possa elucidar questões filogenéticas que ainda não estão claras dentro do grupo dos roedores histricognatas. A revisão taxonômica atual (Woods \& Kilpatrick 2005) considera Kerodon como pertencente à subfamilia Hydrochoerinae, ao lado das capivaras e mais distante dos preás, do que a classificação tradicional (Caviinae: Kerodon, Cavia, Galea e Microcavia, Quintana et al. 1998; Woods 1993). Embora na classificação atual mocó e capivara estejam mais próximos e haja emissões sonoras compartilhadas pelos dois animais, há um número maior de emissões compartilhadas por mocós e preás (Tabela 9). 
Além disso, embora o Estalido seja estruturalmente comparável entre capivaras e mocós, o contexto de emissão não é (hoje) o mesmo para as duas espécies.

\section{O repertório acústico associado à vida social do mocó}

Dos onze sinais sonoros encontrados no repertório de $K$. rupestris, 4 foram emitidos no contexto de exploração (que englobou comportamentos de contato, coesão e forrageamento), 2 no contexto de alerta e 5, a maioria, no contexto agonístico.

Essa maior proporção de sinais usados em situações agonisticas, que incluíram tanto comportamentos auto-defensivos, como ameaças e ataques, está de acordo com a vida social do mocó. A espécie sobrevive às duras condições do semiárido da caatinga ocupando micro-habitats mais mésicos e fartos, em alimento, que são os rochedos (Barbosa et al. 2005). Os rochedos, contudo não estão bem distribuídos pela caatinga. Ocorrem em ilhas de recursos (manchas) isoladas umas das outras (Lacher 1981). Isso torna possível, em termos de tempo e energia, que um único animal monopolize uma mancha de recurso vital a outros animais e que se instale um sistema de acasalamento baseado em haréns (Lacher 1981).

A poliginia de defesa de recursos é mais comum em aves do que em mamíferos e se associa a um viés sexual de dispersão a favor das fêmeas, segundo Greenwood (1980), quando (1) os machos defendem recursos muito importantes para a aquisição de parceiras sexuais e para a sobrevivência dos filhotes e (2) a possibilidade de conquistar esse recurso é maior na área natal do que aventurando-se em novas áreas. Essas são exatamente as condições ecológicas do mocó e por isso acreditamos que o grupo social do mocó seja um sistema patrilinear. Lacher descreve esse grupo como sendo internamente competitivo, e atribui a alta mortalidade de filhotes à agressão das fêmeas entre si e com filhotes alheios. 0 macho dominante, ao contrário, e reforçando nossa hipótese de organização 
patrilinear, é tolerante com os filhotes e dirige a eles, com frequência, comportamentos de cuidado como amontoar-se e alo-limpeza (huddling e grooming). A tolerância e investimento do macho estaria relacionada ao seu grau de parentesco com eles. As fêmeas competiriam entre si pelos recursos e pela sobrevivência de seus filhotes. Assim, haveria, dentro do grupo, necessidade de comunicar dominância e submissão ou de mostrar-se motivada a atacar (Bater-de-dentes e Ronco) ou a fugir ou render-se (Ganido e Arfar). Os Chorinhos fariam a parte de regulação social, antes da escalonada para comportamentos mais agressivos.

Em preás, ao contrário, há poliginia por defesa de fêmeas, são os machos que dispersam e as fêmeas são tolerantes com filhotes alheios, havendo inclusive cuidado alomaterno em grupos familiares (Asher et al. 2008; Asher et al. 2004; Monticelli \& Ades 2003). Os machos são selecionados diretamente pelas fêmeas por atributos avaliados através de suas exibições de corte ritualizadas de sinais visuais e acústicos (King 1956; Monticelli \& Ades 2011). A agressão dentro do grupo é contida por sinais reguladores sociais (Chorinhos, que são mais frequentes do que em mocós). Normalmente não há machos além do dominante (exceto em alta densidade populacional; Asher et al. 2008).

Em nossas gravações, os chamados agonísticos ocorreram principalmente na situação de pareamentos, quando os animais são forçados a interagir e o afastamento ou fuga, que talvez bastassem para evitar uma agressão, não são possíveis de serem exibidas. Infelizmente não temos informações sobre como o grupo de animais capturados se organizou em cativeiro, a fim de discutir como se distribuíram os comportamentos agonisticos em relação aos papéis sociais de cada sujeito. Teria se estabelecido, como viu Lacher, uma hierarquia linear entre fêmeas? Teria se imposto um único macho dominante (a hierarquia não é linear entre os machos, segundo aquele autor)? Esta é mais uma questão interessante, para uma pesquisa futura. 
Dos 4 sinais agonísticos registrados nessa situação, 3 eram sinais emitidos não por agressores, mas por animais que seriam agredidos: o Ganido, o Grito e o Arfar. A 4⿳a emissão foi o Bater-de-dentes, normalmente emitido pelo animal dominante.

O Ganido foi emitido por animais que sofreram investida agressiva sem necessariamente sofrer a agressão (mordida) e deve servir para demonstrar submissão ou solicitar "misericórdia" a um agressor potencial. Parecem haver sinais equivalentes a esse em roedores heteromídeos como Dipodomys nitratoides, Perognathus calicifornicus e Liomys pictus (Whine squeal, Eisenberg 1963), em outros cavíneos como o porquinho-da-india (Whine Berryman 1976, ou Chorinho, Monticelli 2005). Ao sonograma, o Whine do porquinho-da-índia tem sucessivas modulações de frequência que se assemelham às nossas notas de Ganido. Contudo, o Chorinho da cobaia funciona como um regulador social - uma manifestação de desconforto pela aproximação de um animal, e não como resposta de alguém que acabara de levar um golpe. Nesse sentido, o Squeal de Monticelli \& Ades (submetido) parece ser mais equivalente ao Ganido do mocó. Lacher denominou Squeal o Ganido e o relaciona ao estado motivacional do animal de medo e dor. 0 ganido acompanhou comportamentos como a esquiva (retreat) ou fuga (flee) de Lacher (1981).

0 Grito é uma vocalização associada à dor e à submissão, quando o animal submisso é efetivamente agredido. Berryman (1976) também identificou um chamado que ela denominou Scream no porquinho-da-índia que, contextualmente e ao sonograma, parece análoga ao nosso grito.

O Ronco foi emitido exclusivamente pelos animais quando estavam em grupo, durante perseguição e agressão. 0 emissor eventualmente trocava o ronco pelo Assobio de Alarme (Latido) de contexto agonístico. Lacher (1981), não apontou nenhum chamado parecido com o Ronco. Esta é a primeira descrição dessa emissão que parece acompanhar disputas por 
espaço entre dois animais, e é emitida pelo animal derrotado e com área de fuga restrita.

O Arfar, emitido por animais coagidos pela presença e proximidade de outro na caixa de pareamento, foi descrito por Lacher (1981) como Nasal Hiss em mocós e como Stutter em Galea. Não ficou clara para ele qual a sua função enquanto sinal de comunicação. Talvez essa emissão possa não ter função comunicativa e ser apenas uma emissão relacionada a esforço físico. Essa condição é, contudo, o pano de fundo para a evolução de um sinal de comunicação a partir de uma atividade do sistema nervoso autônomo (Grier \& Burk 1992). 0 surgimento desse sinal em nossos registros se deu após algum tipo de esforço (animais em fuga ou atirando-se contra a tampa da caixa de pareamento). Lacher não o associa a esforço físico e encontrou essa emissão em colônia diferentemente de nós que a registramos apenas nas sessões de pareamentos.

Por fim relacionamos o Entrechoque-de-incisivos, emissão comum a vários roedores em encontro agonísticos (Eisenberg 1963; Lacher 1981; Monticelli \& Ades 2005) e que podem ocorrer sem que ocorra luta, como um sinal ritualizado de propensão em atacar.

Em relação aos chamados de alarme, um Drrr estruturalmente muito parecido, foi descrito como parte do repertório de $C$. aperea por Berrymam (1976) e por Monticelli \& Ades (2011). Para essas autoras, é um sinal de alarme de curta distância. Em preás, também acontece em situações de exploração conjunta do território ou em resposta a aproximação social. Também verificamos isso como mocós: o Drrr ocorreu principalmente no contexto de exploração.

O Assobio de alarme do mocó, que soa como um latido, ocorreu em todas as situações de coleta de dados. Assobios de alarme são bem conhecidos dentro da literatura, especialmente em pequenos mamíferos que vivem em rochas, nos quais a vocalização vem acompanhada da utilização de postos de observação selecionados no micro-habitat (Mares \& Lacher 1987). 
É emitido por suricatas (Manser et al. 2008) e por primatas (Mendes \& Ades 2004) e em particular por pequenos mamíferos especialistas de rochedos (Mares \& Lacher 1987).

Os mocós também utilizam esses postos de observação e o chamado pode ser eliciado não apenas pelo contato visual com o potencial predador. Assim como Lacher (1981), entendemos que esse sinal sonoro possa ser emitido através da detecção do predador pelo olfato. Lacher (1981) também acredita que o som possa eliciar essa vocalização, assim como Barros et al (2011) entendem que sons estranhos eliciem o chamado de alarme de capivaras. No entanto nossas observações não indicaram que sons estranhos estimulem a emissão do chamado de alarme, mas apenas um estado de alerta que pode ou não preceder a vocalização. É especialmente intrigante que o chamado de alarme tenha ocorrido com os animais dentro da caixa de pareamentos numa situação agonística, após agressão. Isso nos leva a pensar que o assobio de alerta ou latido talvez seja um sinal que carregue mais informações do que apenas a presença de predador, como informações sobre um estado de alerta à agressão que venha de um coespecífico; uma demonstração de submissão do animal agredido em relação ao seu agressor. Isso poderia explicar o fato de quando emitido esse sinal o comportamento dos emissores varie da fuga até a não alteração do comportamento. Lacher (1981) acredita que a origem do chamado de alerta seja o contexto agressivo e que, posteriormente, ele tenha assumido a função de alerta e que assim, poderia ser emitida nos dois contextos ainda hoje.

Em relação ao Tamborilar, embora RNAJ tenha confiança de que foi produzido por mocós, nos intriga o fato de que essa forma de comunicação não é comum a animais de rochedos. Levantou-se, então, a hipótese de que fosse um comportamento remanescente de um passado filogenético da espécie - já que é comum a outros roedores, como os heteromídeos do gênero Dipodomys (exceto em D. agilis, para a qual não se tem certeza se esse comportamento faz parte de seu repertório), Perognathus formosus, $P$. 
inornatus e Microdipodops pallidus (Eisenberg 1963) e à Galea, grupo que já foi considerado irmão do mocó e que tem uma espécie simpátrica a ele na caatinga (Lacher 1981; Quintana 1998). Registramos um som característico do Tamborilar em dois episódios do mesmo tipo: um macho, fugindo de outro macho, para dentro de uma caixa de madeira usada como abrigo no recinto, que teria servido de substrato para o tamborilar. RNAJ entende que esse sinal possa ter feito parte do repertório do mocó, antes de sua especialização ao ambiente rochoso e ter se perdido ao longo do tempo; quando ocorreu uma condição propícia (situação de medo somada a um substrato capaz de gerar som), o comportamento emergiu, ao menos em um indivíduo.

Os chamados de exploração em sua maioria foram emitidos nas sessões de pareamentos, no entanto o Drrr e o Chorinho ocorreram em todas as situações. Associamos a baixa e pequena faixa de frequência do Drrr a seu papel de chamado usado em curta distância, para manter os animais em contato no momento do forrageio sem chamar a atenção de possíveis predadores ou competidores; ainda que não se mantivesse o contato visual, por conta de uma pedra ou uma pequena moita entre os animais, o contato sonoro seria mantido.

O chorinho outra emissão comum a cavídeos (Tabela 9) é produzida dentro do mesmo contexto que encontramos em mocós: os animais vocalizam quando estão explorando o ambiente e forrageando; em capivaras, era emitido no momento em que os animais seriam alimentados pelo tratador (Barros et al 2011).

Ainda dentro do contexto de exploração, encontramos a vocalização que denominamos Có. Esse chamado foi encontrado apenas quando os animais estavam no ambiente de cativeiro e por vezes foi produzido quando ocorria uma leve investida agressiva de um indivíduo para outro e o indivíduo agredido corria emitindo uma sequência de Cós, até se juntar a outros animais que estavam entocados. Ou seja, o contexto nos parece 
envolver busca de contato entre animais do grupo. Quando o có era emitido próximo de situações aparentemente desconfortáveis, como o inicio da interação descrita acima, havia uma leve modulação de frequência ascendente ao final da nota, configurando uma forma intermediária entre cós e chorinho, tal como observado em Cavia (Monticelli 2005). Monticelli também encontrou esse chamado no repertório de $C$. porcellus e o descreveu como um chamado de contato usado na manutenção ou no restabelecimento de proximidade física entre indivíduos. Essa descrição de contexto também se aproxima das nossas impressões quando observamos que o Có era emitido em contexto de forrageio com animais próximos um ao outro.

0 Estalido, uma emissão que aqui também descrevemos como produzida em categoria de exploração, foi apenas ouvida nas sessões de pareamentos. Essa emissão também é encontrada no repertório sonoro de capivaras, (Barros et al 2011) e para esses animais foi descrita como uma vocalização utilizada para que os animais se mantenham próximos no momento do forrageio (coesão do grupo). 0 contexto exploratório que categorizamos para os mocós se da pelo fato de terem sido emitidos dentro do novo ambiente a que eles foram momentaneamente expostos. No entanto, observam-se diferenças entre os chamados descritos para capivaras e mocós. As autoras descrevem o estalido das capivaras como unidades sonoras de duração breve e rítmica. Esse ritmo regular está ausente nas emissões dos mocós.

\section{Tamanho de repertório e vida social}

Já se passaram décadas desde que Peter Marler relacionou a complexidade da vida social primata à riqueza de repertórios acústicos, caracterizada pelo número de sinais e pela presença de formas intermediárias (Marler 1976). Sua sugestão era que espécies de ambientes relativamente abertos, que podiam contar com pistas visuais e contextuais nas interações, e nas quais os indivíduos interagiam proximamente, ou 
aquelas que faziam uso de vocalizações principalmente para comunicação intra-grupo, desenvolveriam repertórios vocais graduados; de forma contrária, espécies de ambientes que oferecem pouca visibilidade, como matas densas, ou que dependeriam de chamados de longa distância para comunicação intra ou inter-grupal, teriam repertórios de formas discretas.

De lá para cá a literatura tem apontado outras variáveis ecológicas e sociais atuantes na seleção de repertórios ricos, em aves e primatas. Dentre elas, estão o tamanho do grupo e a intensidade dos vínculos sociais, avaliada pela quantidade de catação (Fandiño-Mariño 1989; Gros-Louis et al. 2008; McComb \& Semple 2005) e a qualidade e o tipo das interações intra-grupais (Gros-Louis et al. 2008; Macedonia 1993).

Nossa pesquisa vem somar, a esse conjunto, dados de roedores sociais que têm como característica a formação de relações relativamente mais longas entre macho e fêmea após o acasalamento (Kleiman 1974), criando um cenário social diferenciado em relação aos roedores sciurognatas. Dentre os Caviinae, o repertório sonoro da Microcavia australis é o mais simples, constituído por apenas três sinais sonoros e um repertório comportamental também relativamente simples (Rood 1972). A espécie forma grupos sociais com níveis de agressividade reduzidos e o cuidado parental é dividido entre os dois sexos (Taraborelli \& Moreno 2009).

Cavia aperea tem um repertório comportamental amplo, formando sociedades estáveis, marcadas por um sistema de reprodução poliginico. Como dito antes, diferentemente dos mocós, em preás os machos defendem as fêmeas através de encontros agonísticos ritualizados com outros machos (Adrian et al. 2008; Monticelli 2005). Nesse sistema também pode ocorrer a formação de alianças com machos menores subordinados, os chamados machos satélites, que são fundamentais para a defesa de recursos (Monticelli, 2005; Asher et al. 2008). Esses comportamentos complexos que envolvem desde corte a exibições agonisticas ritualizadas são intermediados por uma série de sinais acústicos. 0 repertório acústico, como dito acima, é 
relativamente rico, constituído por 10 sinais sonoros (Berryman 1976; Monticelli \& Ades submetido), metade deles comuns a Kerodon rupestris

Nas capivaras, $H$. hydrochaeris, o repertório comportamental também é rico e o grupo social é composto de um macho dominante e diversas fêmeas, linearmente hierarquizadas. As fêmeas submissas são as que mais amamentam os filhotes do grupo (aloamamentação) (Nogueira et al. 2000). Embora possa ocorrer união temporária entre grupos, em época de escassez de recursos, novos membros não são bem aceitos no grupo quando os recursos são abundantes. Nessa situação, ocorrem ataques e até mortes de indivíduos invasores. Essa estrutura social é também acompanhada por uma série de emissões sonoras (Barros, 2009; Barros et al 2011), como discutido anteriormente e algumas também compartilhadas pelo mocó (Tabela 9).

\section{Conclusão: o mocó e a Caatinga}

A caatinga é popularmente conhecida como um ambiente árduo para a vida. As temperaturas são muito altas, o solo não retém água e o regime de chuvas é escasso e imprevisível (Barbosa et al. 2005; Prado 2005). Essa "ilha de aridez em meio ao trópico mésico" (Leal et al. 2005b, p. 141) presta uma importante contribuição em termos de biodiversidade brasileira, apresenta nível de endemismo que varia entre 3 a 57\% entre espécies da flora e da fauna (Leal et al. 2005a) e representa uma oportunidade única para estudos sobre adaptação de espécies a ambientes xéricos estressantes (Leal et al. 2005b; Prado 2005).

O mocó é a espécie de mamífero mais notória da caatinga pelo seu endemismo. Dentre as 143 espécies de mamíferos que ocorrem por lá, apenas Kerodon rupestris e Wiedomys pyrrhorhinos (um pequeno roedor sciurognata) são exclusivas da caatinga. Outras 17 , a maioria de roedores sciurognatas ou caviomorfos, uma espécie de gambá e uma de macaco sauá, apresentam grande parte da sua área de distribuição na caatinga. Apenas 16 foram classificadas como sendo amplamente distribuídas em outros biomas 
e tendo registros apenas esporádicos na área (o "subconjunto de espécies do Cerrado" de Mares et al. 1985); a grande maioria da espécies distribuí-se amplamente tanto pela caatinga como em outras áreas.

É provável que o mocó seja uma espécie remanescente de uma linhagem evolutiva autóctone, dentro da Teoria dos Refúgios, e que tenha sobrevivido nesse ambiente através da exploração de manchas menos áridas, desde o pleistoceno. (Lessa \& Pessoa 2005; Oliveira et al. 2005; Silva 2011). Esses refúgios (manchas) correspondem aos afloramentos rochosos sob os quais o solo é capaz de reter água (depósitos de água por entre as rochas, proveniente de chuvas ou de condensação da névoa da madrugada,), criando condições para a instalação de espécies vegetais lenhosas frutíferas, que garantem a oferta de alimento mesmo nas épocas mais secas (Barbosa et al. 2005). Esse microclima oferecido pelos afloramentos rochosos da caatinga, permite a ocorrência de vegetação arbórea nesse local, e a coexistência de mocós junto a essas árvores pode ter fornecido a pressão necessária para que esses animais tenham desenvolvidos o hábito escalador forrageando acima no nível do solo, mas sem abandonar o hábito de se alimentar de plantas rasteiras, ampliando o seu repertório alimentar (Willig \& Lacher-Jr 1991). Nesse caso, a especialização ao microhabitat rochoso, também oferta a redução de competição por alimento com outros herbívoros da caatinga, como por exemplo, com Galea spixii.

Além de oferecer fonte de alimentação durante o ano, esses refúgios fornecem proteção contra a extensa lista de predadores existente na caatinga (Campos 2008), proteção contra insolação, bem como um local seguro para a geração e criação de filhotes (Mares 1997).

Para aproveitar esse novo nicho, o mocó teria mudado o hábito pastador dos cavíneos e da capivara, seu grupo irmão na revisão mais recente (Woods \& Kilpatrick 2005), para o hábito de escalar arbustos e rochas, e coletar e se alimentar de folhas e frutos desses arbustos. A favor dessa teoria estão as modificações anatômicas que o mocó compartilha com 
outras espécies de rochedos (rock-dwelling). Animais que se adaptam a viver em formações rochosas entre outras modificações, em geral compartilham aspectos morfológicos (Mares \& Lacher, 1987). Os mocós não apresentam garras em nenhuma das patas e possuem coxins almofadados e pés longos, que facilitam a eles se deslocar pelas rochas, saltar e escalar as árvores, observações salientadas por Lacher (1981) e por nós constatadas em campo. Essas características são também compartilhadas por Heterohirax brucei pertencente a família Procavidae, um pequeno mamífero africano, que além desses caracteres compartilha com os mocós aspectos comportamentais, como a poliginia de defesa de recursos, a formação de haréns (Mares e Lacher 1987).

Entendemos que outra vantagem que as rochas oferecem aos animais a elas adaptados se encaixa ao aspecto de proteção do grupo, é a ocorrência de locais que podem funcionar como postos de observação, visto que em geral, animais que vivem em rochas destacam um ou mais indivíduos que podem exercer a função de sentinela, atento a aproximação de possíveis predadores. Ao menor sinal de perigo emitem a vocalização de alarme, uma adaptação comportamental que Mares \& Lacher (1987) destacam como sendo comum a espécies gregárias de afloramentos rochosos.

Para aproveitar o micro-habitat dos rochedos da caatinga, um recurso concentrado em alguns pontos, é possível que ele tenha sofrido alterações nos seus hábitos sociais e reprodutivos. Segundo Lacher (1981) é provável que o macho monopolize a área de recurso e esta situação pode favorecer a formação de haréns solicitando a tolerância social dentro dessa área e complexidade de comportamentos agressivos para proteger os recursos de intrusos.

E, para acompanhar e regular essa vida social tão complexa, desenvolveu um rico repertorio de sinais capazes de carregar toda a variedade de informações necessária, independente da luz e passível de ser usada à distancia. Esse repertório, contudo, também não é uma novidade 
evolutiva. Em Cavia e em Hydrochoerus, repertórios acústicos amplos acompanham sistemas sociais complexos. Mas, ao que a literatura apontou até agora, o mocó foi além em termos de número de sinais que compõe seu repertório. Levantamos aqui a hipótese de que esse aumento no numero de sinais, especialmente agonisticos, seja decorrente da formação patrilinear que, por sua vez, teria derivado da exploração do novo nicho dos rochedos, sua forma de sobreviver na caatinga. Nossos resultados levantaram muitas questões que buscaremos responder em um trabalho que dará continuidade a este: o que são os silvos, afinal? Há vocalizações exclusivas de filhotes? De que modo essa variedade de sinais que acompanharam interações agonisticas funcionam na regulação do grupo ou na manutenção do território? Quem emite o assobio de alarme e qual o risco real que assume ao fazê-lo?

0 mocó é uma parte importante da história da Caatinga. À medida que entendermos como evoluiu o sistema de comunicação na espécie, através da comparação com outros táxons, teremos uma base mais sólida para discutir sua origem e, consequentemente, a formação do bioma que o deu origem. 


\section{Referências Bibliográficas}

Adrian, O., Kaiser, S., Sachser, N., Jandewertha, P., Löttkera, P., Epplenb, J. T., \& Hennessy, M. B. (2008). Female influences on pair formation, reproduction and male stress responses in a monogamous cavy (galea monasteriensis). Hormones and Behavior 53(3), 403-412.

Arvola, A. (1974). Vocalizations in the guinea pig cavia porcellus I. Annales Zoologic Fennici, 11(1-96).

Asher, M., Lippmann, T., Epplen, J. T., Kraus, C., Trillmich, F., \& Sachser, N. (2008). Large males dominate: Ecology, social organization, and mating system of wild cavies, the ancestors of the guinea pig. Behavioral Ecology and Sociobiology, 62 , 1509-1521.

Asher, M., Oliveira, E. S., \& Sachser, N. (2004). Social system and spatial organization of wild guinea pigs (cavia aperea) in a natural low density population. Journal of Mammalogy, 85(4), 788-796.

Asher, M., \& Sachser, N. (2001). Habitat use and structure of wild guinea pigs under natural conditions. Advances in Ethology, 36(Suppl. to Ethology), 117.

Barbosa, D. C. d. A., Barbosa, M. C. d. A., \& Lima, L. C. M. d. (2005). Fenologia de espécies lenhosas da caatinga. In I. L. Leal, M. Tabarelli \& J. M. C. d. Silva (Eds.), Ecologia e conservação da caatinga (pp. 657-693). Recife: Editora Universitária UFPE.

Barros, K. S. (2009). Repertório sonoro de capivaras: Estrutura acústica e contexto comportamental. Universidade Estadual de Santa Cruz, llhéus.

Barros, K. S., Tokumaru, R. S., Pedroza, J. P., \& Nogueira, S. S. C. (2011). Vocal repertoire of captive capybara (hydrochoerus hydrochaeris): Structure, context and function. Ethology, 117(1), 83-94.

Berryman, J. C. (1976). Guinea pig vocalizations, their structure, causation and function. Zeitschrift für Tierpsychologie, 41, 80-106.

Bezerra, A. M. R. (2008). Revisão taxonômica do gênero galea meyen, 1832 (rodentia, caviidae, caviinae). Unpublished Tese de Doutorado, Universidade de Brasília, Brasília.

Bezerra, A. M. R., Bonvicino, C. R., Menezes, A. A. N., \& Marinho-Filho, J. (2010). Endemic climbing cavy kerodon acrobata (rodentia: Caviidae: Hydrochoerinae) from dry forest patches in the cerrado domain: New data on distribution, natural history, and morphology. Zootaxa, 2724, 29-36.

Campos, C. B. (2008). Carnívoros da caatinga [Electronic Version]. Jornal Tamanduá. Retrieved 27/07/2011 from http://www.fazendatamandua.com.br/jt-mar08.htm. .

Castelletti, C. H. M., Santos, A. M. M., Tabarelli, M., \& Silva, J. M. C. d. (2005). Quanto ainda resta da caatinga? Uma estimativa preliminar. In I. L. Leal, M. Tabarelli \& J. M. C. d. Silva (Eds.), Ecologia e conservação da caatinga (pp. 719-734): Editora Universitária UFPE. 
Cherem, J. J., Olimpio, J., \& Ximenez, A. (1999). Descrição de uma nova espécie do gênero cavia pallas, 1766 (mammalia - caviidae) das ilhas moleques do sul, santa catarina, sul do brasil. Biotemas, 12(1), 95-117.

Cohn, D. W. H., Tokumaru, R. S., \& Ades, C. (2004). The influence of female novelty on courtship behavior of male guinea pigs (cavia porcellus). Brazilian Journal

Dunnum, J. L., \& Salazar-Bravo, J. (2010). Phylogeny, evolution, and systematics of the galea musteloides complex (rodentia: Caviidae). Journal of Mammalogy, 91(1), 243-259.

Eisenberg, J. F. (1963). A comparative study of sandbathing behavior in heteromyid rodents. Behaviour, 22(1-2), 16-23(18).

Eisenberg, J. F. (1974). The function and motivational basis of hystricomorph vocalizations. Symposia of the Zoological Society of London, 34, 211-247.

Fandiño-Mariño, H. (1989). A comunicação sonora do anu-branco guira guira. Avaliações eco-etológicas e evolutivas. Campinas.: Editora Unicamp.

Greenwood, P. J. (1980). Greenwood, pj 1980. Mating systems, philopatry and dispersal in birds and mammals. Anim. Behav. 28:1140-1162. Animal Behaviour, 28, 11401162.

Grier, J. W., \& Burk, T. (1992). Cap 15: Animal communication. In Biology of animal behavior (2 ed.). St Louis: Mosby Year Book.

Gros-Louis, J. J., Perry, S. E., Fichtel, C., Wikberg, E., Gilkenson, H., Wofsy, S., \& Fuentes, A. (2008). Vocal repertoire of cebus capucinus: Acoustic structure, context, and usage. International Journal of Primatology, 29(3), 641-670.

Hailman, J. P., \& Ficken, M. S. (1996). Comparative analysis of vocal repertoires, with reference to chickadees. In D. E. Kroodsma \& E. H. Miller (Eds.), Ecology and evolution of acoustic communication in birds (pp. 136-159). London: Cornell University Press.

Herrera, E. A., \& Macdonald, D. W. (1989). Resource utilization and territoriality in groupliving capybaras (Hydrochoerus hydrochaeris). The Journal of Animal Ecology, 58(2), 667-679.

Herrera, E. A., \& Macdonald, D. W. (1993). Aggression, dominance, and mating success among capybara males (Hydrochaeris hydrochaeris). Behavioral Ecology, 4(2), 114-119.

Hsu, M. J., Chen, L.-M., \& Agoramoorthy, G. (2005). The vocal repertoire of formosan macaques, Macaca cyclopis: Acoustic structure and behavioral context. Zoological Studies, 44(2), 275-294.

Izar, P. (1999). Aspectos de ecologia e comportamento de um grupo de macacos-prego (Cebus apella) em área de mata atlântica, são paulo. Unpublished Tese de doutorado, Universidade de São Paulo, São Paulo.

King, J. A. (1956). Social relations of the domestic guinea-pigs living under semi-natural conditions. Ecology, 37, 221-228.

Kleiman, D. G. (1974). Patterns of behaviour in hystricomorph rodents. Symposia of the Zoological Society of London, 34, 171-209.

Künzl, C., \& Sachser, N. (1999). The endocrinology of domestication: A comparison between the domestic guinea-pig (cavia aperea f. Porcellus) and its wild ancestor, the cavy (cavia aperea). Hormones and Behavior, 35, 28-37. 
Lacher, T. E. (1981). The comparative social behavior of kerodon rupestris and galea spixii and the evolution of behavior in the caviidae. Bulletin of Carnegie Museum Natural History, 17.

Leal, I. L., Tabarelli, M., \& Silva, J. M. C. d. (Eds.). (2005a). Ecologia e conservação da caatinga: Editora Universitária UFPE.

Leal, I. R., Silva, J. M. C. d., Tabarelli, M., \& Lacher-JR, T. E. (2005b). Mudando o curso da conservação da biodiversidade na caatinga do nordeste do brasil. Megadiversidade, 1(1), 139-146.

Lessa, G., \& Pessoa, L. M. (2005). Variação ontogenética e sexual em caracteres cranianos de kerodon rupestris wied, 1820 (rodentia: Caviidae). Arquivo do Museu Nacional do Rio de Janeiro, 63(3), 599 - 618.

Macedonia, J. M. (1993). The vocal repertoire of the ring-tailed lemur (lemur catta) Folia Primatologica, 61, 186-217.

Malange, J. M. (2009). Relações filogenéticas de rodentia: Uma abordagem comportamental. Unpublished Dissertação de Mestrado, Universidade de São Paulo, São Paulo.

Manser, M. B., Madden, J. R., Kunc, H. P., English, S., \& Clutton-Brock, T. (2008). Signals of need in a cooperatively breeding mammal with mobile offspring. Animal Behaviour, 76, 1805-1813.

Mares, M. A., \& Lacher, T. E. (1987). Ecological, morphological, and behavioral convergence in rock-dwelling mammals. Current mammalogy, 1, 307-348.

Mares, M. A., Willig, M. R., \& Lacher, T. E., Jr. (1985). The brazilian caatinga in south american zoogeography: Tropical mammals in a dry region. Journal of Biogeography, 12(1), 57-69.

Marler, P. (1976). Social organization, communication and graded signals: The chimpanzee and the gorilla. In P. Bateson \& R. A. Hinde (Eds.), Growing points in ethology (pp. 239-280). Cambridge, U.K.: Cambridge University Press.

McComb, K., \& Semple, S. (2005). Coevolution of vocal communication and sociality in primates. Biology letters, 1, 381-385.

Mendes, F. D. C., \& Ades, C. (1995). O papel da comunicação vocal na coordenação do espaçamento intragrupal de primatas. . Paper presented at the XIII Encontro Anual de Etologia. Anais de Etologia, Pirassununga.

Mendes, F. D. C., \& Ades, C. (2004). Vocal sequential exchanges and intragroup spacing in the northern muriqui brachyteles arachnoides hypoxanthus. An. Acad. Bras. Ciênc, 76(2), 399-404.

Messias, M. R. (1995). Biologia comportamental de cavia aperea em área aberta no estado de são paulo. Unpublished Master Dissertation, Universidade Estadual de São Paulo, Rio Claro.

Monticelli, P. F. (2000). Aspectos acústicos da domesticação: Os chamados de alerta e de corte do preá cavia aperea e da cobaia cavia porcellus. Unpublished Master Dissertation, Universidade de São Paulo, São Paulo.

Monticelli, P. F. (2005). Comportamento e comunicação acústica em cobaias e preás. . Unpublished Doctorade Thesis, Universidade de São Paulo, São Paulo.

Monticelli, P. F., \& Ades, C. (2003). A case study of allomaternal suckling in a group of captive wild cavies, cavia aperea. Revista de Etologia, 5(Suplemento), 186. 
Monticelli, P. F., \& Ades, C. (2005). Comunicação acústica em cavia (família caviidae): 0 rico repertório e os efeitos da domesticação. Simpósio filogenia e comunicação em roedores hystricognathas. Patrícia f. Monticelli (org). XXIII Encontro Anual de Etologia, Assis, SP.

Monticelli, P. F., \& Ades, C. (2011). Bioacoustics of domestication: Alarm and courtship calls of wild and domestic cavies. Bioacoustics, 20(2), 169-192.

Monticelli, P. F., \& Ades, C. (submetido). The rich acoustic repertoire of a precocious rodent, the wild cavy cavia aperea. Bioacoustics.

Monticelli, P. F., Ades, C., Tokumaru, R. S., \& Constantinov, L. (2003). Motivational and ontogenetical variability in guinea-pig pups distress whistles Paper presented at the XIX International Bioacoustics Congress, Belém, Pará

Monticelli, P. F., Tarallo, R. C. R. B., \& Ades, C. (2009). Is food-anticipation whistle of domestic guinea pigs derived from isolation whistle? Paper presented at the International Bioacoustics Congress, Lisbon.

Moojen, J., Locks, M., \& Langguth, A. (1997). A new species of kerodon cuvier, 1825 from the state of goiás, brazil (mammalia, rodentia, caviidae). . Boletim do Museu Nacional, 377, 1-9.

Nogueira, S. S. d. C., Otta, E., Dias, C. T. d. S., \& Nogueira-Filho, S. L. G. (2000). Alloparental behavior in the capybara (hydrochoerus hydrochaeris). Revista de Etologia, 2(1), 17-22.

Oliveira, D. A. G., \& Ades, C. (2004). Long-distance calls in neotropical primates. Anais da Academia Brasileira de Ciências, 76(2), 1-6.

Oliveira, D. A. G. d. (2002). Vocalizações de longo alcance de alouatta fusca clamitans e alouatta belzebul belzebul: Estrutura e contextos. Unpublished Tese de Doutorado, Universidade de São Paulo, São Paulo.

Oliveira, J. A. d., Gonçalves, P. R., \& Bonvicino, C. R. (2005). Mamíferos da caatinga. In J. M. C. d. S. Marcelo Tabarelli (Ed.), Ecologia e conservação da caatinga (2 ed., pp. 275-336). Recife: Editora Universitária UFPE.

Phillips, C. T., \& Johnston, C. E. (2009). Evolution of acoustic signals in cyprinella: Degree of similarity in sister species. Journal of Fish Biology, 74(1), 120-132.

Prado, D. E. (2005). As caatingas da américa do sul. In I. L. Leal, M. Tabarelli \& J. M. C. d. Silva (Eds.), Ecologia e conservação da caatinga (pp. 3-74): Editora Universitária UFPE.

Quintana, C. A. (1998). Relaciones filogenéticas de roedores caviinae (caviomorpha, caviidae), de américa del sur. Bol. R. Soc. Esp. Hist. Nat. (Sec Biol.), 94 (3-4), 125-134.

Quintana, R. D., Monge, S., \& Malvárez, A. I. (1998). Feeding patterns of capybara Hydrochoeris hydrochaeris (rodentia: Hydrochaeridae) and cattle in non-insular area of the lower delta of the paraná river, argentina. Mammalia, 62(1), 37-52.

Roberts, M., Maliniak, E., \& Deal, M. (2008). The reproductive biology of the rock cavy, Kerodon rupestris, in captivity: A study of reproductive adaptation in a trophic specialist. Mammalia, 48(2).

Rood, J. P. (1972). Ecological and behavioural comparison of three genera of argentine cavies. Animal Behavior Monographs, 5, 1-83. 
Rowe, D. L., \& Honeycutt, R. L. (2002). Phylogenetic relationships, ecological correlates, and molecular evolution within the cavioidea (mammalia, rodentia). Molecular Biology and Evolution, 19(3), 263-277.

Silva, M. L. d. (2011). A dinâmica de expansão e retração de cerrados e caatingas no período quaternário: Uma análise segundo a perspectiva da teoria dos refúgios e redutos florestais. Revista Brasileira de Geografia Física, 1, 57-73.

Slabbekoorn, H., \& Smith, T. B. (2002). Habitat-dependent song divergence in the little greenbul: An analysis of environmental selection pressures on acoustic signals. Evolution, 56(9), 1849-1858.

Sousa, R. A. d. (2006). Caracterização do ritmo de atividade/repouso do mocó (kerodon rupestris). Unpublished Doutorado, Universidade Federal do Rio Grande do Norte, Natal.

Taraborelli, P., \& Moreno, P. (2009). Comparing composition of social groups, mating system and social behaviour in two populations of microcavia australis. Mammalian Biology - Zeitschrift fur Saugetierkunde, 74(1), 15-24.

Toledo, L. F., Garcia, P. C. A., Lingnau, R., \& Haddad, C. F. B. (2007). A new species of sphaenorhynchus (anura; hylidae) from brazil. Zootaxa, 1658, 57-68.

Verderane, M. P. (2010). Socioecologia de macacos-prego (cebus libidinosus) em área de ecótono cerrado/caatinga. Unpublished Doutorado, Universidade de São Paulo, São Paulo.

Vielliard, J. M. E. (1987). Uso da bioacustica na observação de aves. Paper presented at the II Encontro Nacional de Anilhadores de Aves Rio de Janeiro.

Vielliard, J. M. E. (1997). O uso de caracteres bioacústicos para avaliações filogenéticas em aves Anais de Etologia 1593-107.

Vielliard, J. M. E. (2004). A diversidade de sinais e sistemas de comunicação sonora na fauna brasileira. I Seminário Música Ciência Tecnologia Acústica Musical, 1, 145152.

Vielliard, J. M. E., \& Silva, M. L. d. (2011). Bioacústica: Bases teóricas e regras práticas de uso em ornitologia. In F. S. Sandro Von Matter, lury Accordi, Vitor Piacentini e José Flávio Cândido-Jr (Ed.), Ornitologia e conservação: Ciência aplicada, técnicas de pesquisa e levantamento. Rio de Janeiro: Editora Technical Books.

Vielliard, J. M. E., \& Silva, M. L. d. (no prelo). Bioacústica: Bases teóricas e regras práticas de uso em ornitologia. In F. S. Sandro Von Matter, lury Accordi, Vitor Piacentini e José Flávio Cândido-Jr (Ed.), Ornitologia e conservação: Ciência aplicada, técnicas de pesquisa e levantamento. Rio de Janeiro: Editora Technical Books.

Willig, M. R., \& Lacher-Jr, T. E. (1991). Food selection of a tropical mammalian folivore in relation to leaf-nutrient content. Journa of Mammalogy, 72, 314-321.

Woods, \& Kilpatrick. (2005). Infraorder hystricognathi brandt, 1855. In D. E. Wilson \& D. M. Reeder (Eds.), Mammal species of the world. A taxonomic and geographic reference (pp. 1538-1600). Baltmore, Maryland: Johns Hopkins University Press.

Woods, C. A. (1993). Rodentia: Hystricognathi: Caviidae: Caviinae. In D. E. Wilson \& D. M. Reeder (Eds.), Mammal species of the world: A taxonomic and geographic reference (2 ed.). London Smithsonian Institution. 
Ximénez, A. (1980). Notas sobre el genéro cavia pallas con la descripción de cavia magna sp.N. (mammalia-caviidae). Revista Nordestina de Biologia, 3(especial), 145-179. 